MARIA CAROLINA DE AZEVEDO SERPA

Carrapatos e Riquétsias associados a pequenos mamíferos em áreas endêmicas e não endêmicas para Febre Maculosa Brasileira

São Paulo 


\section{Carrapatos e Riquétsias associados a pequenos mamíferos em áreas endêmicas e não endêmicas para Febre Maculosa Brasileira}

Dissertação apresentada ao Programa de PósGraduação em Epidemiologia Experimental Aplicada às Zoonoses da Faculdade de Medicina Veterinária e Zootecnia da Universidade de São Paulo para a obtenção do título de Mestre em Ciências.

\section{Departamento:}

Medicina Veterinária Preventiva e Saúde Animal

Área de concentração:

Epidemiologia Experimental Aplicada às Zoonoses

\section{Orientador:}

Prof. Dr. Marcelo Bahia Labruna

Coorientador:

Dra. Vanessa do Nascimento Ramos

São Paulo 
Autorizo a reprodução parcial ou total desta obra, para fins acadêmicos, desde que citada a fonte.

DADOS INTERNACIONAIS DE CATALOGAÇÃO NA PUBLICAÇÃO

(Biblioteca Virginie Buff D’Ápice da Faculdade de Medicina Veterinária e Zootecnia da Universidade de São Paulo)

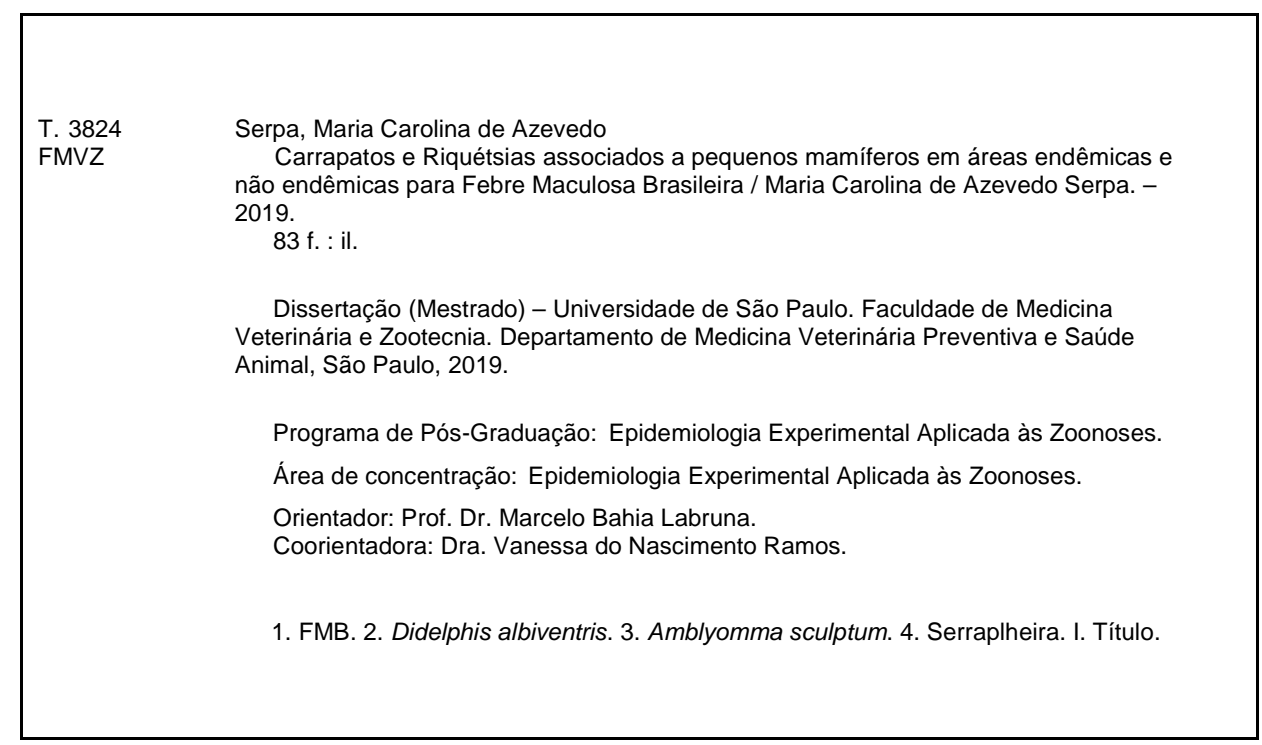

Ficha catalográfica elaborada pela bibliotecária Maria Aparecida Laet, CRB 5673-8, da FMVZ/USP. 


\section{CERTIFICADO}

Certificamos que a proposta intitulada "Pesquisa de Rickettsia spp. transmitidos por carrapatos em pequenos mamíferos e seus carrapatos em áreas endêmicas e não endêmicas para febre maculosa no estado de São Paulo, Brasil.", protocolada sob o CEUA no 6162060317 (ID 003501), sob a responsabilidade de Marcelo Bahia Labruna e equipe; Maria Carolina de Azevedo Serpa - que envolve a produção, manutenção e/ou utilização de animais pertencentes ao filo Chordata, subfilo Vertebrata (exceto o homem), para fins de pesquisa científica ou ensino - está de acordo com os preceitos da Lei 11.794 de 8 de outubro de 2008, com o Decreto 6.899 de 15 de julho de 2009, bem como com as normas editadas pelo Conselho Nacional de Controle da Experimentação Animal (CONCEA), e foi aprovada pela Comissão de Ética no Uso de Animais da Faculdade de Medicina Veterinária e Zootecnia da Universidade de São Paulo (CEUA/FMVZ) na reunião de 06/04/2017.

We certify that the proposal "Survey of tick-borne Rickettsia spp. in small mammals and their ticks in endemic and non-endemic areas for Brazilian spotted fever in the state of São Paulo, Brazil.", utilizing 500 Brazilian wild species (males and females), protocol number CEUA 6162060317 (ID 003501), under the responsibility of Marcelo Bahia Labruna and team; Maria Carolina de Azevedo Serpa - which involves the production, maintenance and/or use of animals belonging to the phylum Chordata, subphylum Vertebrata (except human beings), for scientific research purposes or teaching - is in accordance with Law 11.794 of October 8 , 2008, Decree 6899 of July 15, 2009, as well as with the rules issued by the National Council for Control of Animal Experimentation (CONCEA), and was approved by the Ethic Committee on Animal Use of the School of Veterinary Medicine and Animal Science (University of São Paulo) (CEUA/FMVZ) in the meeting of 04/06/2017.

Finalidade da Proposta: Pesquisa

Vigência da Proposta: de 03/2017 a 02/2019 Área: Medicina Veterinária Preventiva E Saúde Animal

Origem: Não aplicável biotério

Espécie: Espécies silvestres brasileiras $\quad$ sexo: Machos e Fêmeas $\quad$ idade: 60 a 1000 dias $\quad \mathrm{N}: \quad 500$

Linhagem: Não se aplica

Peso: $\quad 30$ a $3000 \mathrm{~g}$

Registro IBAMA/Sisbio/Etc: Licença SISBIO 43259-3

Método de Captura: Em cada uma das seis áreas do estudo, durante três anos consecutivos, capturas de pequenos mamíferos serão realizadas semestralmente, contemplando seis campanhas no total. Em cada campanha, 200 armadilhas do tipo livetrap, como gaiolas e Sherman $\square$ s serão instaladas por cinco noites consecutivas, conforme previamente descrito (Szabó et al. 2013).

Local do experimento: 0 experimento será realizado em seis áreas - ÁREA 1 - Campus 7 Luiz de Queiroz $($ (ESALQ), Piracicaba, SP; ÁREA 2 - Estação de tratamento de esgoto \Cariobal, Americana, SP; - ÁREA 3 \ Campus da Universidade Federal de São Carlos em Araras, SP; - ÁREA 4 \ Campus da Universidade de São Paulo em Pirassununga, SP; - ÁREA 5 प Campus da Universidade de São Paulo em Ribeirão Preto, SP; - ÁREA 6 Parque Estadual Alberto Löfgren (Horto Florestal), São Paulo, SP.

$$
\text { Anneliese Tealar }
$$

Profa. Dra. Anneliese de Souza Traldi Presidente da Comissão de Ética no Uso de Animais Faculdade de Medicina Veterinária e Zootecnia da Universidade Faculdade de Medicina Veterinária e Zootecnia da Universidade de São Paulo

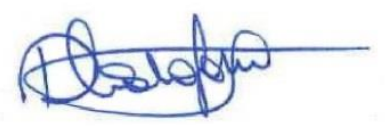

Roseli da Costa Gomes Secretária

de São Paulo 
UNIVERSIDADE DE SÃO PAULO

\section{FACULdADE de MEdicina VeterináRIA E ZOOTECNIA}

Comissão de Ética no Uso de Animais

São Paulo, 22 de julho de 2019

CEUA N 6162060317

IImo(a). Sr(a).

Responsável: Marcelo Bahia Labruna

Área: Medicina Veterinária Preventiva E Saúde Animal

Título da proposta: "Carrapatos e rickettsias associados a pequenos mamíferos de áreas endêmicas e não endêmicas para febre maculosa brasileira".

Parecer Consubstanciado da Comissão de Ética no Uso de Animais FMVZ (ID 004944)

A Comissão de Ética no Uso de Animais da Faculdade de Medicina Veterinária e Zootecnia da Universidade de São Paulo, no cumprimento das suas atribuições, analisou e APROVOU a Alteração do cadastro (versão de 24/junho/2019) da proposta acima referenciada.

Resumo apresentado pelo pesquisador: "Estamos solicitando a mudança do Título da Dissertação de Mestrado da orientada Maria Carolina de Azevedo Serpa de "Pesquisa de Rickettsia spp. transmitidos por carrapatos em pequenos mamíferos e seus carrapatos em áreas endêmicas e não endêmicas para febre maculosa no estado de São Paulo, Brasil." para " Carrapatos e rickettsias associados a pequenos mamíferos de áreas endêmicas e não endêmicas para febre maculosa brasileira". 0 motivo da nossa solicitação foi que, ao término do experimento, concluímos que este outro título seria mais adequado. Gostaríamos de informar que a metodologia inicial proposta não sofreu nenhuma mudança. Ou seja, estamos solicitando apenas a mudança do título da Dissertação. ".

Comentário da CEUA: "Mudança de título aprovada.".

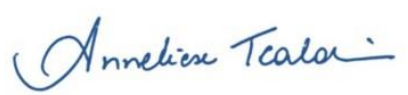

Profa. Dra. Anneliese de Souza Traldi Presidente da Comissão de Ética no Uso de Animais Faculdade de Medicina Veterinária e Zootecnia da Universidade de São Paulo

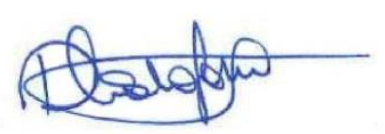

Roseli da Costa Gomes Secretária

Faculdade de Medicina Veterinária e Zootecnia da Universidade de São Paulo 


\section{FOLHA DE AVALIAÇÃO}

Autor: SERPA, Maria Carolina de Azevedo

Título: Carrapatos e Riquétsias associados a pequenos mamíferos em áreas endêmicas e não endêmicas para Febre Maculosa Brasileira

Dissertação apresentada ao Programa de PósGraduação em Epidemiologia Experimental Aplicada às Zoonoses da Faculdade de Medicina Veterinária e Zootecnia da Universidade de São Paulo para obtenção do título de Mestre em Ciências.

Data:

\section{Banca Examinadora}

Prof. Dr.

Instituição: Julgamento:

Prof. Dr.

Instituição: Julgamento:

Prof. Dr.

Instituição: Julgamento: 


\section{DEDICATÓRIA}

Dedico este trabalho ao meu avô Carmelo (in memorian) que sempre disse com orgulho que a neta trabalhava na USP. 


\section{AGRADECIMENTOS}

Agradeço em primeiro lugar a Deus, aos meus pais e minha família por todo apoio sempre, seja qual fosse o caminho por mim escolhido para trilhar.

Ao meu orientador, Marcelo Labruna, pela oportunidade, pelos ensinamentos e pela paciência, sobretudo na fase final do trabalho.

À minha coorientadora Vanessa Ramos por toda a ajuda, dedicação, ensinamentos, parceria, amizade e paciência, por me receber na sua casa e me ajudar tanto na produção desta dissertação, sem ela esse trabalho não teria acontecido.

À Amália por ter me recebido quando era estagiária, por ter me ensinado praticamente tudo da rotina do laboratório, por ter me preparado para a jornada sem fim que seria o mestrado, por todo carinho e amizade que sempre demonstrou por mim.

Ao Xico, Jonas e Alejandro por todos os ensinamentos, por todas as dúvidas tiradas, por toda ajuda, parceria e amizade. Ao Ryan, por ser um amigo com quem sempre pude contar.

À Monize por todo apoio e paciência, cada conversa e cada conselho foi muito importante na construção do que sou hoje.

Às meninas do VPS Lina, Yara, Ana, Jaciara, Mara, Bianca, Bruna, Eve e Bárbara pela amizade e companhia, cada uma a seu modo contribuiu para tornar esse período mais colorido. Ao Hector, Thiago, Seba e Herbert pela ajuda e companheirismo durante os dias de trabalho. Aos amigos que já deixaram o laboratório, mas que contribuíram muito para meu aprendizado Felipe, Marcos, Brisa, Naiani e Sol, e em especial a Marina por estar sempre presente a cada passo que eu dava, me apoiando e torcendo por mim. 
Ao Renato por toda a amizade e ajuda imprescindível, à Hilda por todos os ensinamentos e contribuições, ao Pedrinho, ao Márcio e a todos os funcionários do VPS.

A todas as equipes do Projeto Temático, em especial a de Araras por todo apoio pessoal e logístico durante as coletas desse trabalho.

À FAPESP (processo 2013/18046-7) e à CAPES por todo apoio para realização desse trabalho. 


\section{RESUMO}

SERPA, M.C.A. Carrapatos e Riquetsias associados a pequenos mamíferos de áreas endêmicas e não endêmicas para Febre Maculosa Brasileira. 2019. 83 f. Dissertação (Mestrado em Ciências) - Faculdade de Medicina Veterinária e Zootecnia, Universidade de São Paulo, São Paulo, 2019.

A Febre Maculosa Brasileira (FMB) é a enfermidade transmitida por carrapatos de maior importância médica da América Latina. Capivaras são hospedeiros primários para o carrapato vetor Amblyomma sculptum, e amplificadoras da bactéria Rickettsia rickettsii, causadora da FMB. Entretanto, o ciclo epidemiológico da doença pode envolver outros componentes. Nesse sentido, pequenos mamíferos podem atuar como hospedeiros alternativos para carrapatos e para a manutenção do agente. O objetivo do presente estudo foi comparar ixodofauna e riquétsias associadas a pequenos mamíferos de áreas endêmicas e não endêmicas para FMB. Para isso pequenos mamíferos foram capturados (2015-2018) em três áreas endêmicas (E) e três áreas não endêmicas (NE) com alto grau de antropização no estado de São Paulo, e em duas áreas não endêmicas com baixo grau de antropização (BIO), uma no estado do Mato Grosso e outra no estado do Mato Grosso do Sul. Todos os carrapatos em parasitismo nos pequenos mamíferos capturados foram coletados. Soro sanguíneo foi testado para anticorpos anti-riquétsias por Reação de Imunofluorescência Indireta; carrapatos e tecidos dos pequenos mamíferos tiveram DNA extraído e testado na PCR para Rickettsia. Foi realizada uma análise comparativa de fatores ambientais que pudessem alterar a população de carrapatos e pequenos mamíferos do local entre as áreas E e NE. Foram capturados 629 animais de 27 espécies diferentes. A prevalência de parasitismo nesses animais foi de 45,4\% nas E, 39\% nas NE e 22\% nas BIO. Nas E foram coletados 2795 carrapatos (A. sculptum, Amblyomma dubitatum, Amblyomma ovale e Ixodes loricatus); nas NE 1283 (Ixodes schulzei, I. loricatus, A. ovale, A. sculptum e A. dubitatum) e nas BIO 342 (A.sculptum, Amblyomma parvum, A. ovale, Ornithodoros mimon e I. loricatus). A. sculptum correspondeu a $81 \%$ dos carrapatos nas E, 10,7\% nas NE e 43,8\% nas BIO, ocorrendo majoritariamente no marsupial Didelphis sp. nas E e NE. Foram soropositivos 33,3\% dos roedores e 19,2\% dos marsupiais nas E, $15,7 \%$ e $10,3 \%$ nas $\mathrm{NE}$ e $12,6 \%$ e $11,2 \%$ nas $\mathrm{BIO}$ respectivamente. Nas E a taxa de infecção dos carrapatos testados pela PCR foi de 13,8\%, nas NE 24,1\% e nas BIO 48,6\%. Nenhuma amostra de tecido foi positiva. As áreas NE apresentaram diferenças significativas na variável complexidade de sub-bosque, sendo mais complexo nessas áreas. A composição 
na comunidade de hospedeiros e carrapatos diferiu entre as três áreas estudadas. Evidencia-se maior circulação de riquétsias e maior número de A. sculptum nas E, apesar da similaridade na abundância do principal pequeno mamífero associado a ambos, Didelphis sp., entre as E e NE.

Palavras-chave: FMB, Didelphis albiventris, Amblyomma sculptum, serraplheira 


\begin{abstract}
SERPA, M.C.A. Ticks and rickettsiae associated with mammals of endemic and nonendemic areas for Brazilian spotted fever. 2019. 83 f. Dissertação (Mestrado em Ciências) - Faculdade de Medicina Veterinária e Zootecnia, Universidade de São Paulo, São Paulo, 2019.
\end{abstract}

Brazilian spotted fever (BSF) is the most important vector-borne disease in Latin America. Capybaras are primary hosts for the tick vector Amblyomma sculptum, and amplifiers of the bacterium Rickettsia rickettsii, which causes BSF. However, the epidemiological cycle of the disease may involve other components. In this sense, small mammals can act as alternative hosts for ticks and for the maintenance of the agent. The objective of the present study was to compare ixodofauna and rickettsiae associated to small mammals from endemic and nonendemic areas for BSF. For this purpose, small mammals were caught (2015-2018) in three endemic areas (E) and in three non-endemic (NE) areas with a high degree of anthropogenic impact in the state of São Paulo, and in two non-endemic areas with a low degree of anthropogenic impact (BIO ), one in the state of Mato Grosso and another in the state of Mato Grosso do Sul. All ticks on parasitism in the captured small mammals were collected. Blood serum samples were tested for anti-Rickettsia spp. antibodies by Indirect Immunofluorescence Reaction. Ticks and small mammalian tissues had DNA extracted and tested in PCR for Rickettsia. A comparative analysis of environmental factors that could influence the tick and small mammal populations of the site between $\mathrm{E}$ and NE areas was carried out. We recorded 629 specimens of animals, belonging to 27 small mammal species. The prevalence of parasitism in these animals was $45.4 \%$ in E, 39\% in NE and 22\% in BIO. In the E, 2795 ticks were collected (A. sculptum, Amblyomma dubitatum, Amblyomma ovale and Ixodes loricatus); in NE 1283 ticks (Ixodes schulzei, I. loricatus, A. ovale, A. sculptum and A. dubitatum) and in BIO 342 ticks (A.sculptum, Amblyomma parvum, A. ovale, Ornithodoros mimon and I. loricatus). Amblyomma sculptum corresponded to $81 \%$ of the ticks in the E, $10.7 \%$ in the NE and $43.8 \%$ in the BIO, occurring mainly in the marsupial Didelphis spp. in E and NE. As much as $33.3 \%$ of the rodents and $19.2 \%$ of the marsupials in the E, $15.7 \%$ and $10.3 \%$ in the $\mathrm{NE}$ and $12.6 \%$, and $11.2 \%$ in the BIO, respectively, were seropositive for Rickettsia spp. In the E, the infection rate of the ticks tested by PCR was $13.8 \%$, in $\mathrm{NE} 24.1 \%$ and in $\mathrm{BIO}$ 48.6\%. No vertebrate tissue sample was positive for rickettsiae. The NE areas presented significant differences in the variable sub-forest complexity, being more complex in these 
areas. The composition in the host and tick community differed between the three areas studied. There is evidence of increased circulation of rickettsiae and greater numbers of $A$. sculptum in E, despite the similarity in the abundance of the main small mammal associated with both, Didelphis spp., between E and NE.

Keywords: BSF, Didelphis albiventris, Amblyomma sculptum, litter. 


\section{LISTA DE FIGURAS}

Figura 1 - área de armadilhamento no campus "Luiz de Queiroz”, Piracicaba, SP

Figura 2 - área de armadilhamento na Estação de Tratamento de Esgoto da Carioba, Americana, SP.

Figura 3 - área de armadilhamento no campus da Universidade Federal de São Carlos, Araras, SP.

Figura 4 - área de armadilhamento no campus "Fernando Costa", Lagoa da Captação, Pirassununga, SP.

Figura 5 - área de armadilhamento no campus "Fernando Costa", Lagoa do Risca Faca, Pirassununga, SP. .28

Figura 6 - área de armadilhamento no campus da USP de Ribeirão Preto, Lagoa da Conquista, Ribeirão Preto, SP.

Figura 7 - área de armadilhamento no campus da USP de Ribeirão Preto, Biotério, Ribeirão Preto, SP. 30

Figura 8 - área de armadilhamento no Parque Estadual Alberto Löfgren (Horto Florestal), São Paulo, SP....

Figura 9 - área de armadilhamento na Base Avançada de Pesquisa do Pantanal, Poconé, MT

Figura 10 - área de armadilhamento Pantanal da Nhecolândia, Corumbá, MS

Figura 11 - Etapas de execução do protocolo de PCR para pesquisa de bactérias do gênero Rickettsia em carrapatos e tecidos de pequenos mamíferos capturados em áreas endêmicas e não endêmicas para febre maculosa, entre 2015 e 2018.

Figura 12 - Número de carrapatos coletados sobre pequenos mamíferos nas estações seca e chuvosa em áreas endêmicas (A), não endêmicas com alto grau de antropização (B) e não endêmicas com baixo grau de antropização (C) para FMB, de 2015 a 2018.

Figura 13 - Número de carrapatos A. sculptum (A) e de outras espécies (B) infestando o gambá de orelha branca (D. albiventris) em comparação com os demais pequenos mamíferos (roedores e marsupiais) capturados em áreas endêmicas (E1, E2 e E3), áreas não-endêmicas com alto grau de antropização (NE1, NE2 e NE3) e áreas não-endêmicas com menor grau de antropização (BIO1 e BIO2), de 2015 a 2018. Foram excluídas as larvas identificadas apenas como Amblyomma sp.

Figura 14 - Correlação entre DH de cada localidade e número de carrapatos sobre pequenos mamíferos 


\section{LISTA DE TABELAS}

Tabela 1 - Número de pequenos mamíferos capturados nos três tipos de área (endêmicas e não endêmicas com alto grau de antropização e não endêmicas com baixo grau de antropização) em cada campanha de captura durante o período de 2015 a 2018

Tabela 2 - Prevalências de carrapatos em pequenos mamíferos capturados de 2015 a 2018 nas áreas endêmicas com alto grau de antropização $(\mathrm{E})$, não endêmicas com alto grau de antropização (NE) e não endêmicas com baixo grau de antropização (BIO).

Tabela 3 - Número de carrapatos coletados nos três tipos de área (endêmicas com alto grau de antropização, não endêmicas com alto grau de antropização e não endêmicas com baixo grau de antropização) em cada campanha de captura durante o período de 2015 a 2018.

Tabela 4 - Número total de carrapatos (n) e prevalência (P) em pequenos mamíferos de áreas endêmicas (E) de São Paulo, de 2015 a 2018*.....

Tabela 5 - Número total de carrapatos (n) e prevalência (P) em espécies de pequenos mamíferos infestados em áreas não endêmicas de baixa diversidade (NE) de São Paulo, de 2015 a $2018^{*}$

Tabela 6 - Número total de carrapatos (n) e prevalência $(\mathrm{P})$ em pequenos mamíferos de áreas não-endêmicas de alta diversidade (BIO) nos estados do Mato Grosso e Mato Grosso do Sul, de 2015 a $2018^{*}$

Tabela 7 - Sororreatividade de pequenos mamíferos coletados em áreas endêmicas com alto grau de antropização, não-endêmicas com alto grau de antropização e não-endêmicas com baixo grau de antropização.

Tabela 8 - Infecção por riquétsias em carrapatos coletados em pequenos mamíferos nas áreas endêmicas com alto grau de antropização (E), não endêmicas com alto grau de antropização (NE) e não endêmicas com baixo grau de antropização (BIO) entre 2015 e 2018

Tabela 9 - Variáveis da estrutura do habitat avaliadas nas áreas endêmicas antropizadas (E) e não endêmicas mais antropizadas (NE) do estado de São Paulo, entre 2016 e 2018 .63

Tabela 10 - Déficit hídrico calculado para as áreas E e NE 64 
LISTA DE GRÁFICOS

Gráfico 1 - Diagrama de Whittaker representando riqueza e abundância das espécies de pequenos mamíferos para as áreas de coleta (E, NE e BIO) ..............................................44 


\section{LISTA DE QUADROS}

Quadro1 - Código de Identificação das Áreas Amostradas .25

Quadro 2 - Número de linhas de armadilhas para captura de pequenos mamíferos, montadas em cada área a cada campanha, entre os anos de 2015 e 2018. .34

Quadro 3 - Lista dos primers utilizados nas reações de PCR para pesquisa de bactérias do gênero Rickettsia em carrapatos e tecidos de pequenos mamíferos capturados em áreas endêmicas e não endêmicas para febre maculosa, entre 2015 e 2018 38 


\section{Sumário}

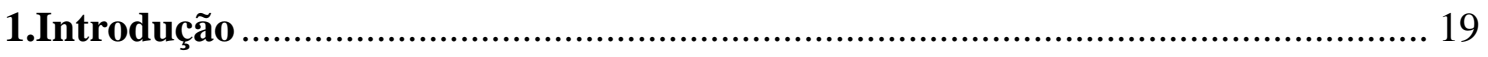

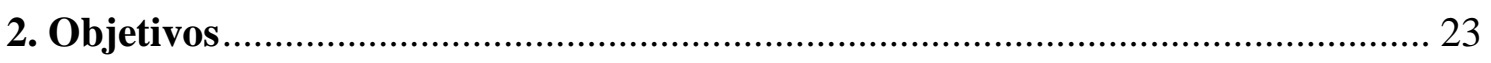

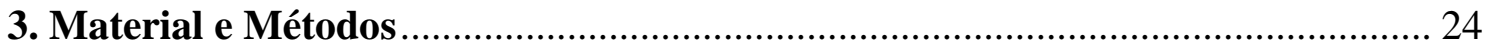

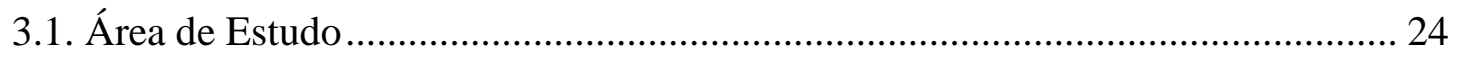

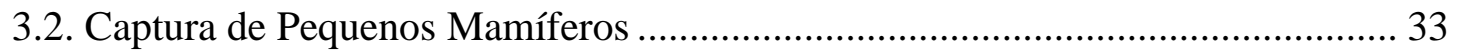

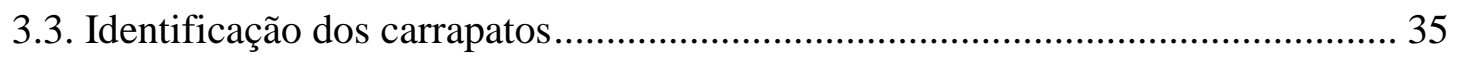

3.4. Sorologia para detecção de anticorpos anti-Rickettsia ....................................... 36

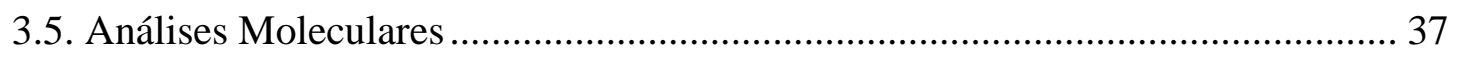

3.6. Sequenciamento de DNA dos Produtos de PCR ................................................... 39

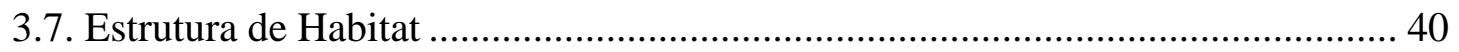

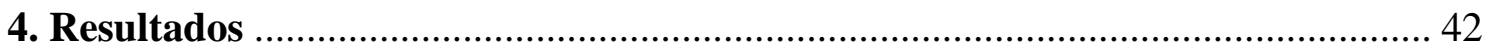

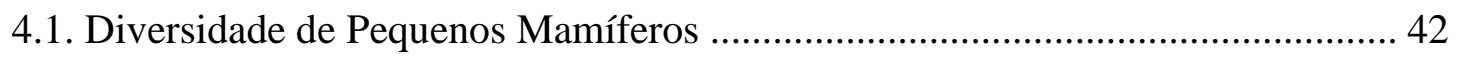

4.2. Diversidade de Carrapatos e Prevalência de Parasitismo ..................................... 45

4.3. Sorologia para detecção de anticorpos anti-Rickettsia......................................... 53

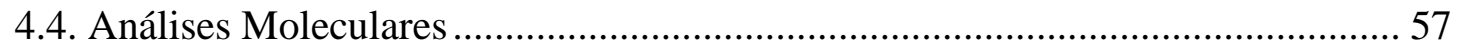

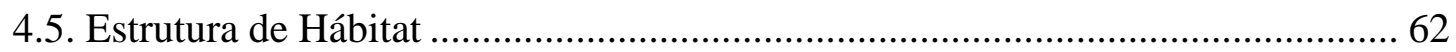

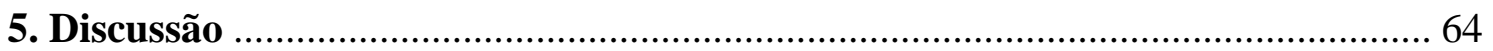

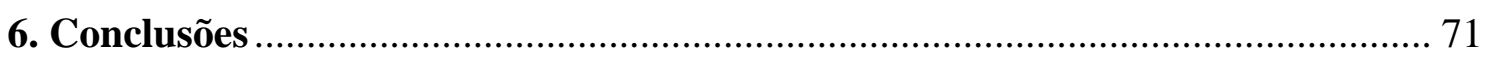

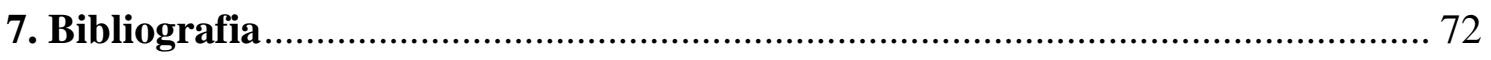




\section{Introdução}

A Febre Maculosa Brasileira (FMB), causada pela bactéria Rickettsia rickettsii, é considerada a doença transmitida por carrapatos de maior importância médica na América Latina (PAROLA et al., 2009), onde tem sua ocorrência confirmada no México, Costa Rica, Panamá, Colômbia, Brasil e Argentina. Os agentes etiológicos da FMB são alphaproteobactérias que pertencem a ordem Rickettsiales, família Rickettsiaceae e ao gênero Rickettsia (RAOULT; ROUX, 1997). São cocobacilos gram-negativos, parasitos intracelulares obrigatórios, que tem tropismo por células endoteliais de pequenos e médios vasos dos hospedeiros vertebrados (HOOGSTRAAL, 1967; WALKER, 1988; EREMEEVA et al., 1998).

Baseado em análises multigênicas, as bactérias do gênero Rickettsia foram divididas em cinco grupos sugeridos por Weinert e colaboradores (2009), sendo: 1) grupo do tifo (GT) em que estão inseridas as espécies Rickettsia prowazekii e Rickettsia typhi;2) grupo da febre maculosa (GFM) composto por mais de vinte espécies; 3) grupo de transição (GTr) em que estão inseridas Rickettsia akari, Rickettsia felis e Rickettsia australis; 4) grupo canadensis (GC) representado pela Rickettsia canadensis; e 5) grupo bellii composto pela espécie Rickettsia belli e outros genótipos encontrados em insetos. A bactéria $R$. rickettsii, inserida no GFM, é a espécie de riquétsia mais patogênica e o agente causador da FMB (LABRUNA, 2009).

O principal vetor da FMB na América Latina é a espécie de carrapato Amblyomma sculptum, antes descrito como Amblyomma cajennense (LABRUNA, 2009; NAVA et al., 2014). Além deste, outras espécies de carrapato desempenham o papel de vetores em ciclos específicos, como por exemplo, Amblyomma aureolatum na região metropolitana de São Paulo (PINTER; LABRUNA, 2006; OGRZEWALSKA et al. 2012); e Rhipicephalus sanguineus sensu lato (s.1.) na região norte do México (PAROLA et al., 2009). Além disso, $R$. sanguineus é considerado um vetor suspeito em áreas endêmicas para FMB, onde a alta densidade de cães e carrapatos, a presença da bactéria causadora, e a proximidade com humanos poderia ocasionar a transmissão acidental da doença (MORAES-FILHO et.al., 2009; LABRUNA, 2009; SZABÓ; PINTER; LABRUNA, 2013).

O carrapato A. sculptum, popularmente chamado de "carrapato estrela", pertence a um complexo de, pelo menos, seis espécies que anteriormente eram todas denominadas como " $A$. 
cajennense”, e que possui ampla distribuição englobando desde o sul dos Estados Unidos até o norte da Argentina. Diferenças morfológicas, geográficas e genéticas possibilitaram a divisão das espécies pertencentes a esse táxon (BEATI et al., 2013; NAVA et al., 2014). Além de A. sculptum, outra espécie deste complexo, denominada, Amblyomma cajennense senso stricto (s.s.), é descrita no Brasil com distribuição no bioma Amazônico nos estados do Pará, Rondônia, Tocantins, Maranhão e Mato Grosso (MARTINS et al., 2016; COSTA et al., 2017).

A distribuição de A. sculptum no território brasileiro abrange originalmente todo o bioma Cerrado, o Pantanal e boa parte das áreas de Mata Atlântica. Vale ressaltar a capacidade de adaptação deste carrapato a áreas de Mata Atlântica degradada, sendo inclusive encontrados em grandes quantidades quase que exclusivamente nesses fragmentos mais antropizados (SZABÓ et al., 2009; MARTINS et al., 2016), fazendo com que sua distribuição aumente à medida em que áreas remanescentes sejam modificadas pelo homem.

Além disso, a presença de A. sculptum está muito relacionada às áreas de mata ciliar em ambientes antropizados, o que propicia o contato deste carrapato com seres humanos, uma vez que esses locais são bastante frequentados, e com as capivaras, um de seus principais hospedeiros (SOUZA et al., 2006; SZABÓ; PINTER; LABRUNA, 2013).

Capivaras (Hydrochoerus hydrochaeris), antas (Tapirus terrestres) e equinos são os principais hospedeiros primários para todas as fases de vida de A. sculptum, o que faz com que a presença e estabelecimento desta espécie de carrapato em determinado local esteja intimamente relacionada com a presença constante de pelo menos uma dessas espécies de mamíferos (LABRUNA, 2013). Nas áreas endêmicas para FMB no estado de São Paulo, em que A. sculptum é o vetor, as capivaras são os principais hospedeiros desse ectoparasita nas áreas de transmissão (HORTA et al., 2007; LABRUNA et al., 2009; BRITES-NETO et al., 2013; LABRUNA, 2013).

Além de manter as populações do carrapato transmissor da FMB, as capivaras são consideradas hospedeiros amplificadores de $R$. rickettsii, pois a mantém em sua circulação sanguínea durante sete a dez dias, período em que é capaz de infectar novos carrapatos que se alimentem nesse animal (SOUZA et al., 2009). Assim, a capivara tem papel de extrema importância no ciclo de transmissão da FMB infectando novas populações de carrapatos. Isso porque o carrapato A. sculptum não mantém a infecção pela bactéria de forma eficiente em 
gerações consecutivas, já que a sua transmissão transovariana e transestadial fica abaixo dos 50\% (LABRUNA, 2009; SOARES et al., 2012; LABRUNA, 2013).

Pequenos roedores e marsupiais silvestres são hospedeiros de numerosas espécies de carrapatos em algum dos estágios (larva, ninfa ou adulto) de seu ciclo de vida (HORAK et al. 2002). No Brasil pequenos mamíferos silvestres são hospedeiros para fases imaturas de carrapatos transmissores de riquetsioses, como A. aureolatum e Amblyomma ovale (GUGLIEMONE et al., 2003; SARAIVA et al., 2012; SZABÓ et al., 2013).

O papel dos pequenos mamíferos silvestres no ciclo epidemiológico da FMB não está totalmente elucidado, mas sabe-se que gambás de orelha preta (Didelphis aurita) infectados experimentalmente em laboratório são capazes de desenvolver riquetsemia por longos períodos (chegando até 30 dias), podendo atuar como hospedeiros amplificadores. Porém, sabe-se também que apenas $5 \%$ dos carrapatos que se alimentam nos gambás nesse período se infectam, fazendo com que esses marsupiais possam ter alguma importância no ciclo de transmissão da doença, desde que se comportem como hospedeiros importantes para A. sculptum nas áreas endêmicas (HORTA et al., 2009).

$\mathrm{Na}$ América Latina, os primeiros registros de casos de FMB datam do final da década de 20 na cidade de São Paulo, quando a afecção era inicialmente denominada "Tipho Exanthemático de São Paulo" (PIZA et al., 1932). Durante a década de 30, pontos importantes do ciclo epidemiológico da doença foram demonstrados através de trabalhos realizados nesse período como, por exemplo, a infecção experimental de A. cajennense com o agente etiológico da FMB através de alimentação em cobaia também experimentalmente infectada (LEMOS-MONTEIRO et al., 1932); a comprovação da transmissão transestadial e vertical da bactéria pelo mesmo carrapato (LEMOS-MONTEIRO; FONSECA, 1932); e o isolamento em cobaia do agente etiológico a partir de um espécime de A. aureolatum (GOMES, 1933).

Após os primeiros relatos da doença e as primeiras elucidações sobre o ciclo de transmissão, houve um período de registros de casos em áreas rurais de municípios vizinhos à capital paulista como Diadema, Santo André e Mogi das Cruzes, porém os dados sobre esses eventos não são precisos (TIRIBA, 1972; TIRIBA; MONTEIRO, 1985; ROSENTHAL, 1989). A contar da década de 80, municípios da região de Campinas começaram a relatar casos de FMB de forma endêmica (LIMA et al., 1995; LIMA et al., 2003) e, após a virada do 
século, a doença vem ocorrendo de forma endêmica na região metropolitana de São Paulo (OGRZEWALSKA et al., 2012).

No Brasil foram registrados 1574 casos de febre maculosa, com confirmação laboratorial, entre os anos de 2007 e 2017 que resultaram em 534 óbitos, ocasionando uma taxa de letalidade de 33,9\%. A Região Sudeste registrou, neste mesmo período, a grande maioria desses casos com 1128 confirmações da doença, em que 528 destes evoluíram para óbito, resultando em uma taxa de letalidade de 46,8\% (BRASIL, 2019).

O estado de São Paulo é a unidade federativa que mais registra casos de FMB. Durante os anos de 2007 até 2019 foram 814 casos confirmados, com 434 óbitos pela doença (letalidade de 54,5\%). Durante este período as cidades que mais notificaram casos no estado foram Campinas $(n=78)$, Piracicaba $(n=62)$, Valinhos $(n=47)$, Santa Bárbara D'Oeste $(n=32)$ e Americana $(n=28)$ no interior do estado; e Santo André $(n=34)$, São Bernardo do Campo ( $n=28)$ e São Paulo $(n=20)$ na região metropolitana. Esses números fazem da FMB, dentre as zoonoses transmitidas por vetores, a que mais mata pessoas no estado de São Paulo (São Paulo, 2019).

Diante desses dados e dada a importância dos carrapatos na transmissão de doenças para humanos e animais, estes parasitos estão entre os mais pesquisados em todo o mundo, porém com uma clara concentração de pesquisas no hemisfério Norte, especialmente nos Estados unidos e Europa. Por esta razão, a lista mundial de patógenos transmitidos por carrapatos contempla poucos agentes de ocorrência reconhecida na América do Sul (DE LA FUENTE et al., 2008; LABRUNA et al., 2011).

Além disso, sabe-se que marsupiais desenvolvem riquetsemia e podem infectar carrapatos mesmo que em menor número quando comparados a outros hospedeiros amplificadores. Porém, não existem dados semelhantes sobre pequenos roedores e também sobre a importância desses mamíferos para manutenção do ciclo de transmissão da FMB. Neste contexto, o presente trabalho foi formulado visando contribuir com informações relativas ao papel dos pequenos mamíferos associados aos carrapatos e as rickettsioses transmitidas por estes em áreas dos estados de São Paulo, Mato Grosso e Mato Grosso de Sul. 


\section{Objetivos}

O objetivo geral do presente trabalho foi verificar as ocorrências de carrapatos e Rickettsia spp, transmitidas por carrapatos em pequenos mamíferos, em seis áreas no estado de São Paulo e duas no Pantanal. Como objetivos específicos, pretendeu-se:

- Avaliar a comunidade de pequenos mamíferos (roedores e marsupiais) em áreas endêmicas e não endêmicas para febre maculosa, incluindo áreas antropizadas e ecossistemas naturais, e verificar o papel desses animais como hospedeiros para carrapatos A. sculptum.

- Identificar as espécies de carrapatos infestando esses pequenos mamíferos;

- Investigar a circulação de $R$. rickettsii nas diferentes espécies de pequenos mamíferos presentes nas diferentes áreas, assim como nos carrapatos parasitando esses animais;

- Correlacionar as espécies de carrapatos com as riquétsias encontradas, e com as características ecológicas de cada área, sobretudo a composição faunística. 


\section{Material e Métodos}

\section{1. Área de Estudo}

O projeto foi realizado de junho/2015 a setembro/2018 em oito áreas distintas com ou sem a ocorrência de casos de FMB, todas com presença de capivaras e de carrapatos vetores. Essas áreas foram classificadas como mais ou menos antropizadas de acordo com o grau de alteração do ambiente causado por ação humana, e divididas da seguinte forma:

- Áreas endêmicas antropizadas (E): todas situadas no estado de São Paulo e com ocorrência constante de casos de FMB e óbitos pela doença, compreendendo o campus "Luiz de Queiroz" (ESALQ) da Universidade de São Paulo (USP) em Piracicaba , a Estação de Tratamento de Esgoto da Carioba em Americana e o Campus da Universidade Federal de São Carlos (UFSCAR) em Araras;

- Áreas não endêmicas com alto grau de antropização (NE): todas situadas no estado de São Paulo sem qualquer casos confirmado de FMB, compreendendo o Campus da USP em Pirassununga, o Campus da USP em Ribeirão Preto e o Parque Estadual Alberto Löfgren (Horto Florestal) na cidade de São Paulo;

- Áreas não endêmicas com baixo grau de antropização (BIO) sem ocorrência de casos de FMB e sem evidência de circulação da bactéria causadora da afecção compreendendo o Pantanal de Poconé, em Poconé, estado do Mato Grosso e o Pantanal da Nhecolândia, em Corumbá, estado do Mato Grosso do Sul.

Além dos critérios de ocorrência dos casos de FMB também foram levados em consideração critérios como logística e apoio técnico para realização do trabalho em cada local. Cada área recebeu um código de identificação discriminado no Quadro 1: 
Quadro1: Código de Identificação das Áreas Amostradas

\begin{tabular}{|lc|}
\hline \multicolumn{1}{|c|}{ Área } & Código da Área \\
\hline ESALQ (USP) - Piracicaba/SP & E1 \\
Estação de Tratamento de Esgoto da Carioba - Americana/SP & E2 \\
UFSCAR - Araras/SP & E3 \\
\hline USP - Pirassununga/SP & NE1 \\
USP - Ribeirão Preto/SP & NE2 \\
Parque Estadual Alberto Löfgren - São Paulo/SP & NE3 \\
\hline Pantanal de Poconé - Poconé/MT & BIO1 \\
Pantanal da Nhecolândia - Corumbá/MS & BIO2 \\
\hline
\end{tabular}

O campus "Luiz de Queiroz" (ESALQ) da Universidade de São Paulo (USP), situado na cidade de Piracicaba, no centro do estado de São Paulo, possui cerca de 915 hectares divididos entre área construída, cultivo, pastagens, locais de mata primária e secundária, além de cursos de água como do Rio Piracicaba que margeia o campus (MARCHINI; FERRAZ, 2014; ESALQ, 2019). A cidade é reconhecidamente uma área endêmica para FMB registrando 59 casos da doença entre 2007 e 2018, sendo a segunda cidade com maior número de casos no Estado (SÃO PAULO, 2019). A figura 1 mostra a área onde foram colocadas as linhas de armadilha nesse local.

Figura 1: área de armadilhamento no campus "Luiz de Queiroz", Piracicaba, SP

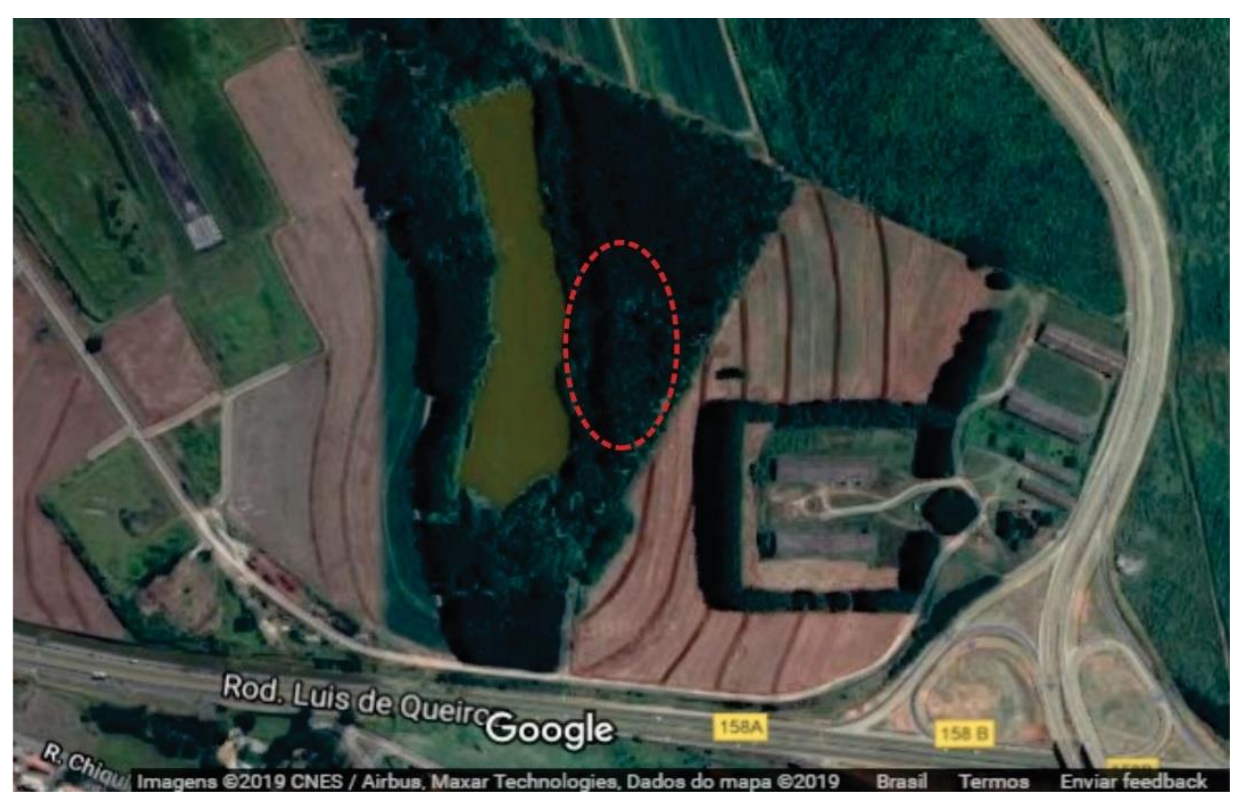

Google, 2019 
A Estação de Tratamento de Esgoto da Carioba está localizada no município de Americana, região de Campinas, ao leste do Estado de São Paulo, e tem sua área delimitada pelas margens do Rio Piracicaba e do Ribeirão Colombo, e pela linha férrea América Latina Logística - ALL. A estação é responsável pelo tratamento de cerca de $70 \%$ do esgoto sanitário da cidade (AMERICANA, 2019). Americana também é considerada uma área endêmica para FMB com 28 casos confirmados entre 2007 e 2018, e 11 óbitos pela doença só em 2018 (SÃO PAULO, 2019). A figura 2 mostra a área onde foram colocadas as linhas de armadilha nesse local.

Figura 2: área de armadilhamento na Estação de Tratamento de Esgoto da Carioba, Americana, SP

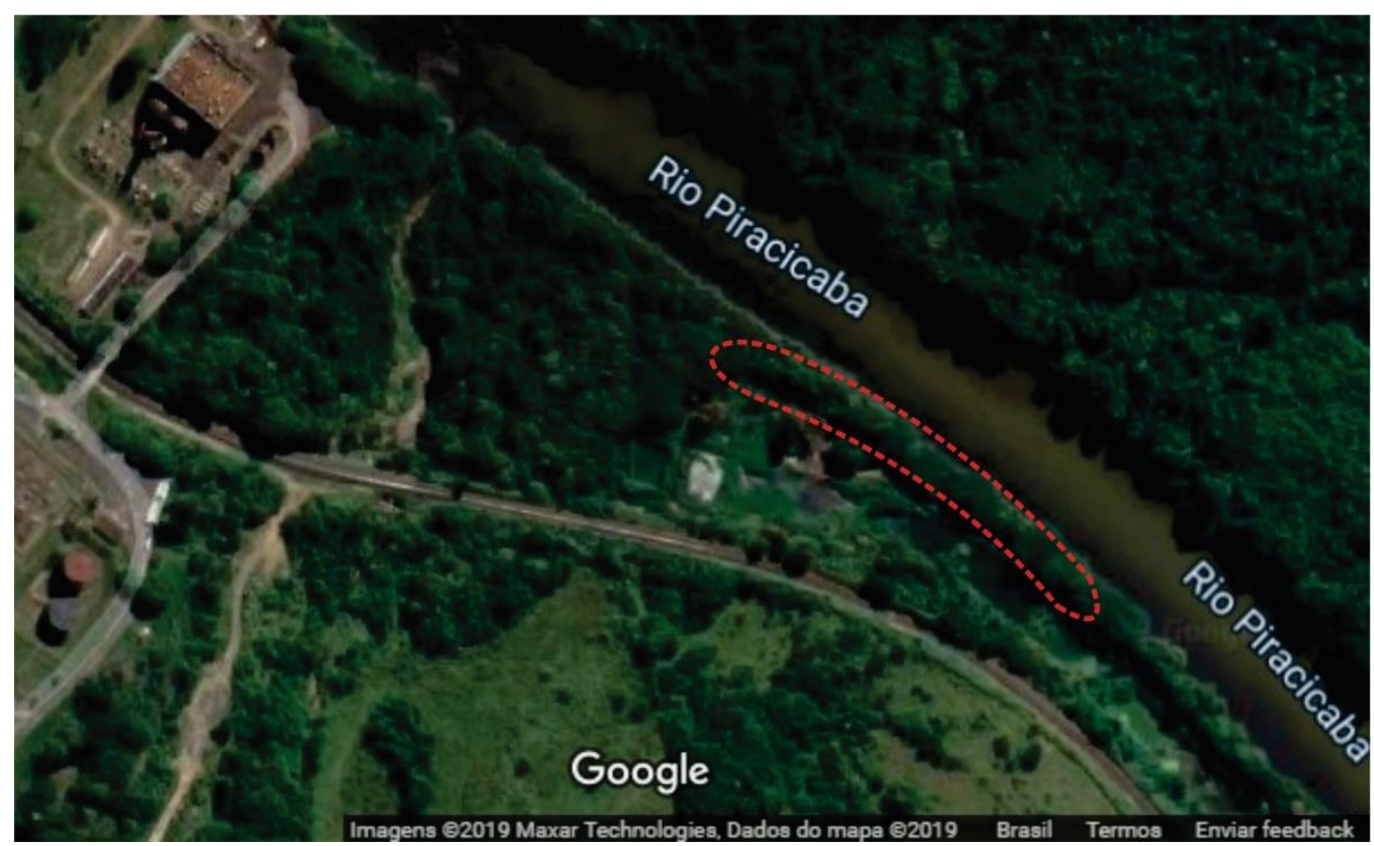

Google, 2019

O campus da Universidade Federal de São Carlos, na cidade de Araras, possui 230 hectares, sendo mais da metade constituído de área de cultivo experimental de cana-deaçúcar; o restante do campus é formado de uma pequena área construída, três lagos, pastos e áreas de mata secundária (ROCHA et. Al, 2017). A cidade está localizada ao centro-norte do estado de São Paulo e registrou 20 casos de FMB entre 2007 e 2018 (SÃO PAULO, 2019). A figura 3 mostra a área onde foram colocadas as linhas de armadilha nesse local. 
Figura 3: área de armadilhamento no campus da Universidade Federal de São Carlos, Araras, SP

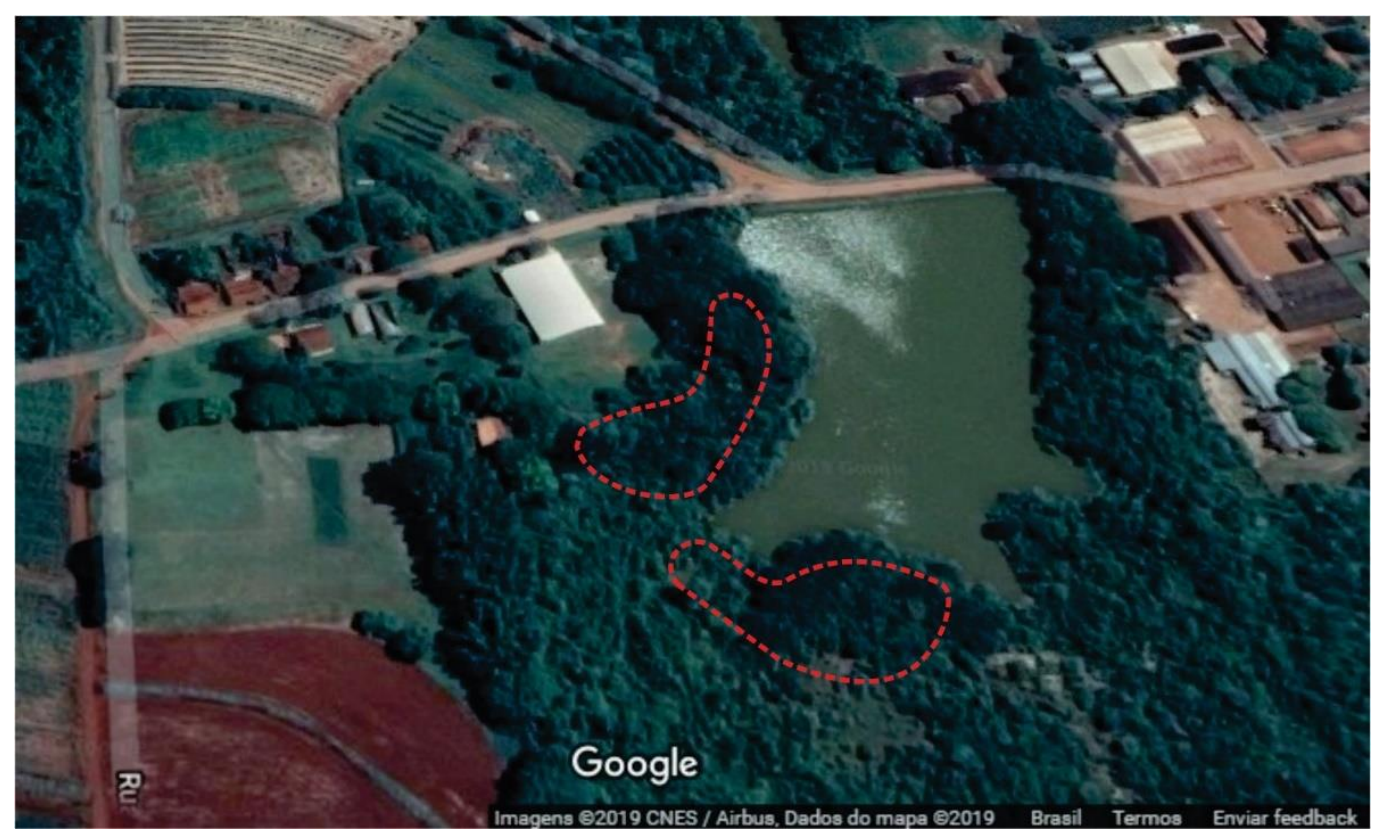

Google, 2019

O campus "Fernando Costa", da USP de Pirassununga, situado na cidade de mesmo nome, possui cerca de 2200 hectares de área, desse total 1000 hectares são destinados a pastagens, 300 hectares para área de cultivo e o restante é dividido em área construída, reservas florestais com mata secundária, além de represas e um sistema de captação de água (FZEA, 2015). Também localizada ao centro-norte do estado de São Paulo, Pirassununga nunca registrou casos de FMB (SÃO PAULO, 2019). As figuras 4 e 5 mostram as áreas onde foram colocadas as linhas de armadilhas nesse local. 
Figura 4: área de armadilhamento no campus "Fernando Costa", Lagoa da Captação, Pirassununga, SP

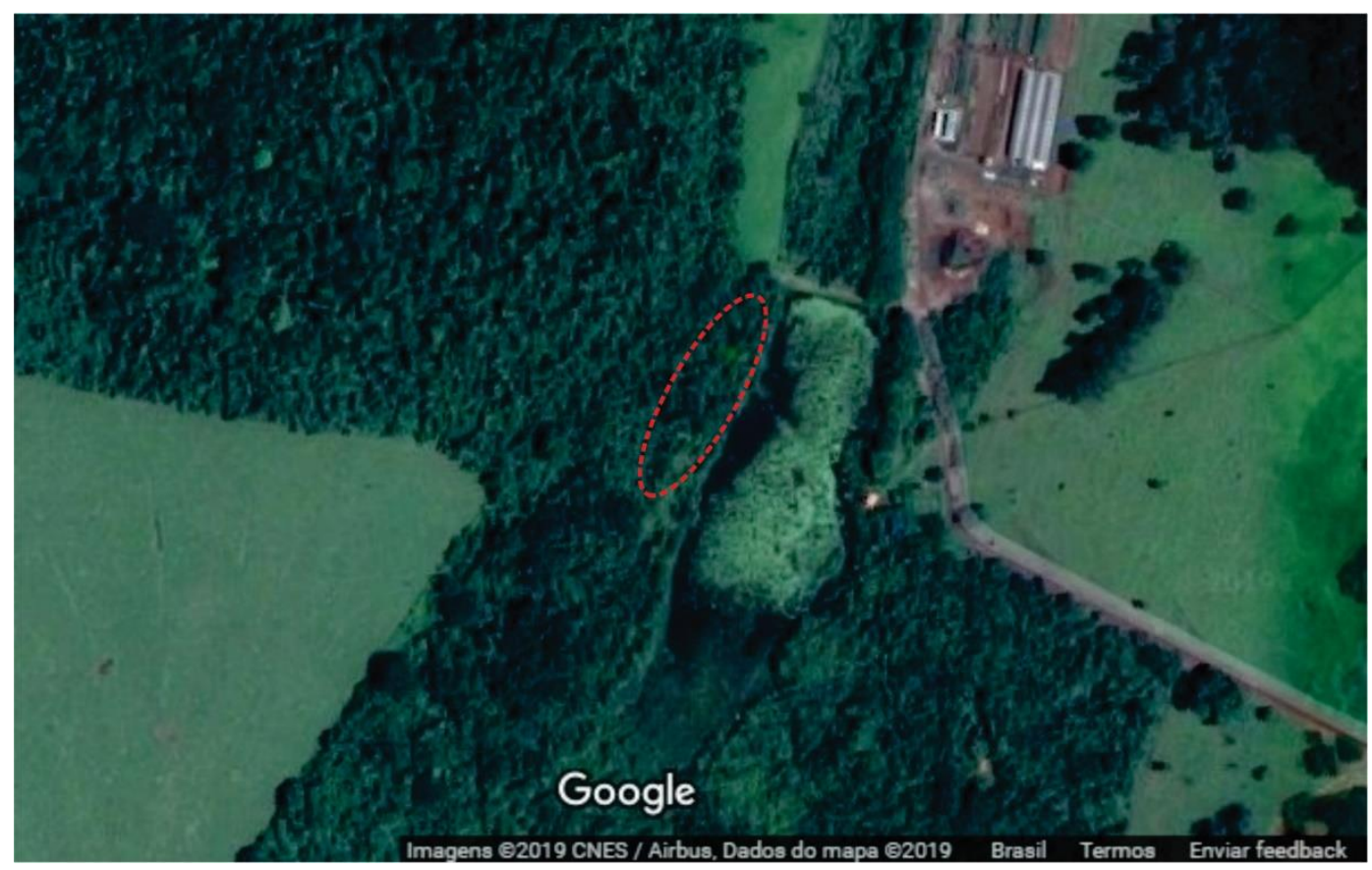

Google 2019

Figura 5: área de armadilhamento no campus "Fernando Costa", Lagoa do Risca Faca, Pirassununga, SP

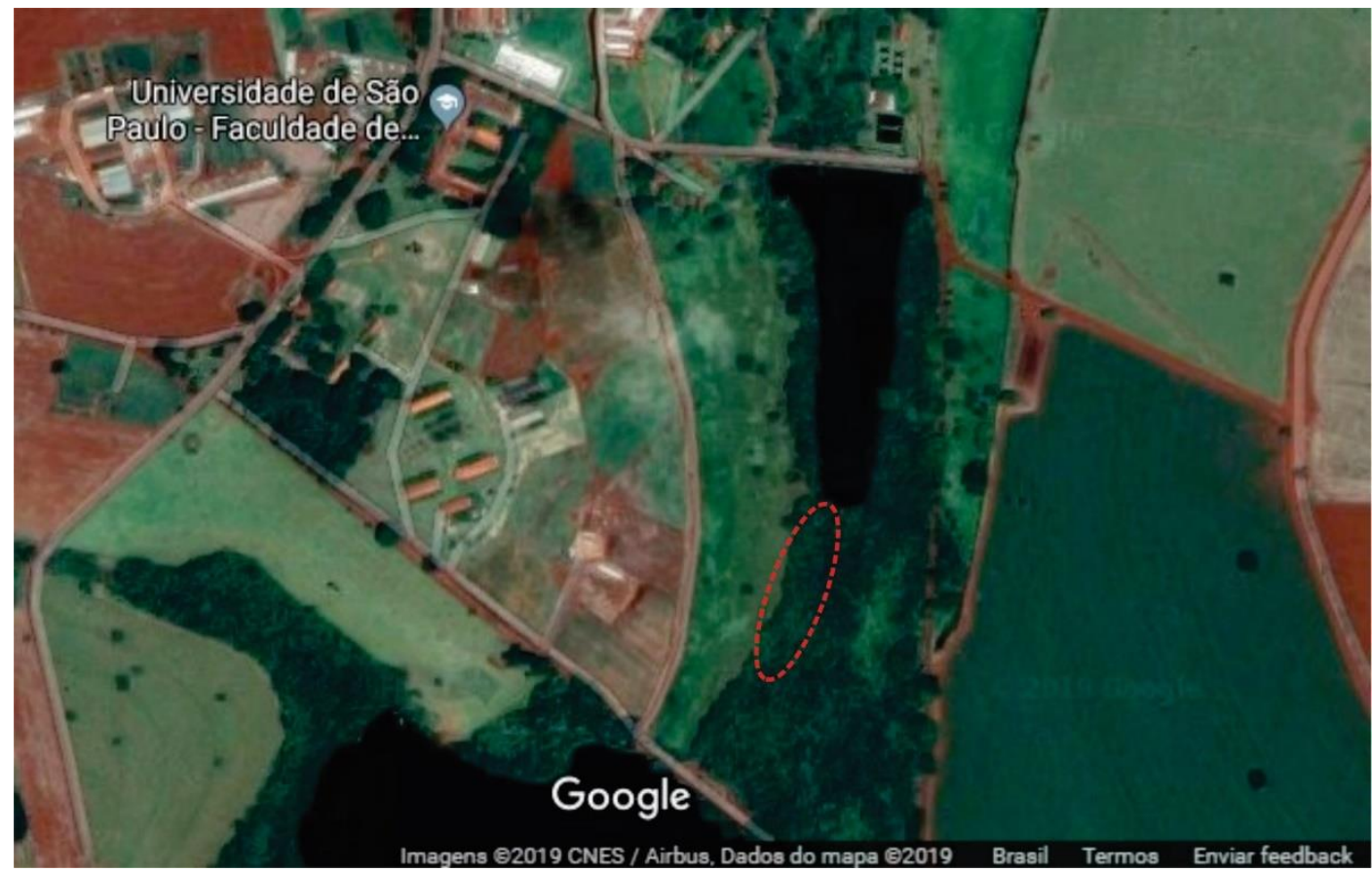

Google, 2019 
O campus da USP na cidade de Ribeirão Preto tem uma área total de 586 hectares, e destes, 470 hectares são de área de mata secundária e o restante do campus, de área construída, além de represas e lagos (FEA-RP, 2012). O município registrou dois casos de FMB no período de 2007 a 2018, ambos no ano de 2011, sem que nenhum evoluísse para óbito (SÃO PAULO, 2019), porém, nenhum desses casos esteve relacionado ao campus da USP naquele município, que pelo contrário, foi considerado como área não endêmica para FMB (M.B. Labruna, comunicação pessoal). As figuras 6 e 7 mostram as áreas onde foram colocadas as linhas de armadilhas nesse local.

Figura 6: área de armadilhamento no campus da USP de Ribeirão Preto, Lagoa da Conquista, Ribeirão Preto, SP

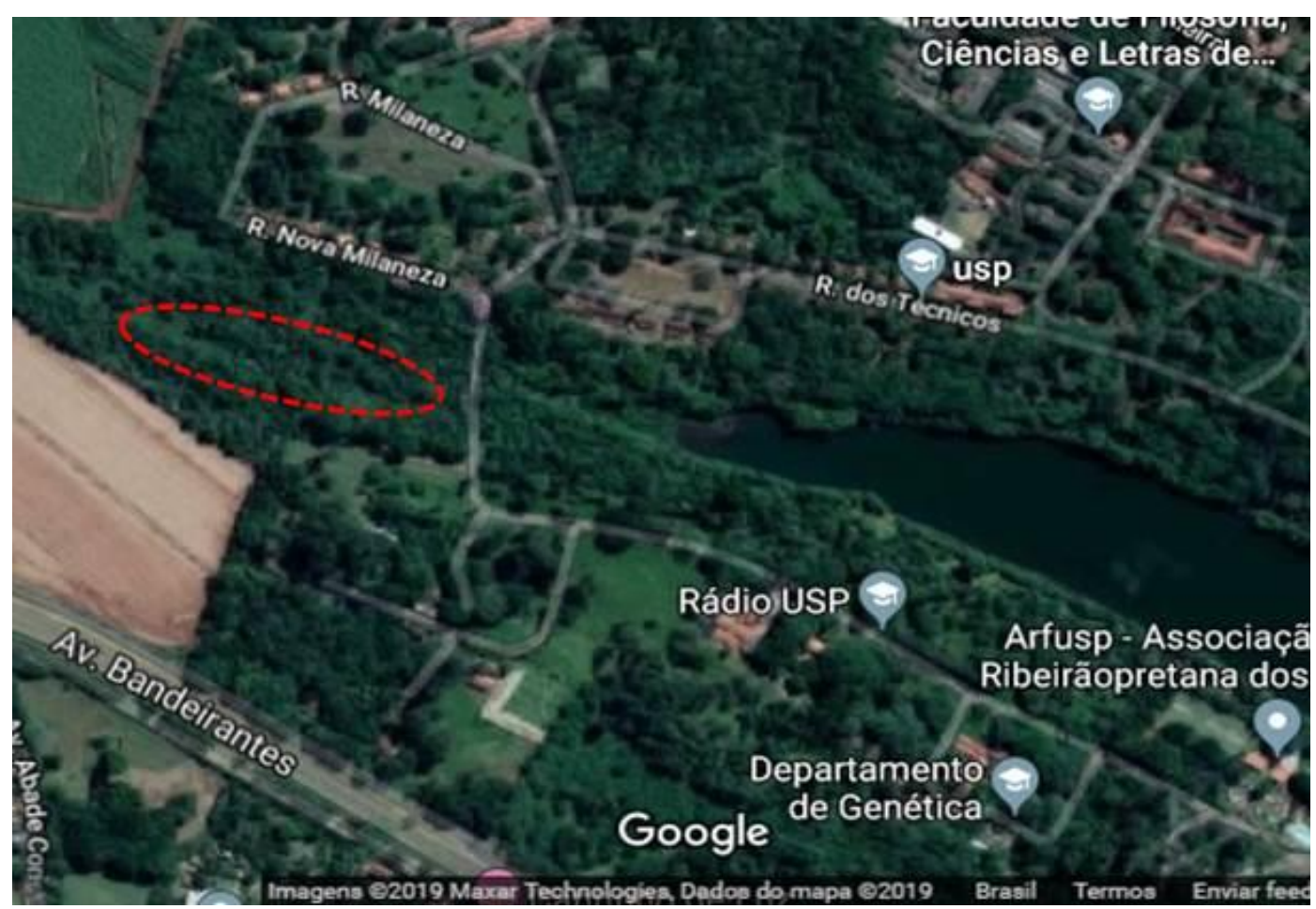

Google, 2019 
Figura 7: área de armadilhamento no campus da USP de Ribeirão Preto, Biotério, Ribeirão Preto, SP

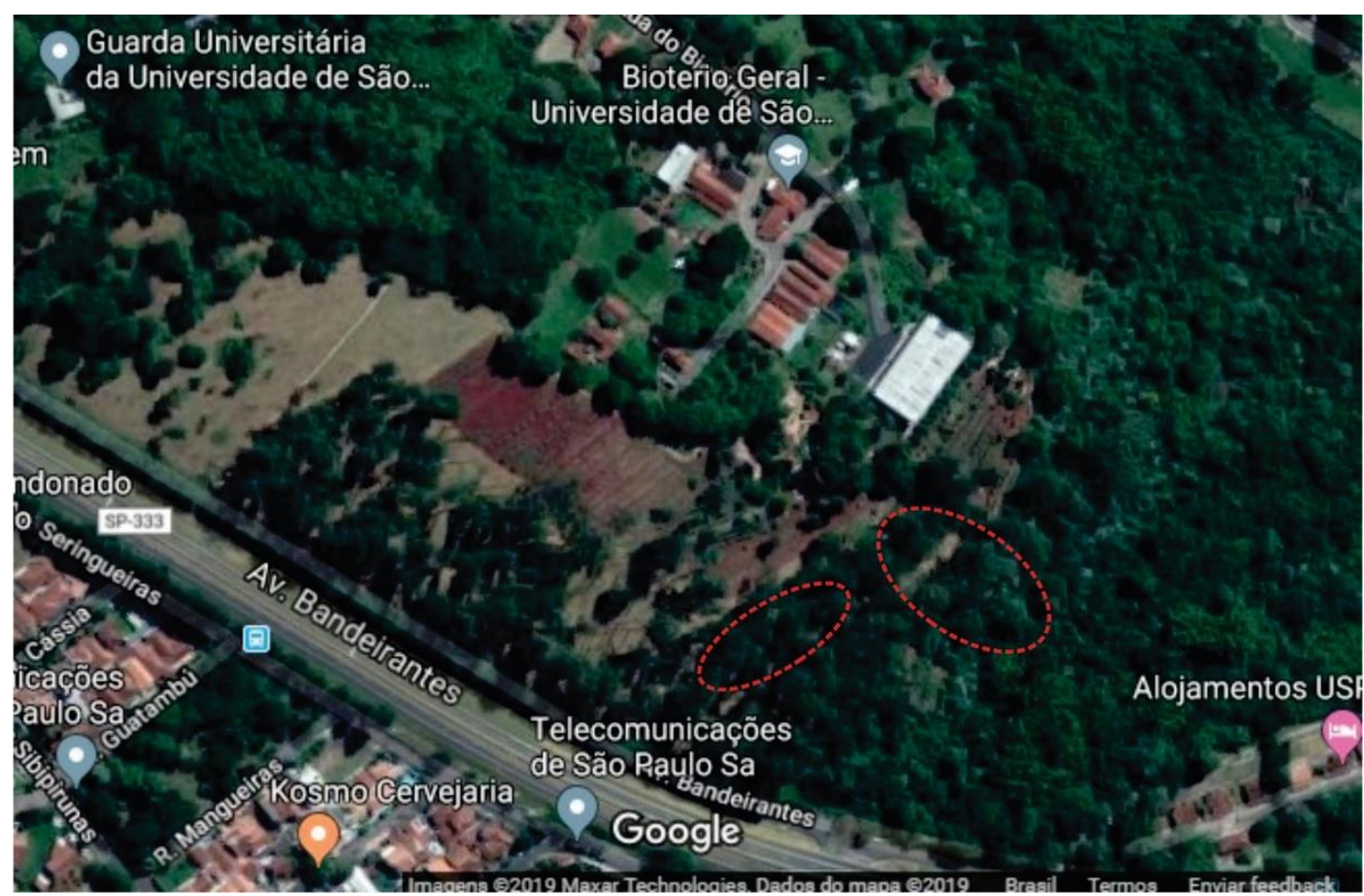

Google, 2019

O Parque Estadual Alberto Löfgren (Horto Florestal) é uma Área de Preservação Permanente (APP), situa-se na zona norte da cidade de São Paulo e possui 187 hectares, sendo174 hectares de mata, incluindo áreas remanescentes de Mata Atlântica Existem no local lagos que são abastecidos por córregos pertencentes às microbacias da região como, por exemplo, da microbacia da Pedra Branca (INSTITUTO FLORESTAL DE SÃO PAULO, 2018). A cidade de São Paulo registrou 21 casos confirmados de FMB entre 2007 e 2018 (SÃO PAULO, 2019), contudo a região norte, em que está inserido o parque, é considerada não endêmica para a doença, uma vez que não existem evidências da circulação do agente causador, $R$. rickettsii, no local (OGRZEWALSKA et. Al, 2012). A figura 8 mostra a área onde foram colocadas as linhas de armadilha nesse local. 
Figura 8: área de armadilhamento no Parque Estadual Alberto Löfgren (Horto Florestal), São Paulo, SP

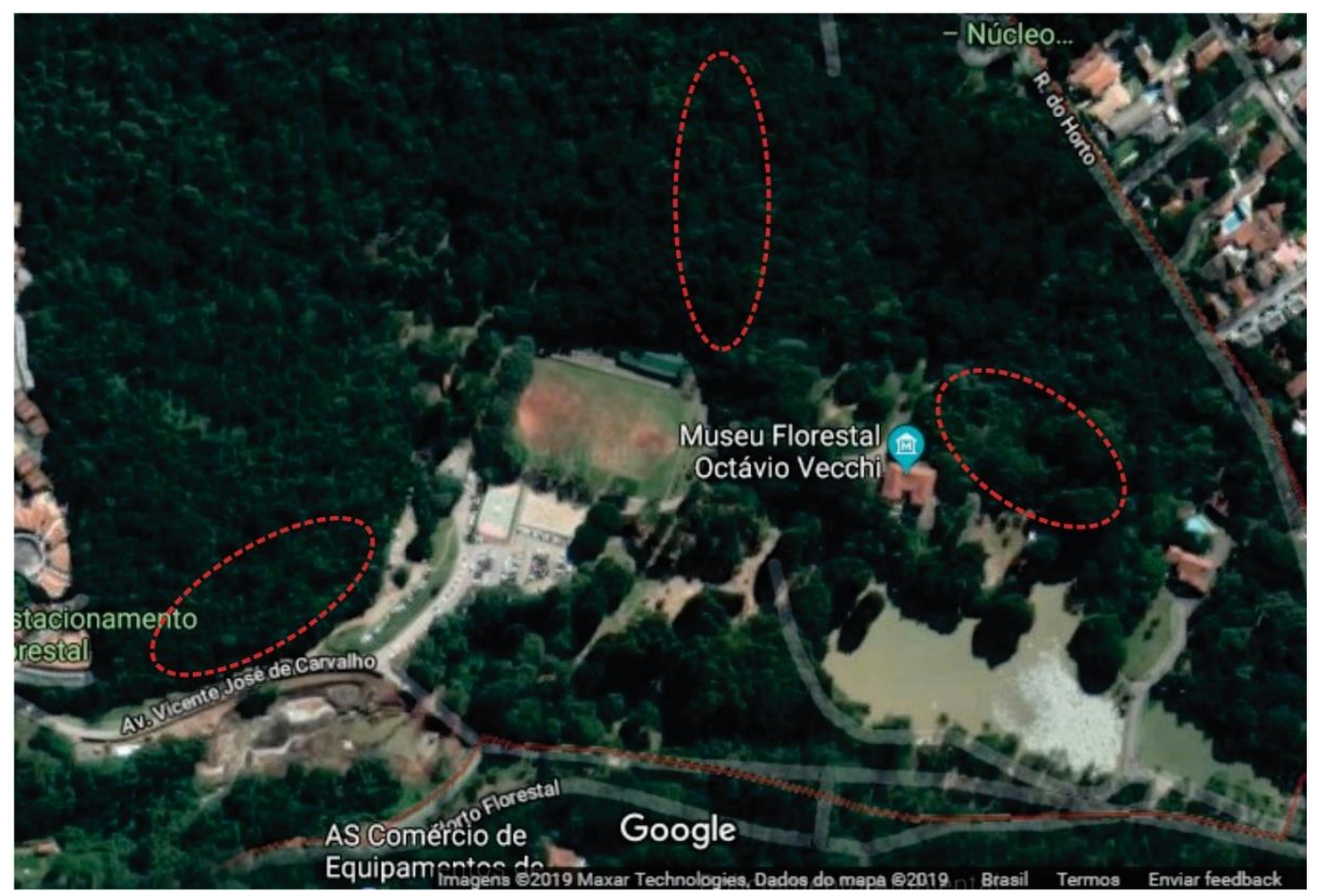

Google, 2019

O Pantanal de Poconé, situado na cidade de Poconé, estado do Mato Grosso, é caracterizado por vegetação típica de cerrado, predominantemente, além de áreas compostas de florestas, campos de pastagem e ambientes aquáticos (FERNANDES, 2010). A Base Avançada de Pesquisa do Pantanal, mantida pela Universidade Federal do Mato Grosso, foi o local selecionado para realização das coletas; o local possui um hectare compreendendo área construída e paisagem típica do Pantanal (UFMT, 2016). o munícipio de Poconé não tem registro de casos de FMB (BRASIL, 2019). A figura 9 mostra a área onde foram colocadas as linhas de armadilha nesse local. 
Figura 9: área de armadilhamento na Base Avançada de Pesquisa do Pantanal, Poconé, MT

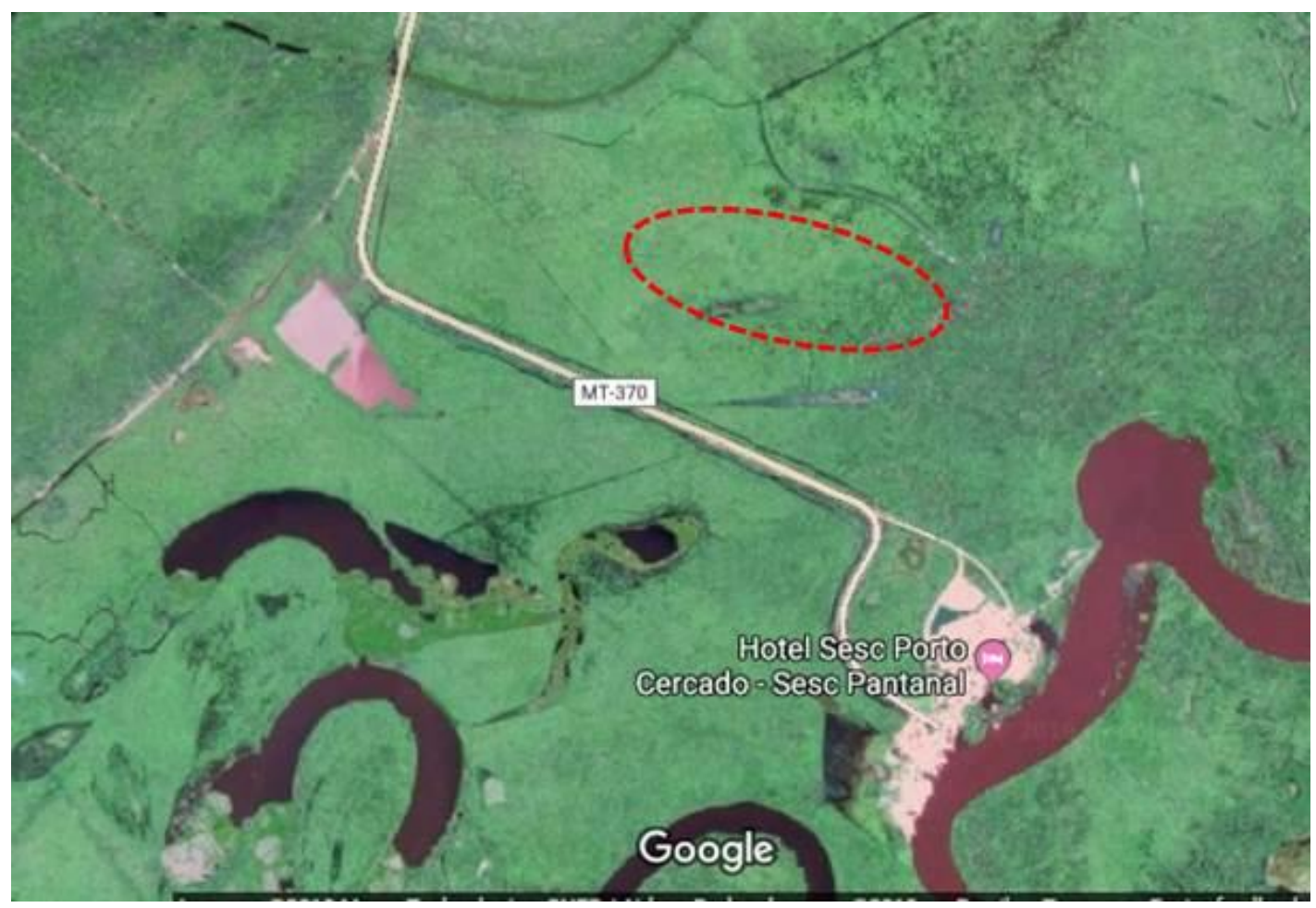

Google, 2019

O Pantanal da Nhecolândia tem a grande maioria da sua área inserida na cidade de Corumbá, estado do Mato Grosso do Sul; a base de trabalho do projeto foi fixada na estação experimental da Embrapa Pantanal, na Fazenda Nhumirim, e as coletas foram realizadas nas fazendas São José e Retiro Manduvi, com vegetação caraterística de cerrado e cerradão sem alagamento periódico, campos inundáveis e ambientes aquáticos, como lagoas de água doce ou salobra, rios, vazantes e canais para escoamento da água; além das áreas construídas das sedes das fazendas (EMBRAPA PANTANAL, [s.d.]). A cidade de Corumbá não tem casos de FMB registrados (BRASIL, 2019). A figura 10 mostra a área onde foram colocadas as linhas de armadilha nesse local. 
Figura 10: área de armadilhamento Pantanal da Nhecolândia, Corumbá, MS

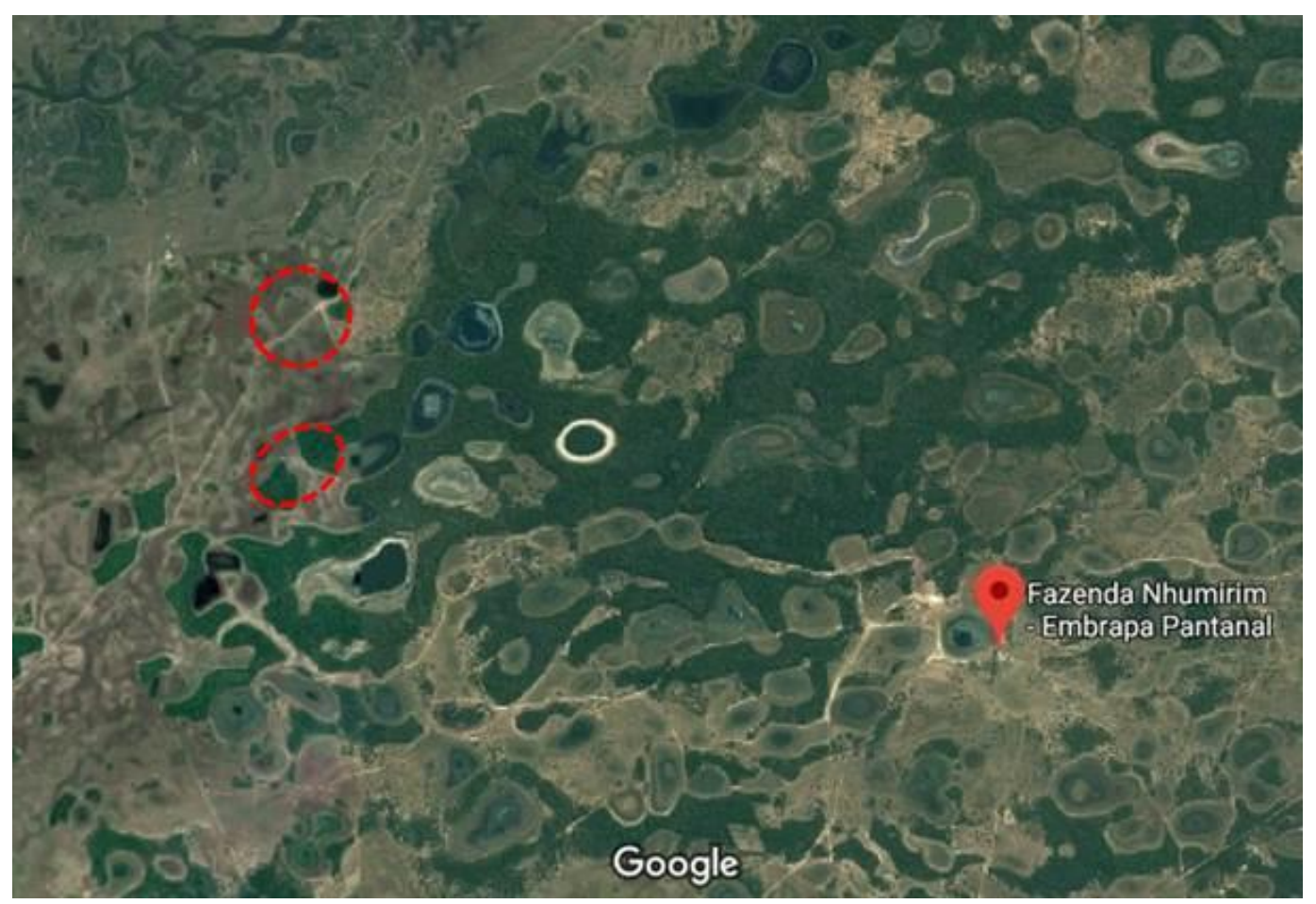

Google, 2019

\subsection{Captura de Pequenos Mamíferos}

A captura dos pequenos mamíferos ocorreu em duas campanhas por ano, sendo uma realizada na estação seca e outra na estação chuvosa para mensurar possíveis diferenças entre as duas estações. Essas campanhas se iniciaram na estação seca de 2015 e terminaram na estação seca de 2018, totalizando três anos consecutivos de coleta de dados.

O esforço de captura médio empregado nas áreas variou de acordo com o número de "linhas de armadilhas" montadas em cada localidade. Cada "linha de armadilha" foi composta por cinco pontos de captura com distância de 10 metros entre os pontos, totalizando uma linha de 50 metros. Em cada ponto de captura foram colocadas três armadilhas, sendo uma tipo Tomahawk no solo, uma tipo Shermann no solo e uma tipo Shermann no alto, geralmente colocada em árvores ou cipós, somando 15 armadilhas por linha.

As áreas E1, NE1 e NE2 tiveram em média 13 linhas totalizando 780 armadilhas-noite por campanha uma vez que o espaço disponível selecionado para colocação das linhas era semelhante. Seguindo esse critério, E2 e E3, por serem menores, tiveram em média 600 e 660 armadilhas-noite por campanha, dispostas em 10 e 11, linhas em média respectivamente. 
BIO1 manteve o número de 15 linhas durante as campanhas, totalizando 900 armadilhas-noite de esforço de captura, enquanto BIO2 teve média de 12 linhas montadas, com esforço médio de 720 armadilhas-noite. Durante a campanha das chuvas/2017-2018 na área NE2 e da seca/2018 na BIO2, apenas seis linhas foram colocadas devido a problemas logísticos que resultaram em incapacidade de acessar essas áreas na sua totalidade.

As armadilhas ficaram abertas durante quatro noites consecutivas em cada área, e todas foram iscadas com uma rodela de banana e uma mistura de paçoca, aveia e sardinha; essa isca era substituída após 48 horas ou sempre que necessário. A cada manhã as armadilhas eram vistoriadas em busca de animais capturados. O quadro 2 indica o esforço de captura em cada área a cada campanha e no total.

Quadro 2. Número de linhas de armadilhas para captura de pequenos mamíferos, montadas em cada área a cada campanha, entre os anos de 2015 e 2018.

\begin{tabular}{|c|c|c|c|c|c|c|c|c|}
\hline \multicolumn{8}{|c|}{ Campanha de Captura } & \multirow{2}{*}{$\begin{array}{l}\text { Esforço total de captura } \\
\text { (armadilhas.noite) }\end{array}$} \\
\hline Área & $\begin{array}{l}\text { Seca } \\
2015\end{array}$ & $\begin{array}{c}\text { Chuva } \\
2015- \\
2016\end{array}$ & $\begin{array}{l}\text { Seca } \\
2016\end{array}$ & $\begin{array}{c}\text { Chuva } \\
2016- \\
2017\end{array}$ & $\begin{array}{l}\text { Seca } \\
2017\end{array}$ & $\begin{array}{c}\text { Chuva } \\
2017- \\
2018 \\
\end{array}$ & $\begin{array}{l}\text { Seca } \\
2018\end{array}$ & \\
\hline E1 & 5 & 13 & 13 & 13 & 11 & 13 & 13 & 848 \\
\hline $\mathrm{E} 2$ & 10 & - & 10 & 10 & 9 & 10 & 10 & 3540 \\
\hline E3 & 10 & - & 10 & 10 & 11 & 11 & 11 & 4860 \\
\hline NE1 & 13 & 13 & 13 & 13 & 13 & 13 & 13 & 5642 \\
\hline NE2 & 10 & 13 & 13 & 13 & 13 & 6 & 13 & 4860 \\
\hline NE3 & 9 & - & - & - & - & - & - & 540 \\
\hline BIO1 & 15 & - & 15 & 15 & 15 & 15 & 15 & 5400 \\
\hline $\mathrm{BIO} 2$ & 18 & 12 & - & 12 & 12 & - & 6 & 3600 \\
\hline
\end{tabular}

E1: campus "Luiz de Queiroz" (ESALQ) em Piracicaba-SP; E2: Estação de Tratamento de Esgoto Carioba em Americana-SP; E3: campus da UFSCar em Araras-SP; NE1: Campus da USP em Pirassununga-SP; NE2: Campus da USP em Ribeirão Preto-SP; NE3: Parque Estadual Alberto Löfgren em São Paulo-SP; BIO1: Pantanal de Poconé, em Poconé-MS; BIO2: Pantanal da Nhecolândia, em Corumbá-MS. *média de armadilhas.noite

Os animais capturados nas armadilhas foram sedados com aproximadamente $100 \mathrm{mg} / \mathrm{kg}$ de cloridrato de quetamina mais $10 \mathrm{mg} / \mathrm{kg}$ de cloridrato de xilazina por via intramuscular para realização da triagem. Sob efeito de sedação, os pequenos mamíferos foram identificados morfologicamente, até nível de gênero pelo menos, e suas medidas e peso foram aferidos para biometria. A identificação foi realizada com o auxílio de chaves contidas nos guias de mamíferos de Reis et al. (2006) para roedores e marsupiais, e Bonvicino (2008) para roedores. 
Com os animais ainda sedados foi coletado sangue venoso por punção da veia lateral caudal ou punção intracardíaca, com seringa (com capacidade para um ou três mililitros dependendo do tamanho do animal) e agulha, e o sangue coletado foi acomodado em microtubos identificados de acordo com cada área seguindo uma numeração pré-estabelecida. Em seguida foi realizada a coleta de carrapatos (larvas, ninfas ou adultos) através de minuciosa vistoria em todo o corpo do animal com o auxílio de uma pinça fina, e os espécimes encontrados parasitando os pequenos mamíferos foram acondicionados em microtubos contendo álcool absoluto, também identificados de acordo com os códigos para cada área.

Alguns indivíduos de cada espécie amostrada de cada uma das áreas foram submetidos ao procedimento de eutanásia, fixados e enviados a Coleção Zoológica do Laboratório de Zoologia dos Vertebrados da ESALQ-USP, em Piracicaba, para tombamento e confirmação da identificação taxonômica, servindo assim de espécime testemunho. Nesses casos em que foi realizada a eutanásia, amostras de órgãos internos (baço, fígado e pulmão) foram colhidas, acondicionadas em microtubos e em seguida congeladas a $-20^{\circ} \mathrm{C}$. Por fim, após a realização da triagem os animais não-coletados foram marcados com brincos numerados e, após retorno da anestesia, soltos no mesmo local da captura.

As comunidades de pequenos mamíferos de cada tipo de área foram avaliadas quanto à riqueza (número de espécies existentes em determinada área) e equabilidade (similaridade de representação das espécies em uma comunidade), representadas através do Diagrama de Whittaker. Esse diagrama é um índice de diversidade utilizado para expressar esses dois componentes da diversidade, considerados importantes para descrever as características das comunidades de pequenos mamíferos amostradas em cada tipo de área (MELO, 2008). Alem disso, as taxas de captura de animais foram comparadas entre estação seca e chuvosa por um teste de qui-quadrado.

\subsection{Identificação dos carrapatos}

Os carrapatos coletados parasitando os pequenos mamíferos capturados em campo foram transportados ao laboratório de Doenças Parasitárias do departamento de Medicina Veterinária Preventiva da FMVZ-USP em São Paulo - SP. A identificação das espécies dos carrapatos foi realizada morfologicamente nos estágios adultos segundo as chaves de Aragão e Fonseca (1961) e Barros-Battesti et al. (2006), e no estágio de ninfa segundo a chave de 
Martins et al. (2010). As larvas foram classificadas morfologicamente até o gênero, segundo a chave de Barros-Battesti et al. (2006), e eventualmente até o nível de espécie por análises moleculares, através de determinação da sequência de DNA de um fragmento do gene mitocondrial 16S rDNA de carrapatos, segundo Mangold et al. (1998). A ocorrência de carrapatos sobre os pequenos mamíferos foi descrita a partir da prevalência (definição) total e de cada espécie de hospedeiro por tipo de área.

\subsection{Sorologia para detecção de anticorpos anti-Rickettsia}

O sangue coletado de todos os animais capturados teve o soro separado por centrifugação na velocidade de $16000 \mathrm{~g}$ por 10 minutos, ainda em campo ao final de cada dia de coleta, e em seguida foi congelado a $-20^{\circ} \mathrm{C}$ para ser transportado para o Laboratório de Doenças Parasitárias da FMVZ-USP, onde a reatividade desses soros frente aos antígenos de Rickettsia foi testada pela Reação de Imunofluerescência Indireta (RIFI) segundo protocolo descrito por Horta et al. (2004).

Para a RIFI foram utilizadas lâminas de cinco cepas isoladas no Brasil, Rickettsia rickettsii cepa Taiaçu (PINTER; LABRUNA,2006), Rickettsia parkeri cepa At24 (SILVEIRA et al., 2007), Rickettsia amblyommatis Ac37 (LABRUNA et al., 2004a), Rickettsia rhipicephali HJ5 (LABRUNA et al.,2005) e Rickettsia bellii cepa Mogi (PINTER; LABRUNA, 2006). O antígeno para produção das lâminas foi obtido a partir de cultivo celular no próprio laboratório conforme protocolo descrito por Horta et al. (2004).

As reações foram conduzidas por grupos de hospedeiros relacionados filogeneticamente (Cricetidae + Muridae; Didelphidae; e Echymyidae + Caviidae), em função do conjugado disponível. Para cricetídeos e murídeos foi utilizado conjugado anti-mouse IgG (Sigma, St Louis, MO, USA) diluído em solução salina tamponada com fosfato (PBS) pH 7,4 na proporção 1:500. Para equimídeos e cavídeos foi utilizado conjugado anti-guinea pig IgG (Sigma, St Louis, MO, USA) diluído em PBS 1:400, e para didelfídeos (marsupiais), o conjugado anti-gambá IgG (CCZ, São Paulo, Brasil) diluído em PBS 1:400. Todas as amostras sorológicas foram diluídas em PBS na proporção de 1:64. Amostras reativas nessa diluição foram diluídas em dobras consecutivas $(1: 64,1: 128,1: 256,1: 512,1: 1024$ e assim sucessivamente) até a última diluição reativa. Foram considerados reagentes aqueles soros com títulos $\geq 1: 64$. A reação sorológica foi considerada homóloga a um antígeno específico quando o título final para uma espécie de riquétsia foi $\geq 4 \mathrm{x}$ aqueles observados para outras 
espécies de riquétsias. Somente nesse caso foi determinado o provável antígeno causador da reação. Em todas as lâminas, junto às amostras, foram testados soros controles positivos e negativos na diluição de 1:64 (HORTA et al., 2004).

\subsection{Análises Moleculares}

Os carrapatos coletados e mantidos no álcool absoluto foram submetidos à extração de DNA pela técnica de Isotiocianato de Guanidina, (SANGIONI et al. 2005), no Laboratório de Doenças Parasitárias da FMVZ-USP. As amostras foram constituídas por carrapatos individuais, no caso de exemplares únicos de um hospedeiro ou carrapatos em estágio adulto, e em pools de carrapatos de uma mesma espécie e estágio de desenvolvimento (larvas e ninfas), cujo número de espécimes foi variável de acordo com a infestação por hospedeiro individual.

Os fragmentos de fígado, baço e pulmão coletados dos pequenos mamíferos (roedores e marsupiais) eutanasiados foram submetidos à extração de DNA por meio de kit comercial (DNeasy® Tissue kit, Qiagen) conforme instruções do fabricante. Coágulos sanguíneos de gambás (Didelphis sp.) mantidos congelados a $-20^{\circ} \mathrm{C}$ após a separação do soro por centrifugação também foram processados pelo mesmo protocolo de extração.

Todas as amostras de DNA extraído foram inicialmente submetidas a uma triagem por PCR em tempo real (7500 Real Time PCR Systems apparatus - Applied Bio Systems, Foster City, CA, USA) para pesquisa de bactérias do gênero Rickettsia usando os primers CS-5 e CS-6, que amplificam o fragmento de 147-bp do gene da proteína citrato sintase (gltA) existente em todas as espécies de riquétsias, incluindo uma sonda interna ([5, 6-FAM d(CATTGTGCCATCCAGCCTACGGT) BHQ-1 3'] como previamente descrito por Labruna et al. (2004b) e Guedes et al. (2005). As amostras negativas nesta etapa foram processadas por PCR convencional para validação da extração e confirmação do resultado negativo na PCR real time. Para carrapatos o protocolo foi à amplificação de um fragmento de 460-bp do gene mitocondrial 16S rRNA de carrapatos (MANGOLD et al. 1998) e para as amostras de tecido e sangue dos pequenos mamíferos à amplificação de um fragmento de 359-bp do gene citocromo B (cyt-B) da mitocôndria de vertebrados (STEUBER et al., 2005).

As amostras positivas na PCR em tempo real foram processadas por PCR convencional conforme descrito por Labruna et al. (2004b). Foram usados os iniciadores CS78 e CS-323 que amplificam o fragmento de 401-bp do gene da proteína citrato sintase ( $g l t A)$, 
existente em todas as espécies de riquétsias. Para amostras com resultados positivo nessa etapa foi feita outra PCR a fim de amplificar o fragmento de 632-bp do gene da 190-kDa da proteína externa de membrana (ompA) presente somente nas riquétsias do GFM usando primers Rr190.70F e Rr190.701R (Roux et al. 1996). Por fim, as amostras negativas no ompA foram submetidas à PCR específica para Rickettsia bellii (Szabó et al., 2013b), bactéria que não se encaixa no grupo das riquétsias causadoras da FMB, mas comumente encontrada infectando carrapatos. Os primers utilizados na execução dos protocolos estão descritos no quadro 3 e um resumo dos mesmos está descrito nas figuras $11 \mathrm{~A}$ e $11 \mathrm{~B}$

Quadro 3: Lista dos primers utilizados nas reações de PCR para pesquisa de bactérias do gênero Rickettsia em carrapatos e tecidos de pequenos mamíferos capturados em áreas endêmicas e não endêmicas para febre maculosa, entre 2015 e 2018.

\begin{tabular}{|c|c|c|c|c|}
\hline $\begin{array}{l}\text { Gene alvo e pares de } \\
\text { primers }\end{array}$ & Especificidade & Sequência dos primers $\left(5^{\prime} \rightarrow 3^{\prime}\right)$ & $\begin{array}{c}\text { Fragmento } \\
\text { amplificado }(b p)^{*}\end{array}$ & Referência \\
\hline $\begin{array}{l}\text { gltA } \\
\text { CS-5 } \\
\text { CS-6 }\end{array}$ & $\begin{array}{l}\text { Gênero } \\
\text { Rickettsia }\end{array}$ & $\begin{array}{l}\text { GAGAGAAAATTATATCCAAATGTTGAT } \\
\text { AGGGTCTTCGTGCATTTCTT }\end{array}$ & 147 & $\begin{array}{c}\text { Labruna et al. } \\
\text { (2004b) e Guedes } \\
\text { al. (2005) }\end{array}$ \\
\hline $\begin{array}{l}16 \mathrm{~S} \text { rRNA } \\
\text { mitocondrial } \\
16 \mathrm{~S}^{+1} \\
16 \mathrm{~S}^{-1}\end{array}$ & $\begin{array}{l}\text { 16S miticondrial de } \\
\text { carrapatos }\end{array}$ & $\begin{array}{l}\text { CCGGTCTGAACTCAGATCAAGT } \\
\text { GCTCAATGATTTTTTAAATTGCTGT }\end{array}$ & 460 & $\begin{array}{l}\text { Mangold et al. } \\
\text { (1998) }\end{array}$ \\
\hline $\begin{array}{l}\text { Citocromo B } \\
\text { mitocondrial } \\
\text { CYT B1 } \\
\text { CYT B2 }\end{array}$ & $\begin{array}{l}\text { Citocromo B da } \\
\text { mitocôndria de } \\
\text { mamíferos }\end{array}$ & $\begin{array}{l}\text { CCATCCAACATCTCAGCATGATGAAA } \\
\text { GCCCCTCAGAATGATATTTGTCCTCA }\end{array}$ & 359 & $\begin{array}{l}\text { Steuber } \\
\text { et al. }(2005)\end{array}$ \\
\hline $\begin{array}{c}\text { gltA } \\
\text { CS-78 } \\
\text { CS- } 323\end{array}$ & Gênero Rickettsia & $\begin{array}{c}\text { GCAAGTATCGGTGAGGATGTAAT } \\
\text { GCTTCCTTAAAATTCAATAAATCAGGAT }\end{array}$ & 401 & $\begin{array}{l}\text { Labruna et al. } \\
\qquad(2004 b)\end{array}$ \\
\hline $\begin{array}{c}\text { ompA } \\
\operatorname{Rr} 190.70 \\
\operatorname{Rr} 190.701 \\
\end{array}$ & $\begin{array}{c}\text { Grupo da } \\
\text { Febre Maculosa }\end{array}$ & $\begin{array}{l}\text { ATGGCGAATATTTCTCCAAAA } \\
\text { GTTCCGTTAATGGCAGCATCT }\end{array}$ & 632 & $\begin{array}{l}\text { Roux } \\
\text { et al. (1996) }\end{array}$ \\
\hline $\begin{array}{c}\text { gltA } \\
\text { R. bellii }\end{array}$ & R. bellii & $\begin{array}{l}\text { ATCCTGATTTGCTGAATTTTTT } \\
\text { TGCAATACCAGTACTGACG }\end{array}$ & 338 & $\begin{array}{l}\text { Szabo } \\
\text { et al. }(2013)\end{array}$ \\
\hline
\end{tabular}

*(bp): pares de base 
Figura 11: Etapas de execução do protocolo de PCR para pesquisa de bactérias do gênero Rickettsia em carrapatos e tecidos de pequenos mamíferos capturados em áreas endêmicas e não endêmicas para febre maculosa, entre 2015 e 2018.
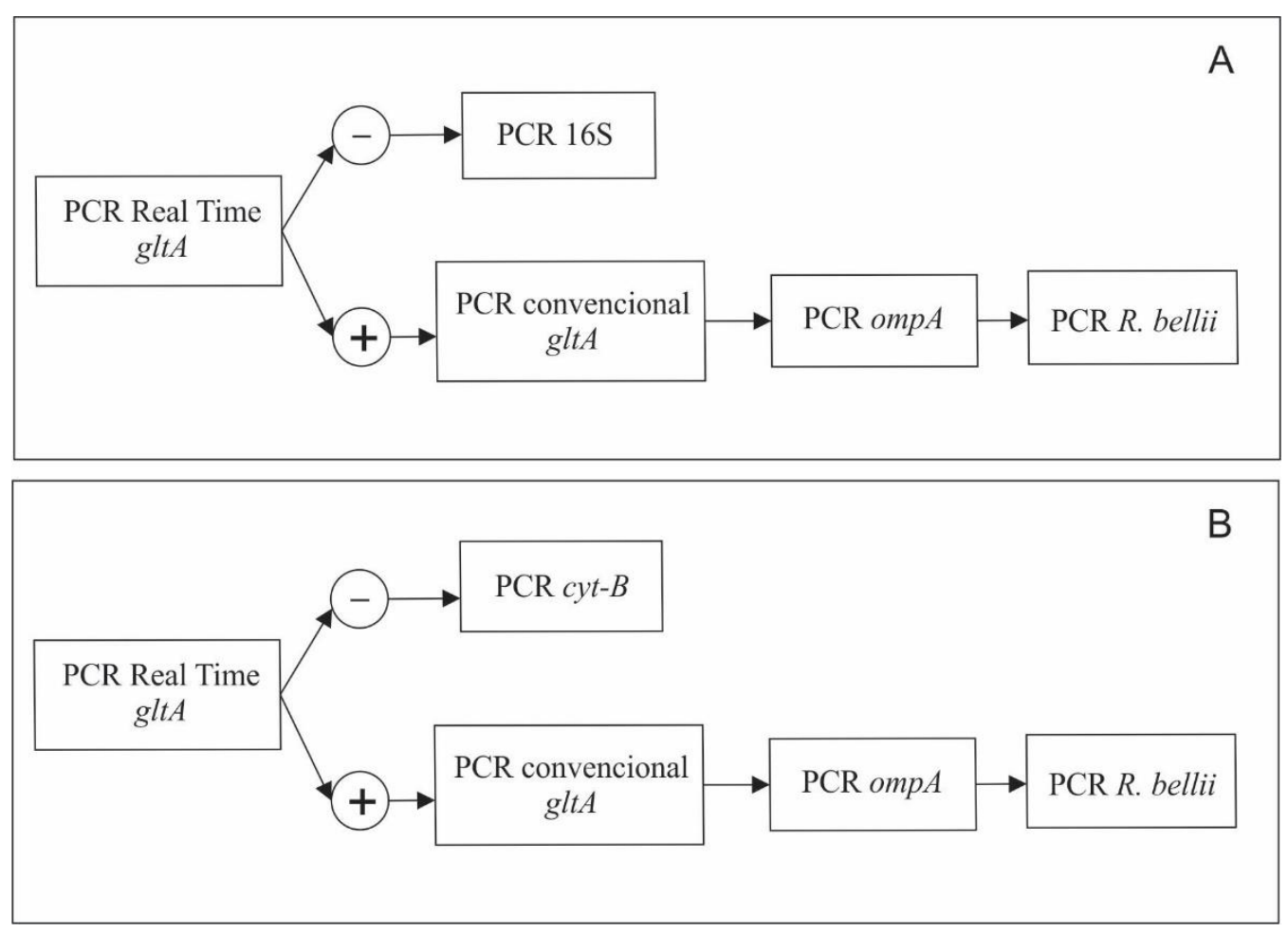

A: etapas do protocolo para pesquisa de bactérias do gênero Rickettsia em carrapatos. B: etapas do protocolo para pesquisa de bactérias do gênero Rickettsia em tecidos (fígado, pulmão e baço) de roedores e marsupiais, e coágulos sanguíneos de Didelphis sp.

Os produtos amplificados da reação de PCR foram submetidos à eletroforese em gel de agarose a $1,5 \%\left(100 \mathrm{ml}\right.$ TBE $0,5 \% ; 2,0 \mathrm{~g}$ agarose UltraPure ${ }^{\mathrm{TM}}$ Agarose Invitrogen $\left.^{\mathrm{TM}}\right)$ corado com Sybr Safe ${ }^{\circledR}$ Invitrogen $^{\mathrm{TM}}$ em cuba horizontal com solução tampão TBE 0,5X $(0,045$ M Tris-borato; 0,001 M EDTA pH 8,0) submetida à voltagem de 1 a $10 \mathrm{~V} / \mathrm{cm}$ durante 45 minutos. A visualização das bandas foi feita em transiluminador ultravioleta (AlphaImager®).

\subsection{Sequenciamento de DNA dos Produtos de PCR}

Todos os produtos de PCR positivos gerados nas amostras de campo testadas pelos protocolos de PCR descritos acima foram purificados utilizando o produto comercial ExoSAP-IT (USB Corporation) e sequenciados utilizando-se o kit comercial BigDye ${ }^{\mathrm{TM}}$ Terminator - Cycle Sequencing Ready Reaction - Applied Biosystems. Foi utilizado o sequenciador de DNA modelo ABI 3500 Genetic Analyser (Applied Biosystens/Perkin 
Elmer), segundo seu manual de instruções. As sequências obtidas foram editadas pelo pacote de programas SeqMan® (Lasergene, DNAstar, Madison, Wis.) e submetidas à análise de similaridade com as seqüências disponíveis no GenBank, através do programa Basic Local Alignment Search Tool (BLAST two sequences analysis) (Altschul et al., 1990).

\subsection{Estrutura de Habitat}

Uma avaliação da estrutura do habitat foi incorporada ao plano de trabalho, a partir de 2016, com o objetivo de avaliar a estrutura do hábitat das áreas de uso dos grupos de capivaras, principalmente no que se refere a características da vegetação. Foram elencados alguns parâmetros de avaliação que pudessem interferir principalmente na presença de carrapatos e pequenos mamíferos. Para tal, foi estabelecida como unidade amostral a mesma linha utilizada para captura de pequenos mamíferos (50m de comprimento por $2 \mathrm{~m}$ de largura) e as variáveis foram aferidas uma vez ao ano durante as coletas realizadas nas secas. Devido à impossibilidade de se coletar dados de todas as linhas, padronizou-se a amostragem de três linhas sorteadas ao acaso em cada local de uso pelas capivaras. As variáveis e seus parâmetros medidos, adaptados de Voltolini et al. (2009), Chapman et al (1992) foram:

a) Dossel: a caracterização dos componentes arbóreos mais altos, que formam o dossel das áreas de mata, foi feita em relação à altura da copa, quantidade de luz que a atravessa, e desenvolvimento dos indivíduos que o compõem. Foram avaliados o diâmetro à altura do peito (DAP $>15 \mathrm{~cm}$ ), fazendo-se a medida da circunferência das árvores com fita métrica comum, a 1,30m em relação ao solo, e anotação dos valores maiores que $15 \mathrm{~cm}$, para cálculo posterior do diâmetro. Todos os indivíduos presentes na linha foram amostrados. Para todas as árvores com DAP $>15 \mathrm{~cm}$, foi medida também sua altura com o auxílio de um clinômetro digital posicionado a $15 \mathrm{~m}$ da árvore. A abertura do dossel foi estimada com auxílio de um quadrante de 50 x 50cm, transparente e quadriculado em 100 subunidades, posicionado na horizontal, acima dos olhos do pesquisador, no centro da parcela. Foram quantificadas as subunidades do quadrante que apresentaram preenchimento, pela imagem do dossel, maior ou igual a 50\% de sua área.

b) Sub-bosque: a complexidade do estrato mediano da mata foi aferida utilizando-se uma haste com subdivisões a cada $20 \mathrm{~cm}$ (vara telescópica de $2 \mathrm{~m}$ ), posicionada na vertical no centro da parcela. A uma distância de $2 \mathrm{~m}$, foram quantificadas as partes vegetais posicionadas 
em cada classe de altura 9 da haste. Ainda, foram contados todos os indivíduos, ao longo da linha, cuja circunferência foi menor que $15 \mathrm{~cm}$ e altura maior que $50 \mathrm{~cm}$.

c) Regenerantes: o nível de recomposição da mata foi mensurada pela contagem e registro da altura de todos os indivíduos abaixo de $50 \mathrm{~cm}$ ao longo da linha.

d) Frutificação: para avaliar parte dos recursos alimentares oferecidos pela mata aos pequenos mamíferos, os indivíduos frutificados (incluindo nos estratos baixos), foram quantificados e, conforme possibilidade, foram também identificados. Para isso, coletou-se um fruto e um ramo com folhas (quando isso não foi possível, tais partes foram fotografadas).

e) Serrapilheira: o acúmulo de folhiço sobre o solo forma um estrato que oferece microambiente importante para fases não parasitárias dos carrapatos. Assim, a temperatura e a umidade da serrapilheira foram registradas por meio de um datalogger colocado no meio da linha no primeiro dia de coleta, e programado para registros a cada 1h. Após quatro dias, foi retirado e seus dados passados ao computador. A profundidade do estrato foi medida inserindo-se uma régua no centro da parcela. Após medir a profundidade, toda a serrapilheira da parcela foi transferida a um saco e pesada em balança de precisão em campo.

Cada variável medida foi comparada entre as E e as NE por meio de um teste de Mann-Whitney, assumindo nível de significância igual a 5\% (ZAR, 1999). Os dados de temperatura e umidade registrados pelo data logger foram utilizados para o calculo do déficit hídrico, dados pela formula DH $=(1$-UR 100 $) \times 4.9463 \times \mathrm{e}\left(0.0621^{*} \mathrm{~T}\right)$; onde DH e expresso em milímetros de mercúrio, UR em porcentagem e $\mathrm{T}$ em graus Celsius (PERRET et al., 2000). Ainda, foi testada uma correlação de Spearman entre o DH e o numero de carrapatos encontrados sobre pequenos mamíferos na área correspondente (ZAR 1999), considerando nível de significância de 0,05 . 


\section{Resultados}

\subsection{Diversidade de Pequenos Mamíferos}

Entre as estações secas de 2015 e de 2018 foram realizadas sete campanhas de captura de pequenos mamíferos nas áreas selecionadas para o projeto, sendo quatro na estação seca e três na estação chuvosa. Em algumas áreas não foi possível cumprir todas essas campanhas por questões logísticas. Assim, as áreas E2, E3 e BIO1 não foram amostradas na estação chuvosa de 2015-2016; enquanto a área BIO2 não foi amostrada na estação seca de 2016 e teve amostragem parcial nas chuvas de 2015-2016. A área NE2 também teve amostragem parcial nas chuvas de 2017-2018, e a área NE3 foi retirada do projeto em 2016 devido à redução quase total da população de capivaras do local.

No total foram capturados 629 animais de 27 espécies diferentes, principalmente pequenos roedores e marsupiais, tendo sido registrados também alguns indivíduos de outras ordens. Nas áreas E foram catalogadas 13 espécies diferentes (sete na estação chuvosa e 11 na estação seca), nas áreas NE 16 (sete nas chuvas e 16 na seca) e nas BIO 14 (seis nas chuvas e 13 na seca). A estação seca mostrou maior taxa de captura absoluta de indivíduos e de número de espécies em relação a estação chuvosa em todas as áreas. A estação seca mostrou maior taxa de captura absoluta de número de espécies e de indivíduos $\left(\mathrm{U}_{\mathrm{E}}=0,5\right.$ e $\mathrm{p}=0,05$; $\mathrm{U}_{\mathrm{NE}}$, BIO $=0,000 \mathrm{p}=0,034)$ em relação a estação chuvosa em todas as áreas.

Nas áreas E e NE a espécie mais abundante foi o gambá de orelha branca, Didelphis albiventris, com 66 e 65 indivíduos capturados respectivamente; enquanto nas BIO, houve maior número de capturas $(\mathrm{n}=67)$ de roedores do gênero Oecomys. As áreas com maior grau de antropização (E e NE) apresentaram oito espécies de hospedeiros em comum entre si (Cavia sp., Necromys lasiurus, Oligoryzomys nigripes, Rattus rattus, Euryoryzomys russatus, Didelphis albiventris, Didelphis aurita e Gracilinanus agilis), e três com as áreas menos antropizadas (Necromys lasiurus, Gracilinanus agilis e Didelphis albiventris). Nas E, Dasypus novencinctus, Galictis cuja e Mus musculus foram exclusivas dessas áreas. Akodon sp., Juliomys cf assitenuis, Nectomys squamipes, Philander sp. e Micoureus constantinae foram exclusivas das NE e Clyomys laticeps, Dasyprocta azarae, Monodelphis domestica e Thrichomys pachyurus, exclusivas das BIO. A tabela 1 apresenta o número de animais capturados por área e por espécie em cada uma das campanhas realizadas. 
Tabela 1. Número de pequenos mamíferos capturados nos três tipos de área (endêmicas e não endêmicas com alto grau de antropização e não endêmicas com baixo grau de antropização) em cada campanha de captura durante o período de 2015 a 2018

\begin{tabular}{|c|c|c|c|c|c|c|c|}
\hline \multirow[b]{2}{*}{ Espécies capturadas } & \multicolumn{6}{|c|}{ Campanha de Captura } & \multirow[b]{2}{*}{$\begin{array}{l}\text { Seca } \\
2018 \\
\end{array}$} \\
\hline & $\begin{array}{l}\text { Seca } \\
2015\end{array}$ & $\begin{array}{c}\text { Chuva } \\
2015-2016\end{array}$ & $\begin{array}{l}\text { Seca } \\
2016\end{array}$ & $\begin{array}{c}\text { Chuva } \\
\text { 2016-2017 }\end{array}$ & $\begin{array}{l}\text { Seca } \\
2017\end{array}$ & $\begin{array}{c}\text { Chuva } \\
\text { 2017-2018 }\end{array}$ & \\
\hline \multicolumn{8}{|c|}{ ÁREAS ENDÊMICAS COM ALTO GRAU DE ANTROPIZAÇÃO } \\
\hline Cavia sp. & 0 & 0 & 1 & 0 & 1 & 0 & 0 \\
\hline Dasypus novencinctus & 0 & 1 & 0 & 0 & 0 & 0 & 0 \\
\hline Didelphis albiventris & 13 & 2 & 16 & 9 & 11 & 1 & 14 \\
\hline Didelphis aurita & 0 & 0 & 1 & 0 & 0 & 0 & 0 \\
\hline Euryoryzomys russatus & 0 & 0 & 0 & 4 & 0 & 0 & 0 \\
\hline Galictis cuja & 0 & 0 & 1 & 0 & 0 & 0 & 0 \\
\hline Gracilinanus agillis & 0 & 0 & 0 & 0 & 5 & 2 & 0 \\
\hline Gracilinanus microtarsus & 1 & 0 & 1 & 0 & 0 & 0 & 5 \\
\hline Necromys lasiurus & 1 & 0 & 3 & 3 & 2 & 2 & 1 \\
\hline Nasua nasua & 0 & 0 & 0 & 0 & 0 & 0 & 1 \\
\hline Mus musculus & 1 & 0 & 0 & 0 & 0 & 0 & 0 \\
\hline Oligoryzomys nigripes & 3 & 1 & 7 & 4 & 2 & 0 & 10 \\
\hline Rattus rattus & 8 & 0 & 0 & 3 & 1 & 1 & 4 \\
\hline N.I. & 0 & 0 & 0 & 0 & 1 & 0 & 0 \\
\hline \multicolumn{8}{|c|}{ ÁREAS NÃO ENDÊMICAS COM ALTO GRAU DE ANTROPIZAÇÃO } \\
\hline Akodon sp. & 6 & 2 & 5 & 0 & 0 & 0 & 2 \\
\hline Cavia sp. & 0 & 0 & 0 & 0 & 1 & 0 & 0 \\
\hline Didelphis albiventris & 7 & 6 & 12 & 16 & 6 & 6 & 12 \\
\hline Didelphis aurita & 10 & 0 & 0 & 0 & 0 & 0 & 0 \\
\hline Euryoryzomys russatus & 9 & 0 & 0 & 0 & 0 & 0 & 0 \\
\hline Gracilinanus agillis & 2 & 1 & 7 & 2 & 21 & 0 & 17 \\
\hline Hylaeamys megacephalus & 0 & 0 & 2 & 1 & 4 & 0 & 0 \\
\hline Juliomys cf assitenuis & 1 & 0 & 1 & 0 & 0 & 0 & 0 \\
\hline Micoureus constantinae & 2 & 0 & 2 & 0 & 0 & 0 & 0 \\
\hline Necromys lasiurus & 0 & 0 & 0 & 0 & 1 & 0 & 0 \\
\hline Nectomys squamipes & 1 & 4 & 5 & 1 & 11 & 0 & 1 \\
\hline Oligoryzomys nigripes & 5 & 7 & 15 & 5 & 11 & 2 & 5 \\
\hline Oecomys sp. & 0 & 0 & 0 & 0 & 1 & 0 & 0 \\
\hline Cerradomys sp. & 0 & 0 & 0 & 0 & 1 & 0 & 0 \\
\hline Philander sp. & 0 & 0 & 0 & 0 & 0 & 0 & 1 \\
\hline Rattus rattus & 1 & 0 & 1 & 2 & 4 & 1 & 2 \\
\hline N.I. & 0 & 0 & 0 & 0 & 2 & 0 & 1 \\
\hline \multicolumn{8}{|c|}{ ÁREAS NÃO ENDÊMICAS COM BAIXO GRAU DE ANTROPIZAÇÃO } \\
\hline Cerradomys subflavus & 0 & 0 & 0 & 0 & 0 & 0 & 1 \\
\hline Clyomys laticeps & 2 & 0 & 0 & 0 & 0 & 0 & 0 \\
\hline Dasyprocta azarae & 2 & 0 & 2 & 0 & 0 & 0 & 0 \\
\hline Didelphis albiventris & 0 & 1 & 0 & 0 & 0 & 0 & 0 \\
\hline Gracilinanus agillis & 12 & 0 & 4 & 0 & 0 & 0 & 18 \\
\hline Gracilinanus microtarsus & 5 & 0 & 0 & 0 & 0 & 0 & 0 \\
\hline Hylaeamys megacephalus & 6 & 0 & 5 & 9 & 0 & 0 & 10 \\
\hline Monodelphis domestica & 12 & 3 & 5 & 0 & 7 & 0 & 0 \\
\hline
\end{tabular}




\begin{tabular}{lccccccc}
\hline Nasua nasua & 0 & 0 & 0 & 0 & 1 & 0 & 1 \\
Necromys lasiurus & 0 & 0 & 1 & 3 & 0 & 0 & 0 \\
Oecomys aff. mamorae & 12 & 3 & 26 & 3 & 8 & 0 & 5 \\
Oecomys sp. 1 & 0 & 0 & 0 & 0 & 0 & 0 & 8 \\
Oecomys sp. 2 & 0 & 0 & 0 & 0 & 0 & 0 & 2 \\
Thrichomys pachyurus & 23 & 1 & 7 & 0 & 2 & 0 & 1 \\
N.I. & 0 & 0 & 0 & 0 & 10 & 5 & 1 \\
\hline
\end{tabular}

N.I.: espécimes aguardando identificação

No Diagrama de Whittaker (Gráfico 1) o comprimento da curva indica a riqueza de espécies e a inclinação expressa a equidade, (quanto mais inclinada a curva, menor é a equidade entre as espécies).Assim, as curvas mais longas, referentes às áreas $\mathrm{E}$ e $\mathrm{NE}$, representam uma riqueza um pouco maior que nas $\mathrm{BIO}$; por outro lado, a curvatura dos gráficos, mais acentuada para as áreas mais antropizadas, denota que a equabilidade dessas áreas é menor que nas BIO.

Gráfico 1: Diagrama de Whittaker representando riqueza e abundância das espécies de pequenos mamíferos para as áreas de coleta (E, NE e BIO)

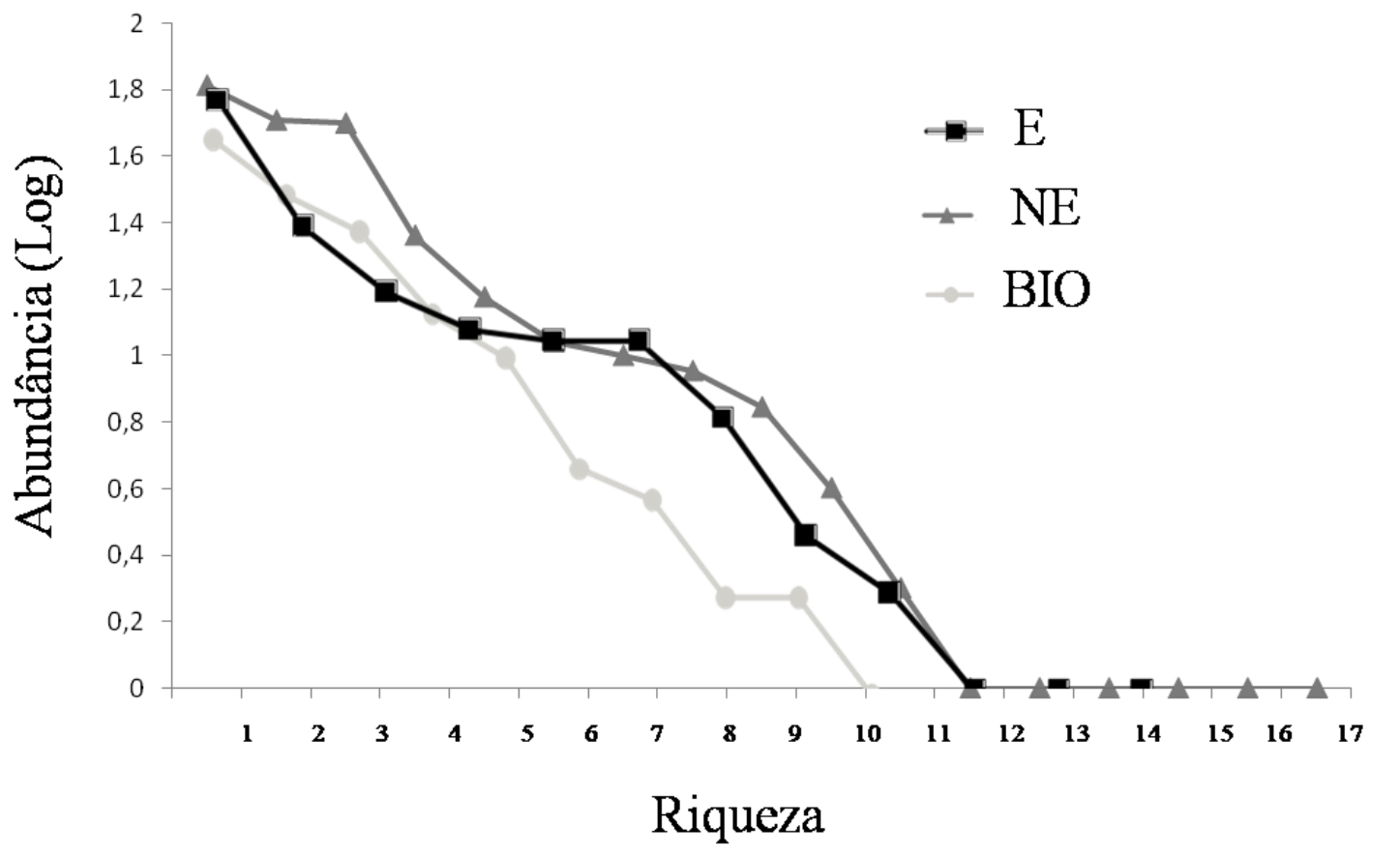




\subsection{Diversidade de Carrapatos e Prevalência de Parasitismo}

Ao fim de todas as campanhas foram coletados 4427 carrapatos, parasitando os pequenos mamíferos capturados, pertencentes a três gêneros e oito espécies distintas. Foram catalogadas quatro espécies de carrapatos nas $\mathrm{E}$, seis nas $\mathrm{NE}$ e quatro nas BIO. De forma geral, as prevalências de carrapatos foram maiores nas áreas endêmicas. Na tabela 2 estão dispostos números totais de mamíferos capturados, bem como de infestados por carrapatos, e sua prevalência de parasitismo para cada área.

Tabela 2. Prevalências de carrapatos em pequenos mamíferos capturados de 2015 a 2018 nas áreas endêmicas com alto grau de antropização (E), não endêmicas com alto grau de antropização (NE) e não endêmicas com baixo grau de antropização (BIO).

\begin{tabular}{cccccccccccc}
\hline & E1 & E2 & E3 & $\mathbf{E}_{\mathbf{T}}$ & BIO1 & BIO2 & BIO $_{\mathbf{T}}$ & NE1 & NE2 & NE3 & NE $_{\mathbf{T}}$ \\
\hline $\begin{array}{c}\text { Hospedeiros } \\
\text { infestados }\end{array}$ & 23 & 38 & 81 & $\mathbf{6 9}$ & 23 & 31 & $\mathbf{5 4}$ & 38 & 54 & 7 & $\mathbf{9 9}$ \\
$\begin{array}{c}\text { Hospedeiros } \\
\text { capturados }\end{array}$ & 32 & 59 & 61 & $\mathbf{1 5 2}$ & 107 & 138 & $\mathbf{2 4 5}$ & 114 & 113 & 27 & $\mathbf{2 5 4}$ \\
$\begin{array}{c}\text { Número de } \\
\text { campanhas }\end{array}$ & 07 & 06 & 06 & $\mathbf{1 9}$ & 06 & 05 & $\mathbf{1 1}$ & 07 & 07 & 01 & $\mathbf{1 5}$ \\
& & & & & & & & & & & \\
Prevalência (\%) & 71,9 & 64,4 & 32,8 & $\mathbf{4 5 , 4}$ & 21,5 & 22,5 & $\mathbf{2 2 , 0}$ & 33,3 & 47,8 & 25,9 & $\mathbf{3 9 , 0}$ \\
\hline
\end{tabular}

E1: campus "Luiz de Queiroz" (ESALQ) em Piracicaba-SP; E2: Estação de Tratamento de Esgoto Carioba em Americana-SP; E3: campus da UFSCar em Araras-SP; NE1: Campus da USP em Pirassununga-SP; NE2: Campus da USP em Ribeirão Preto-SP; NE3: Parque Estadual Alberto Löfgren em São Paulo-SP; BIO1: Pantanal de Poconé, em Poconé-MS; BIO2: Pantanal da Nhecolândia, em Corumbá-MS.

Em relação aos componentes da diversidade de carrapatos, as E apresentaram abundância muito superior no número absoluto de parasitos coletados com um total de 2795 espécimes, enquanto nas NE e nas BIO esse número foi de 1283 e 342 respectivamente. Mesmo considerando a abundância relativa (número de carrapatos/número de campanhas.área), essa proporção se mantém. Foram contabilizados os carrapatos de pequenos mamíferos de 19 campanhas.área das E, 15 das NE, e 11 das BIO, resultando em um número de carrapatos por coleta igual a 147,$1 ; 86,0$ e 31,0 , respectivamente.

O número absoluto de carrapatos coletados na estação seca foi consideravelmente maior em relação à estação chuvosa, sendo o gênero Amblyomma o responsável pela maior soma de espécimes. Com relação às espécies A. sculptum e A. dubitatum foi possível observar 
uma predominância da primeira nas E e nas BIO, e da segunda nas NE respectivamente. A tabela 3 mostra o número de carrapatos coletados por espécie em cada campanha por área.

Tabela 3. Número de carrapatos coletados nos três tipos de área (endêmicas com alto grau de antropização, não endêmicas com alto grau de antropização e não endêmicas com baixo grau de antropização) em cada campanha de captura durante o período de 2015 a 2018

\begin{tabular}{|c|c|c|c|c|c|c|c|}
\hline \multirow[b]{2}{*}{ Espécie Coletada } & \multicolumn{7}{|c|}{ Campanha de Captura } \\
\hline & $\begin{array}{l}\text { Seca } \\
2015\end{array}$ & $\begin{array}{c}\text { Chuva } \\
2015-16\end{array}$ & seca 2016 & $\begin{array}{c}\text { chuva } \\
2016-17\end{array}$ & $\begin{array}{l}\text { seca } \\
2017\end{array}$ & $\begin{array}{c}\text { chuva } \\
2017-18\end{array}$ & seca 2018 \\
\hline \multicolumn{8}{|c|}{ ÁREAS ENDÊMICAS COM ALTO GRAU DE ANTROPIZAÇÃO } \\
\hline Amblyomma spp & 476 & 2 & 896 & 0 & 499 & 49 & 107 \\
\hline Amblyomma sculptum & 278 & 39 & 24 & 0 & 59 & 66 & 145 \\
\hline Amblyomma dubitatum & 71 & 1 & 26 & 0 & 24 & 2 & 15 \\
\hline Amblyomma ovale & 2 & 0 & 0 & 0 & 2 & 0 & 0 \\
\hline Ixode spp & 0 & 0 & 0 & 0 & 5 & 0 & 6 \\
\hline Ixodes loricatus & 0 & 0 & 0 & 0 & 1 & 0 & 0 \\
\hline Total por campanha & 827 & 42 & 946 & 0 & 590 & 117 & 273 \\
\hline \multicolumn{8}{|c|}{$\begin{array}{l}\text { ÁREAS NÃO ENDÊMICAS COM ALTO GRAU DE } \\
\text { ANTROPIZAÇÃO }\end{array}$} \\
\hline Amblyomma spp & 20 & 1 & 489 & 8 & 303 & 87 & 243 \\
\hline Amblyomma sculptum & 2 & 0 & 1 & 1 & 2 & 3 & 4 \\
\hline Amblyomma dubitatum & 29 & 0 & 15 & 3 & 16 & 2 & 15 \\
\hline Amblyomma ovale & 0 & 0 & 2 & 0 & 2 & 0 & 0 \\
\hline Argasidae spp. & 0 & 0 & 0 & 0 & 3 & 0 & 0 \\
\hline Ixodes spp & 5 & 0 & 0 & 0 & 3 & 0 & 7 \\
\hline Ixodes loricatus & 4 & 0 & 1 & 5 & 1 & 7 & 0 \\
\hline Ixodes shulzei & 6 & 0 & 0 & 0 & 0 & 0 & 0 \\
\hline Total por campanha & 66 & 1 & 508 & 17 & 330 & 99 & 269 \\
\hline \multicolumn{8}{|c|}{$\begin{array}{l}\text { ÁREAS NÃO ENDÊMICAS COM BAIXO GRAU DE } \\
\text { ANTROPIZAÇÃO }\end{array}$} \\
\hline Amblyomma spp & 63 & 0 & 22 & 0 & 4 & 0 & 0 \\
\hline Amblyomma sculptum & 64 & 0 & 44 & 0 & 3 & 0 & 0 \\
\hline Amblyomma ovale & 10 & 0 & 1 & 2 & 11 & 0 & 3 \\
\hline Amblyomma parvum & 61 & 0 & 14 & 0 & 10 & 0 & 0 \\
\hline Ixodes loricatus & 0 & 0 & 0 & 2 & 0 & 0 & 0 \\
\hline Ornithodoros mimon & 26 & 0 & 2 & 0 & 0 & 0 & 0 \\
\hline Total por campanha & 224 & 0 & 83 & 4 & 28 & 0 & 3 \\
\hline
\end{tabular}

O número de carrapatos variou entre as estações seca e chuvosa para a maioria das espécies que foram coletadas em maior abundância, nos três tipos de área amostradas $\left(\mathrm{U}_{\mathrm{E}}=\right.$ $\left.116,5, \mathrm{p}=0,008, \mathrm{U}_{\mathrm{NE}}=247,0, \mathrm{p}=0,017, \mathrm{U}_{\mathrm{BIO}}=93,0, \mathrm{p}=0,00\right)$ (figuras 12A, 12B e 12C). 
Figura 12: Número de carrapatos coletados sobre pequenos mamíferos nas estações seca e chuvosa em áreas endêmicas (A), não endêmicas com alto grau de antropização (B) e não endêmicas com baixo grau de antropização (C) para FMB, de 2015 a 2018.
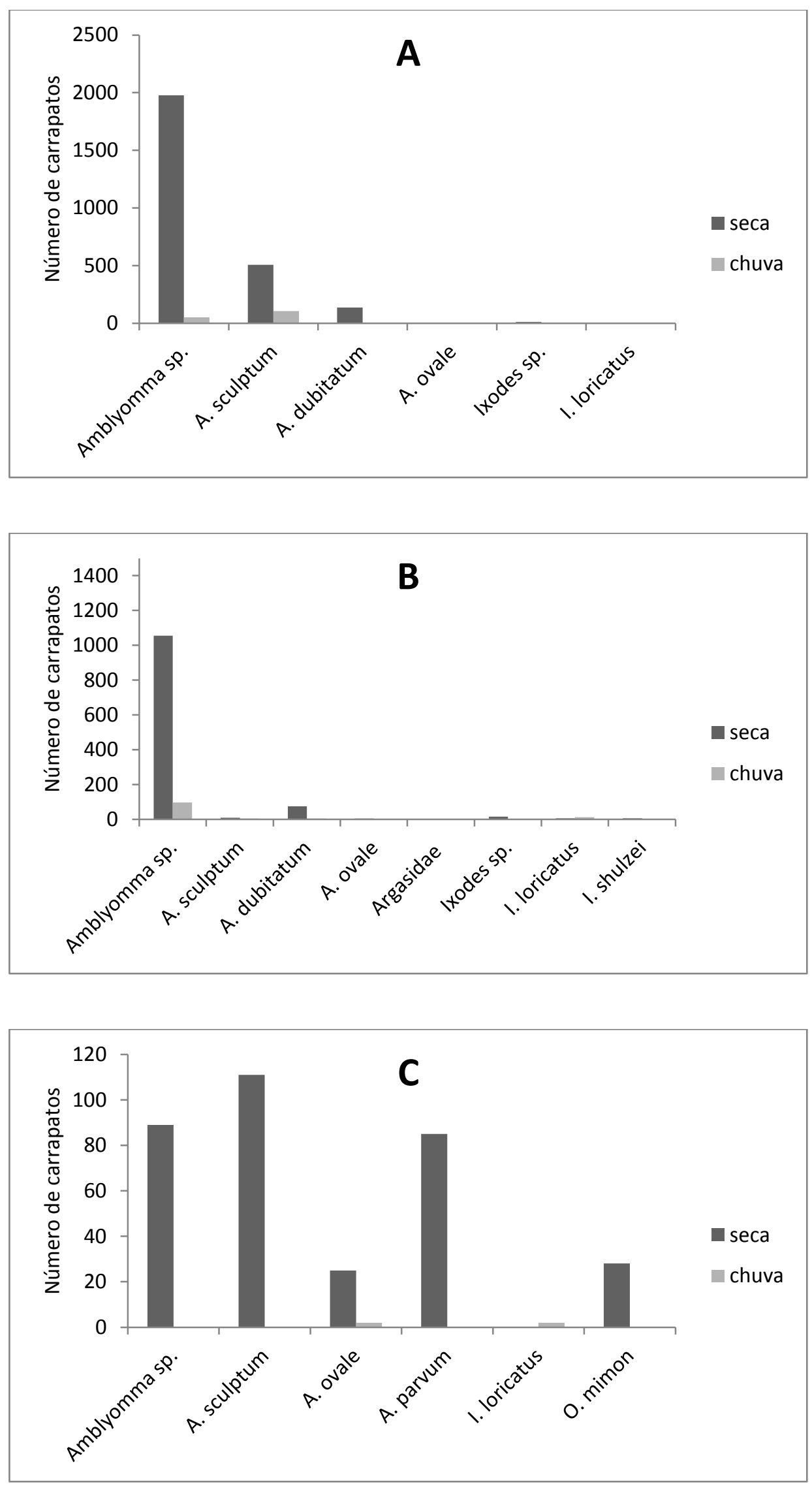
Nas E, onze das 13 espécies de mamíferos capturadas estavam parasitadas por carrapatos $(84,5 \%$ de prevalência). As espécies em que não foram constatados parasitismo durante o período das coletas foram os roedores Euryoryzomys russatus e Mus musculus. Foram coletados 2795 espécimes desses parasitas pertencentes tanto ao gênero Amblyomma (A. sculptum, A. dubitatum e A. ovale) quanto ao gênero Ixodes (I. loricatus). Desse total 2040 eram larvas e foram identificadas apenas até nível genérico. Dos 755 restantes, $81 \%$ foram identificados como A. sculptum e 18,4\% como A. dubitatum. O marsupial $D$. albiventris foi o pequeno mamífero mais parasitado por A. sculptum nessas áreas, uma vez que 527 dos 611 carrapatos dessa espécie foram coletados parasitando um animal dessa espécie. Os dados de infestação de pequenos mamíferos das áreas endêmicas estão apresentados na Tabela 4.

Já nas NE, 11 das 16 espécies de pequenos mamíferos estavam parasitadas $(68,7 \%$ de prevalência). As espécies em que não foram constatados parasitismo durante o período de coleta foram os roedores Juiomys cf assitenuis, Oecomys sp. e Cerradomys sp.; e os marsupiais Micoreus constatinae e Philander sp. Um total de 1283 carrapatos foram coletados, também pertencentes aos gêneros Amblyomma (A. sculptum, A. dubitatum e A. ovale) e Ixodes (I. loricatus e Ixodes schulzei). As larvas eram 1162 espécimes desse total, e A. sculptum e A. dubitatum representaram respectivamente $10,7 \%$ e $66 \%$ dos 121 carrapatos restantes. $\mathrm{O}$ marsupial $D$. albiventis foi mais uma vez a espécie de pequeno mamífero mais parasitada, sendo responsável por abrigar todos os A. sculptum e 60 dos 80 A. dubitatum coletados. Os dados de infestação para as áreas não endêmicas com alto grau de antropização estão apresentados na Tabela 5.

Por fim, nas BIO, foram coletados 342 carrapatos pertencentes aos gêneros Amblyomma (A. sculptum, A. parvum e A. ovale), Ixodes (I. loricatus) e Ornithodoros (Ornithodoros mimon) parasitando 11 das 14 espécies de pequenos mamíferos capturadas (78,6\% de prevalência). As espécies em que não foram constatados parasitismo durante o período das coletas foram os roedores Cerradomys subflavus e Oecomys sp. 1, e o marsupial Gracilinanus microtarsus. Do total de carrapatos coletados, 89 eram larvas de Amblyomma, e dos 253 restantes 43,8\% (111) eram A. sculptum. Diferentemente das demais áreas $A$. dubitatum não teve nenhum espécime coletado durante as campanhas, sendo A. parvum a segunda espécie de maior abundância representando 33,6\% do total de carrapatos identificados. Os dados de infestação nas áreas não endêmicas com baixo grau de antropização está apresentada na Tabela 6. 
Tabela 4. Número total de carrapatos (n) e prevalência (P) em pequenos mamíferos de áreas endêmicas (E) de São Paulo, de 2015 a 2018*

\begin{tabular}{|c|c|c|c|c|c|c|c|c|c|}
\hline \multirow[t]{2}{*}{ Área } & \multirow{2}{*}{$\begin{array}{l}\text { Hospedeiro } \\
\text { (capturados/infestados) }\end{array}$} & $\begin{array}{c}\text { Amblyomma } \\
\text { sp. }\end{array}$ & $\begin{array}{l}\text { Amblyomma } \\
\text { ovale }\end{array}$ & $\begin{array}{c}\text { Amblyomma } \\
\text { sculptum }\end{array}$ & $\begin{array}{c}\text { Amblyomma } \\
\text { dubitatum }\end{array}$ & Ixodes sp. & $\begin{array}{r}\text { Ixodes } \\
\text { loricatus }\end{array}$ & $\begin{array}{c}\text { Total por espécie } \\
\text { hospedeira }\end{array}$ & $\begin{array}{c}\text { Total por } \\
\text { área }\end{array}$ \\
\hline & & \multicolumn{8}{|c|}{$\mathrm{n}(\mathrm{P})$} \\
\hline \multirow{6}{*}{ E1 } & Dasypus novemcinctus $(1 / 1)$ & 0 & 0 & 4 & 0 & 0 & 0 & $4(100 \%)$ & \multirow{6}{*}{$\begin{array}{l}1116 \\
(75 \%)\end{array}$} \\
\hline & Didelphis albiventris $(19 / 17)$ & 779 & 3 & 138 & 8 & 0 & 0 & $928(89,4 \%)$ & \\
\hline & Didelphis aurita $(1 / 1)$ & 104 & 0 & 35 & 0 & 0 & 0 & $139(100 \%)$ & \\
\hline & $\begin{array}{l}\text { Nasua nasua }(1 / 1) \\
\text { Rattus rattus }(1 / 1)\end{array}$ & $\begin{array}{l}2 \\
5\end{array}$ & 0 & 35 & 1 & 0 & 0 & $\begin{array}{l}38(100 \%) \\
5(100 \%)\end{array}$ & \\
\hline & Oligoryzomys nigripes $(8 / 2)$ & 2 & 0 & 0 & 0 & 0 & 0 & $\begin{array}{l}5(100 \%) \\
2(25 \%)\end{array}$ & \\
\hline & & & 0 & 0 & 0 & 0 & 0 & & \\
\hline \multirow{2}{*}{ E2 } & Didelphis albiventris $(38 / 31)$ & 793 & 0 & 254 & 103 & 0 & 0 & $1150(81,5 \%)$ & \multirow{2}{*}{$\begin{array}{c}1197 \\
(70,4 \%)\end{array}$} \\
\hline & Rattus rattus (16/7) & 34 & 0 & 9 & 4 & 0 & 0 & $47(43,7 \%)$ & \\
\hline \multirow{8}{*}{ E3 } & Didelphis albiventris (10/9) & 255 & 1 & 135 & 9 & 0 & 1 & $401(90 \%)$ & \multirow{8}{*}{$\begin{array}{c}482 \\
(36,3 \%)\end{array}$} \\
\hline & Cavia sp. (2/2) & 40 & 0 & 0 & 14 & 0 & 0 & $54(100 \%)$ & \\
\hline & Galictis cuja $(1 / 1)$ & 10 & 0 & 1 & 0 & 0 & 0 & $11(100 \%)$ & \\
\hline & Gracilinanus agilis (7/1) & 0 & 0 & 0 & 0 & 5 & 0 & $5(14,3 \%)$ & \\
\hline & Gracilinanus microtarsus (6/2) & 0 & 0 & 0 & 0 & 6 & 0 & $6(33,3 \%)$ & \\
\hline & Necromys lasiurius(10/2) & 2 & 0 & 0 & 0 & 0 & 0 & $2(20 \%)$ & \\
\hline & Oligoryzomys nigripes $(18 / 2)$ & 2 & 0 & 0 & 0 & 0 & 0 & $2(11,1 \%)$ & \\
\hline & N.I. (1/1) & 1 & 0 & 0 & 0 & 0 & 0 & $1(100 \%)$ & \\
\hline \multicolumn{2}{|r|}{ espécie de carrapato } & 2029 & 4 & 611 & 139 & 11 & 1 & - & - \\
\hline
\end{tabular}

N: número de hospedeiros por espécie; E1: campus "Luiz de Queiroz" (ESALQ) em Piracicaba-SP; E2: Estação de Tratamento de Esgoto Carioba em Americana-SP; E3: campus da UFSCar em Araras-SP. *campanhas: E1 e E2 = seca de 2015, 2016, 2017 e 2018; chuva de 2015-2016, 2016-2017 e 2017-2018; E3: seca de 2015, 2016, 2017 e 2018; chuva de 2016-2017 e 2017-2018 
Tabela 5. Número total de carrapatos (n) e prevalência (P) em espécies de pequenos mamíferos infestados em áreas não endêmicas de baixa diversidade (NE) de São Paulo, de 2015 a $2018^{*}$

\begin{tabular}{|c|c|c|c|c|c|c|c|c|c|c|}
\hline & Hospedeiro $(\mathrm{N})$ & $\begin{array}{c}\text { Ixodes } \\
\text { sp. }\end{array}$ & $\begin{array}{c}\text { Ixodes } \\
\text { schulzei }\end{array}$ & $\begin{array}{c}\text { Ixodes } \\
\text { loricatus }\end{array}$ & $\begin{array}{l}\text { Amblyomma } \\
\text { sp. }\end{array}$ & $\begin{array}{c}\text { Amblyomma } \\
\text { ovale }\end{array}$ & $\begin{array}{c}\text { Amblyomma } \\
\text { sculptum }\end{array}$ & $\begin{array}{c}\text { Amblyomma } \\
\text { dubitatum }\end{array}$ & $\begin{array}{c}\text { Total por } \\
\text { hospedeiro }\end{array}$ & $\begin{array}{l}\text { Total por } \\
\text { área }\end{array}$ \\
\hline \multirow{8}{*}{ NE1 } & Akodon sp. (6/1) & 0 & 0 & 0 & 1 & 0 & 0 & 0 & $1(16,7 \%)$ & \multirow{8}{*}{$613(40,9 \%)$} \\
\hline & Cavia sp. (1/1) & 0 & 0 & 0 & 3 & 0 & 0 & 1 & $4(100 \%)$ & \\
\hline & Didelphis albiventris $(25 / 20)$ & 0 & 0 & 0 & 536 & 1 & 3 & 29 & $569(80 \%)$ & \\
\hline & Necromys lasiurus (1/1) & 0 & 0 & 0 & 1 & 0 & 0 & 0 & $1(100 \%)$ & \\
\hline & Gracilinanus agilis (19/1) & 0 & 0 & 0 & 1 & 0 & 0 & 0 & $1(5,2 \%)$ & \\
\hline & Hylaeamys megacephalus (6/3) & 0 & 0 & 0 & 2 & 1 & 0 & 0 & $3(50 \%)$ & \\
\hline & Nectomys squamipes (7/4) & 0 & 0 & 0 & 13 & 0 & 0 & 0 & $13(57,1 \%)$ & \\
\hline & Oligoryzomys nigripis(28/7) & 0 & 0 & 0 & 18 & 2 & 0 & 1 & $21(25 \%)$ & \\
\hline \multirow{8}{*}{ NE2 } & Akodon sp. (3/1) & 0 & 0 & 0 & 2 & 0 & 0 & 0 & $2(33,3 \%)$ & \multirow{8}{*}{$652(47,3 \%)$} \\
\hline & Didelphis albiventris(41/29) & 0 & 0 & 15 & 455 & 0 & 10 & 31 & $511(70,8 \%)$ & \\
\hline & Gracilinanus agilis (19/3) & 8 & 0 & 0 & 0 & 0 & 0 & 0 & $8(15,7 \%)$ & \\
\hline & Hylaeamys megacephalus (1/1) & 0 & 0 & 0 & 1 & 0 & 0 & 0 & $1(100 \%)$ & \\
\hline & Nectomys squamipes (16/8) & 0 & 0 & 0 & 63 & 0 & 0 & 7 & $70(50 \%)$ & \\
\hline & Oligoryzomys nigripes (22/9) & 7 & 6 & 1 & 24 & 0 & 0 & 1 & $38(41 \%)$ & \\
\hline & Rattus rattus $(11 / 2)$ & 0 & 0 & 0 & 11 & 0 & 0 & 0 & $11(18 \%)$ & \\
\hline & N.I. (1/1) & 0 & 0 & 0 & 11 & 0 & 0 & & $11(100 \%)$ & \\
\hline \multirow[t]{2}{*}{ NE3 } & Didelphis aurita (10/5) & 0 & 0 & 2 & 8 & 0 & 0 & 4 & $14(50 \%)$ & \multirow[t]{2}{*}{$25(36,8 \%)$} \\
\hline & Euryoryzomys russatus $(9 / 2)$ & 0 & 0 & 0 & 1 & 0 & 0 & 6 & $7(22,2 \%)$ & \\
\hline Total de & ie de carrapato & 11 & 6 & 18 & 1151 & 4 & 13 & 80 & - & \\
\hline
\end{tabular}

N: número de hospedeiros por espécie; NE1: Campus da USP em Pirassununga-SP; NE2: Campus da USP em Ribeirão Preto-SP; NE3: Parque Estadual Alberto Löfgren em São Paulo-SP. *campanhas: NE1 e NE2 = seca de 2015, 2016, 2017 e 2018; chuva de 2015-2016, 2016-2017 e 2017-2018; NE3: seca de 2015 e 2017; chuva de 2015-2016 e 20162017 
Tabela 6. Número total de carrapatos (n) e prevalência (P) em pequenos mamíferos de áreas não-endêmicas de alta diversidade (BIO) nos estados do Mato Grosso e Mato Grosso do Sul, de 2015 a $2018^{*}$

\begin{tabular}{|c|c|c|c|c|c|c|c|c|c|}
\hline \multirow[t]{2}{*}{ Área } & \multirow[t]{2}{*}{ Hospedeiro $(\mathrm{N})$} & \multirow[t]{2}{*}{$\begin{array}{c}\text { Ixodes } \\
\text { loricatus }\end{array}$} & $\begin{array}{l}\text { Amblyomma } \\
\text { sp. }\end{array}$ & $\begin{array}{c}\text { Amblyomma } \\
\text { ovale }\end{array}$ & $\begin{array}{c}\text { Amblyomma } \\
\text { sculptum }\end{array}$ & $\begin{array}{c}\text { Amblyomma } \\
\text { parvum }\end{array}$ & $\begin{array}{c}\text { Ornithodoros cf. } \\
\text { mimon }\end{array}$ & $\begin{array}{c}\text { Total por } \\
\text { hospedeiro }\end{array}$ & \multirow[t]{2}{*}{ Total por área } \\
\hline & & & \multicolumn{6}{|c|}{$\mathrm{n}(\mathrm{P})$} & \\
\hline \multirow{8}{*}{ BIO1 } & Oecomys aff. mamorae (11/1) & 0 & 1 & 0 & 3 & 0 & 0 & $4(9 \%)$ & \multirow{8}{*}{$205(21,9 \%)$} \\
\hline & Oecomyssp.2 (2/1) & 0 & 0 & 1 & 0 & 0 & 0 & $1(50 \%)$ & \\
\hline & Didelphis albiventris (1/1) & 2 & 0 & 2 & 0 & 0 & 0 & $4(100 \%)$ & \\
\hline & Dasyprocta azarae (4/4) & 0 & 20 & 1 & 105 & 0 & 0 & $126(100 \%)$ & \\
\hline & Gracilinanus agilis $(9 / 2)$ & 0 & 0 & 0 & 0 & 0 & 25 & $25(33,3 \%)$ & \\
\hline & Hylaeamys megacephalus (30/12) & 0 & 26 & 15 & 0 & 0 & 1 & $42(40 \%)$ & \\
\hline & Necromys lasiurus $(4 / 1)$ & 0 & 1 & 0 & 0 & 0 & 0 & $1(25 \%)$ & \\
\hline & N.I $(16 / 1)$ & 0 & 0 & 2 & 0 & 0 & 0 & $2(6,5 \%)$ & \\
\hline \multirow{6}{*}{$\mathrm{BIO} 2$} & Clyomys laticeps $(2 / 2)$ & 0 & 1 & 0 & 0 & 1 & 0 & $2(100 \%)$ & \multirow{6}{*}{$137(25,2 \%)$} \\
\hline & Gracilinanus agilis $(6 / 1)$ & 0 & 3 & 0 & 0 & 0 & 0 & $3(16,6 \%)$ & \\
\hline & Monodelphis domestica (27/1) & 0 & 0 & 0 & 0 & 0 & 1 & $1(3,7 \%)$ & \\
\hline & Nasua nasua $(2 / 1)$ & 0 & 0 & 0 & 3 & 0 & 0 & $3(50 \%)$ & \\
\hline & Oecomys aff. mamorae(49/4) & 0 & 1 & 0 & 0 & 3 & 1 & $5(8,1 \%)$ & \\
\hline & Thrichomys pachyurus $(37 / 22)$ & 0 & 36 & 6 & 0 & 81 & 0 & $123(59,4 \%)$ & \\
\hline \multicolumn{2}{|c|}{ Total de cada espécie de carrapato } & 2 & 89 & 27 & 111 & 85 & 28 & & \\
\hline
\end{tabular}

N: número de hospedeiros por espécie; BIO1: Pantanal de Poconé, em Poconé-MS; BIO2: Pantanal da Nhecolândia, em Corumbá-MS. *campanhas: BIO1 = seca de 2015, 2016, 2017 e 2018; chuva de, 2016-2017 e 2017-2018; BIO2: seca de 2015, 2016 e 2017; chuva de 2015-2016 (parcial) 
O carrapato A. sculptum foi coletado parasitando pequenos mamíferos em quantidade muito superior nas E que nas demais áreas, sendo o gambá de orelha branca $(D$. albiventris) o principal hospedeiro para essa espécie nas E e NE (Figura 2A). Já nas BIO nenhum individuo dessa espécie capturado estava infestado por A. sculptum. Apesar de haver variação nos números, o padrão de infestação por outras espécies de carrapatos se manteve similar àquele observado para A. sculptum, com a maioria sendo observada sobre D. albiventris nas E e NE, mas não nas BIO (Figura 2B).

Figura 13: Número de carrapatos A. sculptum (A) e de outras espécies (B) infestando o gambá de orelha branca (D. albiventris) em comparação com os demais pequenos mamíferos (roedores e marsupiais) capturados em áreas endêmicas (E1, E2 e E3), áreas não-endêmicas com alto grau de antropização (NE1, NE2 e NE3) e áreas não-endêmicas com menor grau de antropização (BIO1 e BIO2), de 2015 a 2018. Foram excluídas as larvas identificadas apenas como Amblyomma sp.
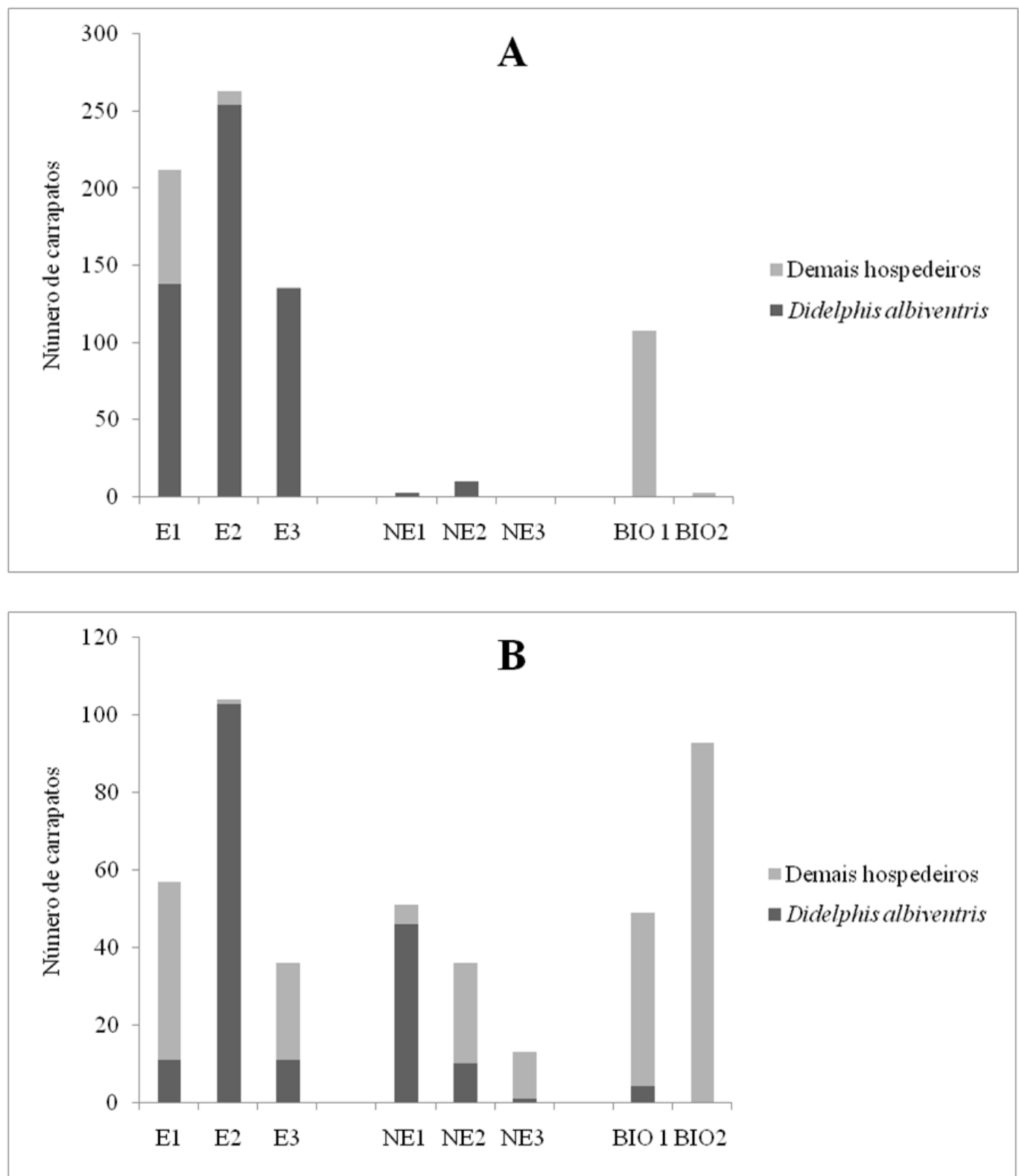


\subsection{Sorologia para detecção de anticorpos anti-Rickettsia}

Ao todo foram testados os soros de 561 animais, sendo 132 das E, 240 das NE e 190 das BIO. Os soros pertencentes às espécies Dasypus novemcintus, Dasyprocta azarae, Galictis cuja e Nasua nasua não foram testados por não haver conjugado compatível. Não foram testadas também 18 amostras em que não houve identificação do animal nem em nível de ordem, e 37 que não continham soro suficiente para realizar a reação. Os resultados da sorologia para cricetídeos, murídeos, equimídeos e didelfídeos de cada uma das áreas estão apresentados na Tabela 7.

Para os roedores, 33,3\% dos animais apresentaram títulos para Rickettsia nas áreas endêmicas com alto grau de antropização, 15,7\% nas áreas não endêmicas com alto grau de antropização e $12,6 \%$ nas áreas não endêmicas com baixo grau de antropização. Para os marsupiais a porcentagem foi de 19,2\% (E), 10,3\% (NE) e 11,2\% (BIO). Na tabela 7 estão descritas as amostras reativas em cada área para cada espécie, bem como prováveis antígenos causadores da infecção. 
Tabela 7. Sororreatividade de pequenos mamíferos coletados em áreas endêmicas com alto grau de antropização, não-endêmicas com alto grau de antropização e não-endêmicas com baixo grau de antropização.

\begin{tabular}{|c|c|c|c|c|c|c|c|}
\hline \multirow[t]{2}{*}{$\begin{array}{l}\text { Área de } \\
\text { coleta }\end{array}$} & \multirow{2}{*}{$\begin{array}{l}\text { Espécies de pequenos } \\
\text { mamíferos } \\
\left(\mathrm{n}^{\mathrm{o}} \text { de animais testados) }\right.\end{array}$} & \multicolumn{5}{|c|}{$\begin{array}{l}\mathrm{N}^{\circ} \text { de animais reativos para cada espécies de riquétsia } \\
(\% \text { sororreatividade) }\end{array}$} & \multirow[t]{2}{*}{$\begin{array}{l}\mathrm{N}^{\mathrm{o}} \text { de animais com reação homólogi } \\
\text { detectada }^{a}\end{array}$} \\
\hline & & R. rickettsii & R. parkeri & R. rhipicephali & R. amblyommatis & R. bellii & \\
\hline \multirow{4}{*}{ E1 } & Didelphis albiventris (18) & $6(33)$ & $6(33)$ & $6(33)$ & $7(39)$ & $8(39)$ & $\begin{array}{l}3(\text { R. rickettsii }) ; 1(R . \\
\text { amblyommatis }) ; 2(R . \text { bellii })\end{array}$ \\
\hline & Didelphis aurita (1) & 0 & 0 & 0 & 0 & $1(100)$ & 1 (R. bellii) \\
\hline & Oligoryzomys nigripes (6) & 0 & 0 & 0 & 0 & 0 & 0 \\
\hline & Rattus rattus (1) & $1(100)$ & $1(100)$ & $1(100)$ & $1(100)$ & $1(100)$ & 0 \\
\hline \multirow{5}{*}{ E2 } & Didelphis albiventris (37) & 0 & 0 & 0 & 0 & $3(8)$ & 3 (R. bellii) \\
\hline & Gracilinanus microtarsus (1) & 0 & 0 & 0 & 0 & 0 & 0 \\
\hline & Mus musculus (1) & 0 & 0 & 0 & 0 & 0 & 0 \\
\hline & Oligoryzomys nigripes (1) & 0 & 0 & 0 & 0 & 0 & 0 \\
\hline & Rattus rattus (11) & $10(91)$ & $10(91)$ & $11(100)$ & $10(91)$ & $9(82)$ & 0 \\
\hline \multirow{9}{*}{ E3 } & Cavia sp. (2) & 0 & 0 & 0 & 0 & $2(100)$ & $2($ R. bellii $)$ \\
\hline & Didelphis albiventris (8) & $1(12)$ & $1(12)$ & $1(12)$ & $1(12)$ & $1(12)$ & 1 (R. bellii) \\
\hline & Euryoryzomys sp. (4) & 0 & 0 & 0 & 0 & 0 & 0 \\
\hline & Gracilinanus agilis (7) & 0 & 0 & 0 & 0 & 0 & 0 \\
\hline & Gracilinanus microtarsus (6) & $1(16)$ & $1(16)$ & $1(16)$ & $1(16)$ & 0 & 1 (R. parkeri) \\
\hline & Necromys lasiurus (10) & $6(60)$ & $1(10)$ & $6(60)$ & $2(20)$ & $1(10)$ & 1 (R. ricketsii); 1 (R. rhipicephai \\
\hline & Oligoryzomys nigripes (17) & 0 & 0 & 0 & 0 & 0 & 0 \\
\hline & N.I. (3) & 0 & 0 & 0 & 0 & 0 & 0 \\
\hline & TOTAL (132) & $25(18)$ & $20(15)$ & $26(19)$ & $22(16)$ & $26(19)$ & \\
\hline
\end{tabular}




\begin{tabular}{|c|c|c|c|c|c|c|c|}
\hline & Akodon sp. (5) & $2(40)$ & 0 & $1(20)$ & 0 & $1(20)$ & 1 (R. rickettsii); 1 (R. bellii) \\
\hline & Cavia sp. (1) & 0 & 0 & 0 & 0 & $1(100)$ & 1 (R. bellii) \\
\hline & Didelphis albiventris (25) & 0 & 0 & 0 & 0 & $1(4)$ & 1 (R. bellii) \\
\hline & Gracilinanus agilis (30) & 0 & 0 & 0 & 0 & $1(3)$ & 1 (R. bellii) \\
\hline & Hylaeamys megacephalus (6) & 0 & 0 & 0 & 0 & 0 & 0 \\
\hline & Juliomys cf. ossitenuis (2) & $1(50)$ & 0 & 0 & 0 & 0 & $1($ R. rickettsii) \\
\hline \multirow[t]{11}{*}{ NE1 } & Micoureus sp. (2) & 0 & 0 & 0 & 0 & 0 & 0 \\
\hline & Necromys lasiurus (1) & 0 & 0 & 0 & 0 & 0 & 0 \\
\hline & Nectomys squamipes (5) & 0 & 0 & 0 & 0 & 0 & 0 \\
\hline & Oecomys mamorae (1) & 0 & 0 & 0 & 0 & 0 & 0 \\
\hline & Oligoryzomys nigripes (23) & 0 & 0 & $2(9)$ & 0 & 0 & $2($ R. rhipicephali) \\
\hline & Oryzomys sp. (1) & 0 & 0 & 0 & 0 & 0 & 0 \\
\hline & Philander sp. (1) & 0 & 0 & 0 & 0 & 0 & 0 \\
\hline & Akodon sp. (3) & 0 & 0 & 0 & 0 & 0 & 0 \\
\hline & Didelphis albiventris (40) & $3(7)$ & $1(2)$ & $1(2)$ & $1(2)$ & $3(7)$ & $3($ R. rickettsii); 2 (R. bellii) \\
\hline & Gracilinanus agilis (9) & 0 & 0 & 0 & 0 & $1(11)$ & 1 (R. bellii) \\
\hline & Gracilinanus microtarsus (10) & 0 & 0 & 0 & 0 & 0 & 0 \\
\hline \multirow[t]{7}{*}{ NE2 } & Hylaeamys megacephalus (1) & 0 & 0 & 0 & 0 & 0 & 0 \\
\hline & Nectomys squamipes (16) & $1(6)$ & 0 & 0 & 0 & 0 & $1($ R. rickettsii $)$ \\
\hline & Oligoryzomys nigripes (22) & 0 & 0 & 0 & 0 & $1(4)$ & 1 (R. bellii) \\
\hline & Rattus rattus (10) & $9(90)$ & $4(40)$ & $8(80)$ & $6(60)$ & $8(80)$ & 1 (R. rickettsii); 1 (R. bellii) \\
\hline & N.I. (1) & 0 & 0 & 0 & 0 & 0 & 0 \\
\hline & Akodon sp. (6) & $1(16)$ & 0 & $1(16)$ & 0 & 0 & 0 \\
\hline & Didelphis aurita (9) & $2(22)$ & $1(11)$ & $1(11)$ & $1(11)$ & $4(44)$ & $1($ R.. rickettsii $) ; 4(R$. bellii $)$ \\
\hline
\end{tabular}




\begin{tabular}{|c|c|c|c|c|c|c|c|}
\hline \multirow[t]{3}{*}{ NE3 } & Euryoryzomys russatus (9) & 0 & 0 & 0 & 0 & 0 & 0 \\
\hline & Micoureus constantinae (2) & 0 & 0 & 0 & 0 & 0 & 0 \\
\hline & TOTAL (240) & $19(8)$ & $6(2)$ & $14(6)$ & $8(3)$ & $21(9)$ & \\
\hline \multirow{9}{*}{ BIO1 } & Cerradomys subflavus (1) & 0 & 0 & 0 & 0 & 0 & 0 \\
\hline & Ddidelphis albiventris (1) & 0 & 0 & 0 & 0 & 0 & 0 \\
\hline & Gracilinanus agilis (28) & 0 & 0 & 0 & 0 & $2(7)$ & $2($ R. bellii) \\
\hline & Hylaeamys megacephalus (30), & $1(3)$ & $3(10)$ & $1(3)$ & $1(3)$ & 0 & 2 (R. parkeri) \\
\hline & Necromys lasiurus (4) & 0 & 0 & 0 & 0 & 0 & 0 \\
\hline & Oecomys aff. mamorae (11) & 0 & 0 & 0 & 0 & 0 & 0 \\
\hline & Oecomys sp. 1 (8) & 0 & 0 & 0 & 0 & 0 & 0 \\
\hline & Oecomys sp. 2 (2) & 0 & 0 & 0 & 0 & 0 & 0 \\
\hline & N.I. Rodentia (2) & 0 & 0 & 0 & 0 & 0 & 0 \\
\hline \multirow{7}{*}{$\mathrm{BIO} 2$} & Clyomis laticeps (1) & $1(100)$ & $1(100)$ & $1(100)$ & $1(100)$ & $1(100)$ & 0 \\
\hline & Gracilinanus agilis (5) & 0 & 0 & 0 & 0 & $1(20)$ & 1 (R. bellii) \\
\hline & Gracilinanus microtarsus (4) & 0 & 0 & 0 & 0 & 0 & 0 \\
\hline & Monodelphis domestica (26) & $1(4)$ & $1(4)$ & 0 & 0 & $4(15)$ & 3 (R. bellii) \\
\hline & Oecomys aff. mamorae (45) & 0 & 0 & 0 & 0 & 0 & 0 \\
\hline & Thrichomys pachyurus (28) & $8(28)$ & $4(14)$ & $9(32)$ & $1(3)$ & $10(38)$ & $4($ R. bellii $)$ \\
\hline & TOTAL (189) & $11(6)$ & $8(4)$ & $11(6)$ & $3(1)$ & $17(9)$ & \\
\hline
\end{tabular}

${ }^{a} \mathrm{O}$ antígeno homóloga foi determinado quando um título final para uma espécie de Rickettsia era pelo menos 4 vezes maior do que aqueles observados para as outras espécies de Rickettsia. Neste caso, as espécies de Rickettsia (ou uma espécie muito relacionada) envolvidas no título mais alto foram consideradas o possível antígeno envolvido na resposta sorológica. E1: campus "Luiz de Queiroz" (ESALQ) em Piracicaba-SP; E2: Estação de Tratamento de Esgoto Carioba em Americana-SP; E3: campus da UFSCar em Araras-SP; NE1: Campus da USP em Pirassununga-SP; NE2: Campus da USP em Ribeirão Preto-SP; NE3: Parque Estadual Alberto Löfgren em São Paulo-SP; BIO1: Pantanal de Poconé, em Poconé-MS; BIO2: Pantanal da Nhecolândia, em Corumbá-MS. 


\subsection{Análises Moleculares}

No total 1146 amostras de tecido de baço, fígado e pulmão de 382 pequenos mamíferos de todas as áreas tiveram DNA extraído e foram testadas por PCR Real Time. Apenas 15 foram positivas para o gene gltA distribuídas da seguinte forma: pulmão - sete das E, cinco das NE e uma das BIO; baço - uma das E e uma das NE. Destas 15 amostras, duas foram positivas para o gene gltA pela PCR convencional, uma de pulmão (NE) e uma de baço (E), porém foi possível obter sequência somente da amostra de baço da área endêmica, sendo a mesma 100\% idêntica a Rickettsia felis (MG952933.1). Nenhuma amostra foi positiva para PCR ompA.

Além das amostras de tecido, também foram extraídas e testadas na PCR Real Time 143 amostras de sangue de gambá de todas as áreas, sendo todas negativas. Essas amostras de sangue mais as de tecido que foram negativas na PCR real Time foram testadas na PCR convencional para o gene Citocromo B de mamífero, sendo todas positivas comprovando a eficácia do processo de extração de DNA.

Um total de 615 carrapatos divididos em 239 amostras foram testadas na PCR Real Time, dessas 109 eram provenientes das E, 58 das NE e 72 das BIO. Nas E, 15 amostras foram positivas na PCR real Time (13,8\% de prevalência de infecção), sendo que duas eram compostas de A. sculptum, oito de A. dubitatum e cinco de Ixodes sp. com prevalência de infecção de 2,9\%; 25,8\% e 100\% respectivamente por espécie de carrapato. Dessas, cinco foram positivas na PCR convencional CS2 para gltA, nenhuma amostra foi positiva na PCR ompA, e três foram positivas na PCR específica para Rickettsia bellii. Foi possível sequenciar o agente somente de duas amostras, ambas compostas de A. dubitatum sendo as duas $100 \%$ idênticas a Rickettsia bellii (CP000087).

Nas NE o número de amostras positivas na PCR Real Time foi de 14 (24,1\% de prevalência de infecção) e destas, cinco eram constituídas de A. dubitatum (15,1\%), duas de Ixodes schulzei (40\%), três de Ixodes loricatus (100\%) e quatro de Ixodes sp. (100\%). Somente duas amostras foram positivas na PCR convencional CS2 sendo as duas positivas também na PCR específica para $R$. bellii. Apenas uma amostra de Ixodes sp. foi seqüenciada sendo $100 \%$ idêntica a $R$. bellii (CP000087). Nenhuma amostra foi positiva na PCR ompA.

Já nas BIO, 35 (48,6\%) amostras foram positivas na PCR Real Time, sendo uma composta de A. sculptum (4\%), cinco de A. ovale (38,4\%), 28 de A. parvum $(93,3 \%)$ e uma 
de Argasidae (33,33\%). Destas, 22 foram positivas na PCR CS2, cinco na PCR ompA e apenas uma na PCR específica para $R$. bellii. Foi possível obter sequências da amostra de A. sculptum $100 \%$ idêntica a Rickettsia amblyommatis (KM245156) e de duas amostras de A. parvum, ambas $100 \%$ idênticas a Candidatus Rickettsia andeanae (KF030932). As espécies de carrapato e os hospedeiros de origem das amostras positivas estão discriminados na Tabela 8. 
Tabela 8. Infecção por riquétsias em carrapatos coletados em pequenos mamíferos nas áreas endêmicas com alto grau de antropização (E), não endêmicas com alto grau de antropização (NE) e não endêmicas com baixo grau de antropização (BIO) entre 2015 e 2018

\begin{tabular}{|c|c|c|c|c|c|}
\hline Área de coleta & Espécie de carrapatos & Hospedeiro & $\begin{array}{l}\mathrm{N}^{\circ} \text { de carrapatos } \\
\text { testados por PCR }\end{array}$ & $\begin{array}{l}\mathrm{N}^{\circ} \text { de carrapato } \\
\text { infectados }(\%)\end{array}$ & $\begin{array}{l}\text { Espécies de Rickettsia } \\
\quad\left(\mathrm{n}^{\mathrm{o}} \text { de carrapatos }\right)\end{array}$ \\
\hline \multirow{7}{*}{ E1 } & Amblyomma sculptum & Didelphis albiventris & 13 & 0 & - \\
\hline & & Didelphis aurita & 1 & 0 & - \\
\hline & & Dasypus novemcinctus & 1 & 0 & - \\
\hline & & Nasua nasua & 2 & 0 & - \\
\hline & Amblyomma dubitatum & Didelphis albiventris & 5 & 0 & - \\
\hline & & Nasua nasua & 1 & 0 & - \\
\hline & Amblyomma ovale & Didelphis albiventris & 3 & 0 & - \\
\hline \multirow{4}{*}{ E2 } & Amblyomma sculptum & Didelphis albiventris & 38 & $1(2,6)^{\mathrm{a}}$ & - \\
\hline & & Rattus rattus & 3 & 0 & - \\
\hline & Amblyomma dubitatum & Didelphis albiventris & 12 & $4(33,3)^{\mathrm{a}}$ & - \\
\hline & & Rattus rattus & 3 & $1(33,3)^{\mathrm{a}}$ & R. bellii (1) \\
\hline \multirow{9}{*}{ E3 } & Amblyomma sculptum & Didelphis albiventris & 10 & $1(10)^{\mathrm{a}}$ & - \\
\hline & & Galictis cuja & 1 & 0 & - \\
\hline & Amblyomma dubitatum & Didelphis albiventris & 6 & $2(33,3)^{\mathrm{a}}$ & R. bellii (1) \\
\hline & & Cavia sp. & 4 & $1(25)^{\mathrm{a}}$ & - \\
\hline & Amblyomma ovale & Didelphis albiventris & 1 & 0 & - \\
\hline & Ixodes sp. & Gracilinanus agilis & 3 & $3(100)^{\mathrm{a}}$ & - \\
\hline & & Gracilinanus microtarsus & 2 & $2(100)^{\mathrm{a}}$ & - \\
\hline & Amblyomma sculptum & Didelphis albiventris & 2 & 0 & - \\
\hline & Amblyomma dubitatum & Didelphis albiventris & 9 & $1(11,1)^{\mathrm{a}}$ & - \\
\hline
\end{tabular}




\begin{tabular}{|c|c|c|c|c|c|}
\hline \multirow[t]{4}{*}{ NE1 } & \multirow{4}{*}{ Amblyomma ovale } & Cavia sp. & 1 & 0 & - \\
\hline & & Didelphis albiventris & 1 & 0 & - \\
\hline & & Hylaeamys megacephalus & 1 & 0 & - \\
\hline & & Oligoryzomys nigripes & 1 & 0 & - \\
\hline \multirow{10}{*}{ NE2 } & Amblyomma sculptum & Didelphis albiventris & 8 & 0 & - \\
\hline & \multirow[t]{3}{*}{ Amblyomma dubitatum } & Didelphis albiventris & 16 & $3(18,7)^{\mathrm{a}}$ & - \\
\hline & & Nectomys squamipes & 3 & $1(33,3)^{\mathrm{a}}$ & - \\
\hline & & Oligoryzomys nigripes & 1 & 0 & - \\
\hline & \multirow[t]{2}{*}{ Ixodes loricatus } & Didelphis albiventris & $2^{\mathrm{b}}$ & $2(100)^{\mathrm{a}}$ & - \\
\hline & & Oligoryzomys nigripes & 1 & $1(100)^{\mathrm{a}}$ & - \\
\hline & Ixodes schulzei & Oligoryzomys nigripes & 5 & $2(40)^{\mathrm{a}}$ & - \\
\hline & \multirow[t]{3}{*}{ Ixodes sp. } & Galictis agilis & 1 & $1(100)^{\mathrm{a}}$ & - \\
\hline & & Gracilinanus microtarsus & 2 & $2(100)^{\mathrm{a}}$ & R. bellii (1) \\
\hline & & Oligoryzomys nigripes & 1 & $1(100)^{\mathrm{a}}$ & - \\
\hline \multirow[t]{4}{*}{ NE3 } & Amblyomma dubitatum & Didelphis aurita & 3 & 0 & - \\
\hline & Amblyomma sculptum & Dasyprocta azarae & 20 & $1(5)^{\mathrm{a}}$ & R. amblyommatis (1) \\
\hline & & Oecomys mamorae & 1 & 0 & - \\
\hline & Amblyomma ovale & Dasyprocta azarae & 1 & 0 & - \\
\hline \multirow[t]{6}{*}{$\mathrm{BIO} 1$} & & Hylaeamys megacephalus & 2 & $2(100)^{\mathrm{a}}$ & - \\
\hline & & n.i. & 6 & $3(50)^{\mathrm{a}}$ & - \\
\hline & Ixodes sp. & n.i. & 1 & 0 & - \\
\hline & Argasidae & Gracilinanus agilis & $3^{b}$ & $1(100)^{\mathrm{a}}$ & - \\
\hline & Amblyomma sculptum & Oecomys mamorae & 2 & 0 & - \\
\hline & & Nasua nasua & 1 & 0 & - \\
\hline
\end{tabular}




\begin{tabular}{cllccc} 
& & Oecomys mamorae & 1 & 0 & - \\
BIO2 & Amblyomma ovale & Thrichomys pachyurus & 4 & 0 & - \\
& Amblyomma. parvum & Clyomis laticeps & 1 & $1(100)^{\mathrm{a}}$ & - \\
& & Oecomys mamorae & 1 & $1(100)^{\mathrm{a}}$ & - \\
& & Thrichomys pachyurus & 28 & $26(92,9)^{\mathrm{a}}$ & 'Ca. R. andeanae' (2) \\
\hline
\end{tabular}

${ }^{a} \%$ valor refere-se à taxa mínima de infecção, uma vez que os carrapatos foram testados em pools de até 10 carrapatos, cada pool de um hospedeiro individual diferente. ${ }^{\mathrm{b}}$ referese a uma amostra que contém um espécime adulto 


\subsection{Estrutura de Hábitat}

Por questões logísticas foi possível a avaliação seriada apenas nas áreas mais antropizadas, assim, as comparações referem-se às E e NE e são análises para cada variável em separado (estatística univariada).

Das seis variáveis analisadas, houve diferença significativa entre as E e as NE apenas em uma delas; complexidade de sub-bosque até $2 \mathrm{~m}$ de altura $(\mathrm{U}=8.371,5$ e $\mathrm{P}=$ $0,000)$ sendo as NE com maior complexidade.

Não houve diferença estatística nas variáveis cobertura do dossel (U=12,677 e P= 0,732), plantas com diâmetro menor que $14 \mathrm{~cm}$ e altura maior que $50 \mathrm{~cm}(\mathrm{U}=476,5 \mathrm{e} \mathrm{P}=$ 0,386) e número de regenerantes ( $\mathrm{U}=428,0$ e $\mathrm{P}=0,066)$, profundidade da serapilheira ( $\mathrm{U}=$ 13.192,0 e $\mathrm{P}=0,929)$ indicando maior profundidade nas $\mathrm{E}$, peso da serapilheira $(\mathrm{U}=$ $11.590,5$ e $\mathrm{P}=0,734$ ) indicando maior peso do material nas $\mathrm{E}$, e A tabela 9 mostra os resultados encontrados para todas as variáveis aferidas nas E e NE.

A partir dos dados de temperatura e umidade relativa ao nível do solo, nas trilhas em que também foram coletados carrapatos em vida livre, e onde foram colocadas as armadilhas para captura de pequenos mamíferos, foi calculado o déficit hídrico das E e das NE (tabela 10).

As análises de cada estação em separado (verão $\mathrm{x}$, seca $\mathrm{y}$, verão $\mathrm{z}$, seca $\mathrm{w}$ ) mostraram um padrão para a mesma estação climática. Durante a estação chuvosa, as E tiveram DH maior que as NE $\left(\mathrm{U}_{2016-2017}=392359,5 ; \mathrm{U}_{2017-2018}=522316,5 ; \mathrm{p}=0,000\right)$. Já na estação seca, o DH foi maior nas NE que nas $\mathrm{E}\left(\mathrm{U}_{2017}=910375,0 ; \mathrm{U}_{2018}=551183,0 ; \mathrm{p}\right.$ $=0,000)$.

Os valores encontrados para os $\mathrm{DH}$ de cada localidade foram testados quanto a correlação com o número de carrapatos encontrado sobre os pequenos mamíferos, porém não foi encontrada correlação significativa $\left(r_{s}=0,029, p=0,956\right)$ (figura 14). 
Tabela 9: Variáveis da estrutura do habitat avaliadas nas áreas endêmicas antropizadas (E) e não endêmicas mais antropizadas (NE) do estado de São Paulo, entre 2016 e 2018

\begin{tabular}{|c|c|c|c|c|c|c|c|c|c|c|c|c|c|c|}
\hline & \multicolumn{2}{|c|}{ Cobertura do dossel (\%) } & \multicolumn{2}{|c|}{ Peso da serrapilheira $(\mathrm{g})$} & \multicolumn{2}{|c|}{$\begin{array}{l}\text { Altura da serrapilheira } \\
\qquad(\mathrm{cm})\end{array}$} & \multicolumn{2}{|c|}{$\begin{array}{c}\text { Sub-bosque } \\
\text { (complexidade até } 2 \mathrm{~m} \text { ) }\end{array}$} & \multicolumn{2}{|c|}{$\begin{array}{c}\text { Sub-bosque }\left(\mathrm{n}^{\circ} \mathrm{de}\right. \\
\text { plantas acima de } 50 \mathrm{~cm} \text { e } \\
\text { dap }<14 \mathrm{~cm})\end{array}$} & \multicolumn{2}{|c|}{$\begin{array}{l}\text { Número de } \\
\text { regenerantes }\end{array}$} & \multicolumn{2}{|c|}{$\begin{array}{c}\text { Valores DAP }>15 \\
(\mathrm{~cm})\end{array}$} \\
\hline & $\mathrm{E}$ & $\mathrm{NE}$ & $\mathrm{E}$ & $\mathrm{NE}$ & $\mathrm{E}$ & $\mathrm{NE}$ & $\mathrm{E}$ & $\mathrm{NE}$ & $\mathrm{E}$ & $\mathrm{NE}$ & $\mathrm{E}$ & $\mathrm{NE}$ & $\mathrm{E}$ & $\mathrm{NE}$ \\
\hline Média & 64,48 & 52,60 & 788,52 & 894,35 & 4,14 & 3,82 & 14,58 & 21,24 & 129,06 & 220,20 & 124,79 & 219,37 & 13,50 & 11,40 \\
\hline $\begin{array}{l}\text { Desvio } \\
\text { Padrão }\end{array}$ & 25,61 & 29,33 & 580,59 & 754,39 & 4,45 & 1,73 & 9,65 & 11,69 & 88,16 & 207,46 & 72,39 & 217,00 & 13,60 & 7,10 \\
\hline Mediana & 68,00 & 57,00 & 673,00 & 667,50 & 3,50 & 4,00 & $14,00^{\mathrm{a}}$ & $20,00^{\mathrm{b}}$ & 116,50 & 162,50 & 121,00 & 136,50 & 9,30 & 9,20 \\
\hline $1 \mathrm{q}$ & 56,00 & 31,00 & 580,59 & 386,25 & 2,87 & 3,00 & 8,00 & 12,25 & 64,50 & 93,25 & 76,50 & 91,25 & 6,05 & 7,01 \\
\hline $3 q$ & 84,00 & 77,50 & 955,00 & 1150,00 & 5,00 & 5,00 & 20,00 & 29,00 & 152,75 & 271,50 & 155,25 & 305,00 & 14,97 & 12,90 \\
\hline Mín. & 0,00 & 0,00 & 0,00 & 0,00 & 0,00 & 0,00 & 0,00 & 0,00 & 0,00 & 3,00 & 0,00 & 3,00 & 3,70 & 4,80 \\
\hline Máx. & 99,00 & 96,00 & 4800,00 & 4000,00 & 53,50 & 10,00 & 47,00 & 53,00 & 359,00 & 778,00 & 334,00 & 778,00 & 76,80 & 51,00 \\
\hline
\end{tabular}

Letras minúsculas diferentes indicam diferença significativa $(\mathrm{p}<0,05)$ entre áreas endêmicas $(\mathrm{E})$ e não-endêmicas $(\mathrm{NE})$ 
Tabela 10: Déficit hídrico calculado para as áreas E e NE

\begin{tabular}{|c|c|c|}
\hline \multirow[b]{2}{*}{ Período } & \multicolumn{2}{|c|}{ DH (média, mínimo-máximo) em mmHg } \\
\hline & Áreas endêmicas antropizadas & $\begin{array}{l}\text { Áreas não-endêmicas mais } \\
\text { antropizadas }\end{array}$ \\
\hline Verão 2016-2017 & $1,98(0,35-4,26)$ & $0,14(0-3,84)$ \\
\hline Seca 2017 & $0,84(0,00-2,47)$ & $1,01(0,00-2,19)$ \\
\hline Verão 2017-2108 & $0,85(0,00-3,15)$ & $0,66(0,00-2,46)$ \\
\hline Seca 2018 & $0,96(0,00-2,68)$ & $0,74(0,00-1,35)$ \\
\hline
\end{tabular}

Figura 14: Correlação entre DH de cada localidade e número de carrapatos sobre pequenos mamíferos

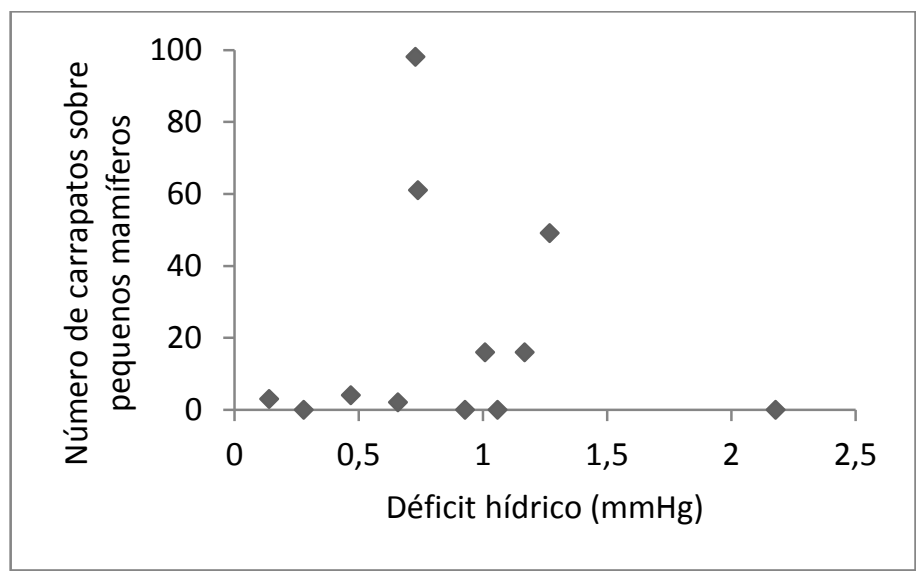




\section{Discussão}

A comunidade de pequenos mamíferos, importantes hospedeiros para estágios imaturos de muitas espécies de carrapatos (OLIVER 1989, GUGLIELMONE e NAVA 2010), afeta diretamente a ixodofauna de um dado local. Em nosso estudo, o número de espécies de pequenos mamíferos foi muito similar entre os três tipos de áreas, mas a abundância de algumas espécies variou, assim como a própria composição da comunidade. Nesse sentido, os ambientes E parecem ser compostos por espécies mais comuns, com maior número de indivíduos de poucas espécies, principalmente do gambá de orelha branca, D. albiventris. As NE também apresentaram dominância por esse marsupial, porém, houve maior equilíbrio na abundância das demais espécies. Além disso, espécies exclusivas das áreas NE e BIO são menos comuns que aquelas exclusivas registradas nas E. Por exemplo, nessas últimas, o roedor M. musculus está fortemente associado a ambientes antropizados (SCHEIBLER e CHRISTOFF, 2007; GOMEZ e PROVENSAL, 2008).

A maior taxa de captura na seca é comumente registrada em estudos com pequenos mamíferos em áreas de Cerrado (VIEIRA, 2002; ALHO, 2003; SANTOS-FILHO et al., 2008) ou mesmo áreas mais degradadas (SCHEIBLER e CHRISTOFF, 2007). Sendo assim, já era esperado que isso ocorresse, ao menos nas E e NE. Nas BIO isso também foi observado, mas essas áreas são compostas por formações savânicas, provavelmente obedecendo, assim, a esse padrão. Uma provável explicação para essa maior taxa de captura durante a seca seria a de que, em épocas de menos recursos, os animais exploram mais intensamente o ambiente, aumentando a chance de captura.

A maior ocorrência de carrapatos também foi observada durante o período mais seco, com dominância de estágios imaturos. Esse padrão é frequentemente encontrado para o gênero Amblyomma no sudeste e no Pantanal (LABRUNA et al. 2002, RAMOS et al. 2016, SERRA-FREIRE et al., 1982).

A prevalência de parasitismo nos pequenos mamíferos registrada nas $\mathrm{E}$ foi maior do que as registradas nas $\mathrm{NE}$ e nas $\mathrm{BIO}$, uma vez que o número de carrapatos coletados nas $\mathrm{E}$ foi muito superior do que nas demais áreas, sendo esse número 2,2 vezes o das $\mathrm{NE}$ e 8,2 vezes o das BIO. Esse fator talvez esteja relacionado a um grande número de carrapatos presente no ambiente, ambientes degradados e com alto grau de antropização (SZABÓ et 
al., 2009) e áreas endêmicas para FMB (BRITES-NETO et al., 2013; LUZ et al. manuscrito submetido) registram altas densidades na população de carrapatos.

O carrapato mais abundante nas $\mathrm{E}$ foi $A$. sculptum enquanto nas NE foi $A$. dubitatum, assim como no trabalho realizado por Luz e colaboradores (2019, manuscrito submetido) em áreas semelhantes. Esses carrapatos se concentraram na espécie hospedeira mais frequente, $D$. albiventris que foi o pequeno mamífero mais capturado nas áreas mais antropizadas e possuiu o maior número de carrapatos em parasitismo dentre os hospedeiros vistoriados.

O número de capturas desse marsupial foi praticamente igual nos dois conjuntos de áreas mais antropizadas, sendo 66 nas E e 67 nas NE, assim, a abundância desse hospedeiro parece não explicar as diferenças nos números de carrapatos de cada espécie presente nessas áreas. Além disso, no total, o número de carrapatos nas $\mathrm{E}$ foi bem maior que nas NE e nas BIO. Nas BIO A. sculptum foi dominante, mas concentrado em uma só espécie (D. azarae), e em apenas quatro indivíduos. Considerando as demais espécies de carrapatos, mais frequentes, a dominante foi A. parvum, já relatado como sendo bastante comum nas áreas de estudo, principalmente sobre equimídeos (RAMOS, 2013; RAMOS et al. 2014, CANÇADO et al. 2008). A contribuição de outras espécies de pequenos mamíferos para A. sculptum, no que se refere às taxas de infestação observadas, não foi relevante em áreas endêmicas e não endêmicas com alto grau de antropização. Em áreas endêmicas onde a transmissão de $R$. rickettsii ocorre através da picada de A. sculptum, gambás estão entre os animais considerados bons sentinelas, juntamente aos cães e aos cavalos (HORTA et al. 2007, SANGIONI et al. 2005).

Os resultados nos levam a supor que a inversão da dominância entre espécies de carrapatos, associada ao desequilíbrio populacional desses artrópodes (caracterizado pelo número muito elevado de carrapatos nas E), estejam entre os fatores diferenciais mais importantes para a ocorrência ou não de FMB nas áreas estudadas. Essa diferença numérica foi constatada, nas áreas de estudo, em trabalho complementar e concomitante ao presente estudo, no qual se avaliou a ocorrência de carrapatos em vida livre, pelas técnicas de arraste e gelo seco, e em parasitismo sobre capivaras (LUZ et al., 2019 dados não publicados). Essa constatação não explica, porém, quais as causas para a configuração de tais cenários. Uma hipótese seria de que o ambiente para os carrapatos vetores sejam favorecidos nas E, uma vez que existem diferenças comportamentais e requisitos 
fisiológicos importantes e dependentes de condições ambientais específicas que diferem entre A. sculptum e, por exemplo, A. dubitatum (QUEIROGAS et al., 2012; RAMOS et al., 2017; PAJUABA-NETO et al., 2018).

A seca é época de pico das ninfas (LABRUNA et al., 2002; LABRUNA et al., 2009b). As áreas não endêmicas apresentaram déficit hídrico maior que nas áreas endêmicas; isso poderia gerar maior mortalidade desse estágio de vida dos carrapatos, que é mais sensível a dessecação que os adultos (PERRET et al., 2004). Essa suposta mortalidade poderia auxiliar na regulação da população de carrapatos, que é menor nessas áreas. Entretanto, os valores do déficit hídrico em ambos os tipos de área são aparentemente baixos em relação aqueles em que parece ocorrer dano a esses artrópodes (FIELDEN \& RECHAV, 1996, STREY et al. 1996). Esses valores são ainda escassos na literatura e ainda mais raros em se tratando de associações com ixodofauna no hemisfério sul. De qualquer modo, seria necessário avaliar essa relação mais profundamente.

Não houve correlação entre déficit hídrico e número de carrapatos em parasitismo sobre pequenos mamíferos. Entretanto, é preciso enfatizar que, mesmo que a variação desse índice nas áreas estudadas (apesar de diferente entre E e NE) seja suficientemente alta para causar algum efeito na população de carrapatos, talvez um melhor descritor para tal efeito fosse a infestação ambiental, e não nos animais.

A complexidade do sub-bosque, com a presença marcante de lianas e cipós robustos, foi maior nas NE que nas E. Supõe-se que essas partes vegetais pudessem ser importantes como substrato para deslocamento de pequenos mamíferos, como marsupiais ou roedores arborícolas, apesar de o número de D. albiventris - o principal hospedeiro para carrapatos de forma geral e para o vetor da FMB, A. sculptum - ter sido similar entre E e NE.

A prevalência geral para títulos de anticorpos anti-riquétsias foi praticamente o dobro nas E em relação às NE e quase quatro vezes às BIO. Das amostras testadas que apresentaram reação cruzada entre os diferentes antígenos, o provável antígeno responsável pela resposta sorológica foi detectado para 53 animais, sendo $30(56,6 \%)$ do grupo dos didelfídeos. Dentre as amostras com provável antígeno detectado foi possível notar uma prevalência de $R$. bellii nas NE e nas BIO em detrimento às riquétsias do Grupo 
da Febre Maculosa, alcançando títulos de até 1:8192 nas NE e 1:16384 nas BIO. Os títulos para os antígenos do GFM não ultrapassaram 1:1024 nas amostras em que estes foram determinados como causadores da infecção em ambas as áreas. Já nas $\mathrm{E}$ houve um equilíbrio entre os prováveis antígenos causadores da resposta sorológica, com títulos de até 1:16384 para riquétsias do GFM e de 1:4096 para $R$. bellii.

A prevalência de $R$. bellii como provável antígeno homólogo nas NE está provavelmente associada a predominância de A. dubitatum nessas localidades. Sabe-se que esses carrapatos possuem alta taxa de infecção para esta espécie de riquétsia em ambiente natural (HORTA et al., 2007; PACHECO et al., 2009; BRITES-NETO et al., 2013). Nas BIO a circulação de $R$. parkeri possivelmente está associada a presença e ao parasitismo por A. ovale nos pequenos mamíferos (WITTER et al., 2016). Porém, a presença de Amblyomma triste nessas áreas (LUZ et al. 2019, manuscrito submetido) também pode justificar a circulação desse agente nessa população de pequenos mamíferos, uma vez que essa espécie de carrapato é encontrada infectada naturalmente com $R$. parkeri (MELO et al., 2015) e que pequenos roedores podem ser importantes hospedeiros para seus estágios imaturos (LABRUNA et al., 2003)

Em trabalho realizado com pequenos mamíferos do cerrado de Minas Gerais, Coelho e colaboradores (2016) relataram taxa de soroprevalência para Rickettsia spp. de 13,8\% para os roedores, semelhante aos resultados encontrados nas NE do presente estudo. Já com relação aos marsupiais, os mesmos pesquisadores encontraram taxa mais elevada de sororreatividade $(39,6 \%)$, porém ficando abaixo do descrito no presente trabalho. Ogrzewalska e colaboradores (2012) descreveram resultados semelhantes em trabalho realizado em áreas endêmicas e não endêmicas para FMB na região metropolitana de São Paulo, em que $21,2 \%$ dos soros de roedores e 13,6\% dos soros de marsupiais testados reagiram para pelo menos um antígeno de Rickettsia, estando esses valores entre os encontrados no presente estudo.

As análises moleculares dos tecidos e sangue resultaram em apenas uma amostra (de baço da espécie Gracilinanus agilis) positiva sequenciada, de uma das áreas endêmicas, 100\% idêntica a Rickettsi felis (MG952933.1). Não foram coletados ectoparasitas de nenhuma espécie sobre este marsupial a época da coleta. A presença de agentes do gênero Rickettsia em tecidos e sangue só é detectável no período de riquetsemia, que geralmente tem curta duração, dias ou até semanas em algumas espécies, 
sendo assim algo raro de acontecer (BURGDORFER, 1989). Algumas espécies de artrópodes são consideradas vetores e reservatórios potenciais para $R$. felis, sendo Ctenocephalides felis, a pulga do cão e do gato, a principal delas (REIF and MACALUSO, 2009; ANGELAKIS et al., 2016). Epidemiologia, ciclo de transmissão e patogenicidade dessa bactéria nos hospedeiros vertebrados ainda são desconhecidos; (ANGELAKIS, 2016.). O animal

Houve um maior número de amostras de carrapatos PCR-positivas nas áreas BIO (quase 50\%) que nas áreas mais antropizadas e, dentre estas, mais positivos nas áreas $\mathrm{NE}$ (24\%) que nas E (13\%). Infelizmente não foi possível sequenciar todas essas amostras para determinar com qual espécie de riquétsia eram mais similares. Apenas cinco amostras amplificadas puderam ser sequenciadas, sendo que houve predomínio de sequências mais similares à $R$. bellii nas áreas mais antropizadas, mesmo nas áreas endêmicas.

Não foi detectada nenhuma sequência similar àquelas do GFM nas E, e nenhuma proveniente do carrapato vetor, A. sculptum. Pelo contrário, nessas áreas, somente duas amostras foram sequenciadas resultando em $R$. bellii (carrapatos A. dubitatum, coletados em $R$. rattus e D. albiventris). Nessas áreas 63\% das amostras de carrapatos testadas na PCR eram compostas por A. sculptum, e essa espécie de carrapato possui taxas de infecção por $R$. rickettsii em condições naturais de menos de 1\% (GUEDES et al., 2011, KRAWCZAK et al., 2014; LABRUNA et al.,2017), o que pode explicar o fato de apenas duas dessas amostras serem positivas na PCR real time e nenhuma sequencia dessa espécie ter sido gerada. Além disso, amostras de A. dubitatum representaram $28 \%$ das amostras testadas e, destas, 38,7\% foram positivas na pesquisa do gene gltA, gerando duas sequências de $R$. belli. Conforme mencionado, essa espécie de carrapato possui alta taxa de infecção para esta espécie de riquétsia (HORTA et al., 2007; PACHECO et al., 2009; BRITES-NETO et al., 2013).

Nas NE, apenas um sequenciamento foi possível, resultando em $R$. bellii (Ixodes $\mathrm{sp}$ em Gracilinanus microtarsus). A presença desse agente foi relatada infectando espécies de carrapatos do gênero Ixodes em áreas endêmicas e não endêmicas no estado de São Paulo (HORTA et al., 2006; HORTA et al.,2007).

Já nas $\mathrm{BIO}$, as amostras sequenciadas resultaram em riquétsias diferentes, sendo uma em R. amblyommatis (A. sculptum em D. azarae) e uma em 'Candidatus R. andeanae' 
(A. parvum em T. pachyurus). Amostras compostas de A. parvum representaram 41,6\% do total das testadas provenientes destas localidades, dessas, 93,3\% foram positivas na PCR real time. Nieri-Bastos e colaboradores (2014) relataram altas taxas de infecção por riquétsias nessa espécie de carrapato $(63,5 \%)$, ficando, porém, abaixo da taxa encontrada no presente estudo. A espécie 'Candidatus R. andeanae' é frequentemente encontrada infectando carrapatos A. parvum no Brasil (PACHECO et al., 2007; NIERI-BASTOS et al., 2014; COSTA et al., 2017). Já amostras compostas de A. sculptum representaram 33,3\% das testadas nessas áreas; carrapatos dessa espécie têm sido encontrados infectados por $R$. amblyommatis fporém sempre em baixas frequências como no presente estudo (NUNES et al., 2015; BITENCOURTH et al., 2017; BARBIERI et al., 2019). 


\section{Conclusões}

A composição das comunidades de hospedeiros diferiu entre os três tipos de área, principalmente entre mais antropizadas, que possuíam espécies mais comuns, e menos antropizadas, que possuíam um maior número de espécies diferentes. A ixodofauna também diferiu entre as áreas, tanto em composição (áreas NE apresentaram maior número de espécies em detrimento as demais áreas), quanto em abundância (áreas $\mathrm{E}$ apresentaram número de carrapatos muito superior que demais áreas). A. sculptum foi mais abundante nas áreas endêmicas, e seu principal hospedeiro nas áreas mais antropizadas foi o gambá (D. albiventris) diferentemente das menos antropizadas, que foi a cutia (G. cuja). O gambá foi tão abundante nas $\mathrm{E}$ quanto nas NE, enquanto $A$. sculptum foi abundante somente nas E, sendo substituído por A. dubitatum nas NE. Assim, a presença desse mamífero parece não influenciar a inversão dessas espécies de carrapato entre as duas áreas. A prevalência dos títulos de anticorpos anti-riquétsias foi praticamente o dobro nas $\mathrm{E}$ em relação às NE e quase quatro vezes às $\mathrm{BIO}$ sendo possível notar uma prevalência de $R$. bellii nas NE e nas BIO e um equilíbrio entre os prováveis antígenos causadores da resposta sorológica nas E. Houve um maior número de amostras de carrapatos PCR-positivas nas áreas BIO que nas áreas mais antropizadas. Não foi detectada nenhuma sequência similar àquelas do GFM nas E, e nenhuma proveniente do carrapato vetor, A. sculptum. 


\section{Bibliografia}

ALHO, C.J.R. Conservação da biodiversidade da Bacia do Alto Paraguai: Monitoramento da fauna sob impacto ambiental. MS, Ed.UNIDERP, Campo Grande, 2003.

AMERICANA. 2019. Departamento de Água e Esgoto de Americana - Plano de Saneamento de Americana. Disponível em: americana.sp.gov.br. Acessado em 27 de março de 2019.

ANGELAKIS, E.; MEDIANNIKOV, O.; PAROLA, P.; RAOULT, D. Rickettsia felis: The Complex Journey of an Emergent Human Pathogen. Trends in Parasitology, Vol. 32, No. 7, July 2016.

ARAGÃO, H.B. \& FONSECA, F. Notas de Ixodologia. VIII. Lista e chave para os representantes da fauna ixodológica brasileira. Memórias do Instituto Oswaldo Cruz, 59 : 115-130, 1961.

BARBIERI, A.R.M.; SZABÓ, M.P.J.; COSTA, F.B.; MARTINS, T.F.; SOARES, H.S.; PASCOLI, G.; TORGA, K.; SARAIVA, D.G.; RAMOS, V.N.; OSAVA, C.; GERARDI, M.; DIAS, R.A.; MORAES, E.A. Jr, FERREIRA, F.; CASTRO, M.B.; LABRUNA, M.B. Species richness and seasonal dynamics of ticks with notes on rickettsial infection in a Natural Park of the Cerrado biome in Brazil. Ticks Tick Borne Dis. 10, 442-453, 2019.

BARROS-BATTESTI, D.M., ARZUA, M.\& BECHARA, G.H. Carrapatos de importância médico-veterinária da região neotropical: um guia ilustrado para identificação de espécies. Vox/ICTTD-3/Butantan, São Paulo, São Paulo. 223 p., 2006.

BEATI, L.; PATEL, J.; LUCAS-WILLAMS, H.; ADAKAL, H.; KANDUMA, E.G.; TEMPO-MWASE, E.; KRECEK, R.; MERTINS, J.W.; ALFRED, J.T.; KELLY, S.; KELLY, P. Phylogeography and demographic history of Amblyomma variegatum (Fabricius) (Acari:Ixodidae), the tropical bont tick. Vector-borne and Zoonotic Diseases, v. 12, n. 6, p. 514-525, 2012.

BITENCOURTH, K.; AMORIM, M.; DE OLIVEIRA, S.V.; CAETANO, R.L.; VOLOCH, C.M.; GAZÊTA, G.S. Amblyomma sculptum: genetic diversity and rickettsias in the Brazilian Cerrado biome. Medical and Veterinary Entomology, v. 31, n. 4, p. 427-437, 2017.

BONVICINO, C. R. Guia dos Roedores do Brasil, com Chaves para Gêneros Baseados em Características Externas. Rio de Janeiro: Centro Pan-Americano de Febre AftosaOPAS/OMS. 2008. 
BRASIL, Ministério da Saúde/SVS - Sistema de informação de Agravos de Notificação Sinan Net. Acessado em 3 de julho de 2019.

BRITES-NETO, J.; NIERI-BASTOS, F.A.; BRASIL, J.; DUARTE, K.M.R.; MARTINS, T.F.; VERÍSSIMO, C.J.; BARBIERI, A.R.M.; LABRUNA, M.B. Environmental infestation and rickettsial infection in ticks in a Brazilian spotted fever endemic area. Revista Brasileira de Parasitologia Veterinária, v. 22, n. 3, p. 367-372, 2013.

BURGDORFER, W. Ecological and epidemiological considerations of Rock Mountain spotted fever and scrub typhus. In: WALKER, D.H. (Ed.) Biology of rickettsial diseases. Boca raton: CRC Press, v. 1, p. 34-47, 1989.

CANÇADO, P.H.; PIRANDA, E.M.; MOURÃO, G.M.; FACCINI, J.L.H. Spatial distribution and impact of cattle-raising on ticks in the Pantanal region of Brazil by using the $\mathrm{CO}_{2}$ tick trap. Parasitol Res., Jul;103(2):371-7, 2008. doi: 10.1007/s00436-008-0982-8.

CHAPMAN, C.A.; WRANGHAM R.; CHAPMAN, L.J.; KEVIN, H.; GEBO, D.; GARDNER, L. 1992. Estimators of fruit abundance of tropical trees. Biotropica, 24: 527531.

COELHO, M.G.; RAMOS, V.N.; LIMONGI, J.E.; LEMOS, E.R.S.; GUTERRES, A.; COSTA NETO, S.F.; ROZENTAL T.; BONVICINO, C.R.; D’ANDREA, P.S.; MORAESFILHO, J.; LABRUNA, M.B.; SZABÓ, M.P.J. Serologic evidence of the exposure of small mammals to spotted-fever Rickettsia and Rickettsia bellii in Minas Gerais, Brazil. $J$ Infect Dev Ctries; 10(3):275-282, 2016.

COSTA, F.B.; COSTA, A.P.; MORAES-FILHO, J.; MARTINS, T.F.; SOARES, H.S.; RAMIREZ, D.G.; DIAS, R.A.; LABRUNA, M.B. Rickettsia amblyommatis infecting ticks and exposure of domestic dogs to Rickettsia spp. in an Amazon-Cerrado transition region of northeastern Brazil. PLOS ONE 12(6): e0179163, 2017.

DE LA FUENTE, J.; ESTRADA-PENA, A.; VENZAL, J.M.; KOCAN, K.M.; SONENSHINE, D.E. Overview: Ticks as Vectors of Pathogens that cause diseases in Humans and Animals. Frontiers in Bioscience. 13: 6938-6946, 2008.

EMBRAPA PANTANAL. [s.d.]. Empresa Brasileira de Pesquisa Agropecuária. Disponível em: embrapa.br/pantanal. Acessado em 2 de abril de 2019. 
EREMEEVA, M.E.; SILVERMAN, D.J. Rickettsia rickettsii infection of the EA.hy 926 endothelial cell line: morphological response to infection and evidence for oxidative injury. Microbiology, v.144, p. 2037-2048, 1998.

ESALQ. 2019. Universidade de São Paulo, Escola Superior de Agricultura "Luiz de Queiroz”. Disponível em: esalq.usp.br. Acessado em 27 de março de 2019.

FEA-RP. 2012. Universidade de São Paulo, Faculdade de Economia, Administração e Contabilidade de Ribeirão Preto. Disponível em: fearp.usp.br. Acessado em 28 de março de 2019.

FERNANDES, I.M.; SIGNOR, C.A.; PENHA, J. Biodiversidade no Pantanal de Poconé. Cuiabá: Centro de Pesquisas do Pantanal. 196p., 2010.

FIELDEN, L.J. \& RECHAV, Y. Survival of six species of African ticks in relation to saturation deficits. Experimental \& Applied Acarology, 20: 625-37, 1996.

FZEA. 2015. Universidade de São Paulo, Faculdade de Zootecnia e Engenharia de Alimentos. Disponível em: fzea.usp.br. Acessado em 27 de março de 2019.

GOMES, L.S. Typho exanthematico de São Paulo. Brasil-Médico, v. 17, n. 52, p. 919-921, 1933.

GOMEZ, M.D.; PROVENSAL, M.C.; POLOP, J.J. Effect of interspecific competition on Mus musculus in an urban area. Journal of Pest Science, 81:235-240, 2008.

GUEDES, E.; LEITE, R.C.; PRATA, M.C.A.; PACHECO, R.C.; WALKER, D.H.; LABRUNA, M.B. Detection of Rickettsia rickettsii, in the tick Amblyomma cajennense in a new Brazilian spotted fever endemic area in the state of Minas Gerais. Memórias do Instituto Oswaldo Cruz, v. 100, n. 8, p. 841-5, dez., 2005.

GUEDES, E.; LEITE, R.C.; PACHECO, R.C.; SILVEIRA, I.; LABRUNA, M.B. Rickettsia species infecting Amblyomma ticks from an area endemic for Brazilian spotted fever in Brazil. Revista Brasileira de Parasitologia Veterinária, 20, 308-311, 2011. http://dx.doi.org/10.1590/S1984-29612011000400009

GUGLIELMONE, A.A.; ESTRADA-PEÑA, A.; MANGOLD, A.J.; BARROSBATTESTI, D.M.; LABRUNA, M.B.; MARTINS, J.R.; VENZAL, J.M.; ARZUA, M.; KEIRANS, J.E. Amblyomma aureolatum (Pallas, 1772) and Amblyomma ovale Koch, 
1844 (Acari: Ixodidae): hosts, distribution and 16S rDNA sequences. Veterinary Parasitology, v. 113, n. 3-4, p. 273-288, 2003.

GUGLIELMONE, A.A.; NAVA, S. Hosts of Amblyomma dissimile Koch, 1844 and Amblyomma rotundatum Koch, 1844 (Acari: Ixodidae). Zootaxa, 2541: 27-49, 2010. HOOGSTRALL, H. Ticks in relation to human diseases caused by Rickettsia species. Annual Review of Entomology, v. 12, p. 377- 420, 1967.

HORAK, I.G.; CAMICAS, J.L.; KEIRANS, J.E. The Argasidae, Ixodidae and Nuttalliellidae (Aari: Ixodida); a world list of valid tick names. Experimental and Applied Acarology. 28: 27-54., 2002.

HORTA, M.C.; LABRUNA, M.B.; SANGIONI, L.A.; VIANNA, M.C.; GENNARI, S.M.; GALVÃO, M.A.; MAFRA, C.L.; VIDOTTO, O.; SCHUMAKER, T.T.; WALKER, D.H. Prevalence of antibodies to spotted fever group rickettsiae in humans and domestic animals in a Brazilian spotted fever endemic area in the state of São Paulo, Brazil: serologic evidence for infection by Rickettsia rickettsii and another spotted fever group Rickttesia. American Journal of Tropical Medicine and Hygiene. 71 (1): 93-97, 2004.

HORTA, M.C.; PINTER, A.; SCHUMAKER, T.T.S.; LABRUNA, M.B. Natural infection, transovarial transmission, and transstadial survival of Rickettsia bellii in the tick Ixodes loricatus (Acari: Ixodidae) from Brazil. Ann. N.Y. Acad. Sci. 1078: 285-290, 2006. doi: 10.1196/annals.1374.053.

HORTA, M.C.; LABRUNA, M.B.; PINTER, A.; LINARDI, P.M.; SCHUMAKER, T.T.S. Rickettsia infection in five areas of the State of São Paulo, Brazil. Memórias do Inatituto Oswaldo Cruz, v. 102, p. 793-801, 2007.

HORTA, M.C.; MORAES-FILHO, J.; CASAGRANDE, R.A.; SAITO, T.B.; ROSA, S.C.; OGRZEWALSKA, M.; MATUSHIMA, E.R.; LABRUNA M.B. Experimental infection of opossums Didelphis aurita by Rickettsia rickettsia and evaluation of the transmission of the infection to ticks Amblyomma cajennense. Vector-Borne and Zoonotic Diseases, v. 9, n. 1, p. 109-117, 2009.

KRAWCZAK, F.S.; NIERI-BASTOS, F.A.; NUNES, F.P.; SOARES, J.F.; MORAESFILHO, J.; LABRUNA, M.B. Rickettsial infection in Amblyomma cajennense ticks and capybaras (Hydrochoerus hydrochaeris) in a Brazilian spotted fever-endemic area. Parasites \& Vectors, 7, 1-7, 2014. https://doi.org/10.1186/1756-3305-7-7

LABRUNA, M.B.; KASAI, N.; FERREIRA, F.; FACCINI, J.L.H.; GENNARI, S.M. Seasonal dynamics of ticks (Acari: Ixodidae) on horses in the state of São Paulo, Brazil. Veterinary Parasitology, 105: 65-77, 2002. 
LABRUNA, M.B.; FUGISAKI, E.Y.M.; PINTER, A.; DUARTE, J.M.B.; SZABÓ, M.P.J. Life cycle and host specificity of Amblyomma triste (Acari: Ixodidae) under laboratory conditions. Experimental and Applied Acarology, v. 30, n. 4, p. 305-316, 2003.

LABRUNA, M.B.; WHITWORTH, T.; BOUYER, D.H.; MCBRIDE, J.L.; CAMARGO, M.A.; CAMARGO, E.P.; POPOV, V.; WALKER, D.H. Rickettsia bellii and Rickettsia amblyommii in Amblyomma ticks from the state of Rondônia, Western Amazon, Brazil. Journal of Medical Entomology, v. 41, p. 1073-1081, 2004a.

LABRUNA, M. B.; WHITWORTH, T.; HORTA, M. C.; BOUYER, D. H.; MCBRIDE, J. W.; PINTER, A.; POPOV, V.; GENNARI, S. M.; WALKER, D. H. Rickettsia species infecting Amblyomma cooperi ticks from an area in the state of Sao Paulo, Brazil, where Brazilian spotted fever is endemic. J. Clin. Microbiol. 42, 90-98, $2004 \mathrm{~b}$.

LABRUNA, M.B.; CAMARGO, L.M.A.; TARRASSINI, F.A.; FERREIRA, F.; SCHUMAKER, T.T.S.; CAMARGO, E.P. Ticks (Acari: Ixodidae) from the state of Rondônia, Western Amazon, Brazil. Systematic and Applied Acarology, v. 10, p. 17-32, 2005.

LABRUNA, M.B.; MATTAR, S.; NAVA, S.; BERMUDEZ, S.; VENZAL, J.M.; DOLZ, G.; ABARCA, K.; ROMERO, L.; SOUSA, R.; OTEO, J.; ZAVALA-CASTRO, J. Rickettsioses in Latin America, Caribbean, Spain and Portugal. Revista MVZ Córdoba. 16 (2): 2435-2457, 2011.

LABRUNA, M.B. Ecology of Rickettsia in South America. Annals of the New York Academy of Sciences. 1166: 156-166, 2009.

LABRUNA, M.B.; TERASSINI, F.A.; CAMARGO, L.M.A. Notes on Population Dynamics of Amblyomma Ticks (Acari: Ixodidae) in Brazil. J. Parasitol., 95(4), p. 10161018, $2009 \mathrm{~b}$.

LABRUNA, M.B. Brazilian spotted fever: the role of capybaras. In: MOREIRA, J.R.; FERRAZ, K.M.P.M.B.; HERRERA, E.A.; MACDONALD, D.W. Capybara: biology, use and conservation of an exceptional neotropical species. Springer Science Business Media: New York, p. 371-383, 2013.

LABRUNA, M.B.; KRAWCZAK, F.S.; GERARDI, M.; BINDER, L.C.; BARBIERI, A.R.M.; PAZ, G.F.; RODRIGUES, D.S.; ARAÚJO, R.N.; BERNARDES, M.L.; LEITE, R.C. Isolation of Rickettsia rickettsii from the tick Amblyomma sculptum from a Brazilian spotted fever-endemic area in the Pampulha Lake region, southeastern Brazil. Veterinary Parasitology: Regional Studies and Reports, 8, 82-85, 2017. 
https://doi.org/10.1016/j.vprsr.2017.02.007

LEMOS-MONTEIRO, J.; FONSECA, A. Typho exantemático de São Paulo: novas experiências sobre a transmissão experimental por carrapatos. Brasil-Médico, v.16, n.48, p. 993-995, 1932.

LEMOS-MONTEIRO, J.; FONSECA, F.; PRADO, A. Typho exantemático de São Paulo: pesquisa sobre a possibilidade de transmissão experimental do vírus oir <Ixodidae>. Brasil-Médico, v.16, n.3, p. 49-53, 1932.

LIMA, V.C.L.; FIGUEIREDO, A.C.; PIGNATTI, M.G.; MODOLO, M. Febre maculosa no município de Pedreira, Estado de São Paulo, Brasil - Relação entre ocorrência de casos e parasitismo humano por ixodídeos. Revista da sociedade Brasileira de Medicina Tropical, v. 28, p. 135-137, 1995.

LIMA, C.L.; SOUZA, S.A.L.; SOLZA, C.E.; VILELA, M.F.G.; SANTOS, M.C.G.; PAPAORDANOU, P.M.O.; DEL GUERCIO, V.M.F.; ROCHA, M.M.M. Situação da febre maculosa na região administrativa de Campinas, São Paulo, Brasil. Cadernos de Saúde Pública, v.19, n. 1, p. 331-334, 2003.

LUZ, H.R.; COSTA, F.B.; BENATTI, H.R.; RAMOS, V.N.; SERPA, M.C.A.; MARTINS, T.F.; ACOSTA, I; RAMIREZ, G.D.; MUÑOZ-LEAL, S.; RAMIREZ-HERNANDEZ, A.; BINDER, L.C.; CARVALHO, M.P.; ROCHA,V.; DIAS, T.C.; SIMEONI, C.L.; BRITES NETO, J.; BRASIL, J.; NIEVAS, A.M.; MONTICELLI, P.; MORO, M.E.; LOPES, B.; AGUIAR, D.M.; PACHECO, R.C.; SOUZA, C.E.; PIOVEZAN, U.; JULIANO, R.; FERRAZ, K.M.; SZABÓ, M.P.J.; LABRUNA, M.B. Epidemiology of capybara-associated Brazilian spotted fever. PloS Neglected Tropical Diseases, 2019 (manuscrito submetido)

MANGOLD, A.J.; BARGUES, M.D.; MAS-COMA, S. Mitochondrial 16s rDNA sequences and phylogenetic relationship of species of Ripicephalus and other tick genera among Metastriata (Acari: Ixodidade). Parasitology Research. 84:478-484, 1998.

MARTINS, T.F.; ONOFRIO, V.C.; BARROS-BATTESTI, D.M.; LABRUNA, M.B. Nymphs of the genus Amblyomma (Acari: Ixodidae) of Brazil: descriptions, redescriptions, and identification key. Ticks Tick-borne Dis. 1, 75-99, 2010.

MARTINS, T.F.; BARBIERI, A.R.M.; COSTA, F.B.; TARRISINI, F.A.; CAMARGO, L.M.A.; PETERKA, C.R.L.; PACHECO, R.C.; DIAS, R.A.; NUNES, P.H.; MARCILI, A.; SCOFIELD, A.; CAMPOS, A.K.; HORTA, M.C.; GUILLOUX, A.G.A.; BENATTI, H.R.; RAMIREZ, D.G.; BARROS-BATTESTI, D.M.; LABRUNA, M.B. Geographical distribution os Amblyomma cajennense (sensu lato) ticks (Parasitiformes: Ixodidae) in 
Brazil, with description of the nymph of A. cajennense (senso stricto). Parasites \& Vectors, v. 9, p. 186, 2016.

MELO, A.S. O que ganhamos 'confundindo' riqueza de espécies e equabilidade em um índice de diversidade? Biota Neotrop., vol. 8, no. 3, Jul./Set. 2008.

MELO, A.L.; ALVES, A.S.; NIERI-BASTOS, F.A.; MARTINS, T.F.; WITTER, R.; PACHECO, T.A.; SOARES, H.S.; MARCILI, A.; CHITARRA, C.S.; DUTRA, V.; NAKAZATO, L.; PACHECO, R.C.; LABRUNA, M.B.; AGUIAR, D.M. Rickettsia parkeri infecting free-living Amblyomma triste ticks in the Brazilian Pantanal. Ticks Tick Borne Diseases, v. 6, n. 3, p. 237-241, 2015.

MORAES-FILHO, J.; PINTER, A.; PACHECO, R.C.; GUTMANN, T.B.; BARBOSA, S.O.; GONZÁLES, M.A.; CECÍLIO, S.R.; LABRUNA, M.B. New epidemiological data on Brazilian spotted fever in an endemic area of the state of São Paulo, Brazil. Vector Borne and Zoonotic Diseases, v.9, n.1, p. 73-78, 2009.

NAVA, S.; BEATI, L.; LABRUNA, M.B.; CÁCERES, A.G.; MANGOLD, A.J.;

GUGLIELMONE, A.A. Reassessment of the taxonomic status of Amblyomma cajennense (Fabricius, 1787) with the description of three new species, Amblyomma tonelliae n. sp., Amblyomma interandinum n. sp. and Amblyomma patinoi n. sp., and reistatement of Amblyomma mixtum Koch, 1844 and Amblyomma sculptum Berlese, 1888 (Ixodida: Ixodidae). Ticks and Tick-borne Diseases. 5 (3): 252-276, 2014.

NIERI-BASTOS, F.A.; LOPES, M.G.; CANÇADO, P.H.D.; ROSSA, G.A.R.; FACCINI, J.L.H.; GENNARI, S.M.; LABRUNA, M.B. Candidatus Rickettsia andeanae, a spotted fever group agent infecting Amblyomma parvum ticks in two Brazilian biomes. Memórias do Instituto Oswaldo Cruz, 109(2), 259-261, 2014.

NUNES, E.D.C.; VIZZONI, V.F.; NAVARRO, D.L.; IANI, F.C.D.M.; DURÃES, L.S.; DAEMON, E.; GAZETA, G.S. Rickettsia amblyommii infecting Amblyomma sculptum in endemic spotted fever area from southeastern Brazil. Mem. Inst. Oswaldo Cruz 110, 1058$1061,2015$.

OGRZEWALSKA, M.; SARAIVA, D. G.; MORAES-FILHO, J.; MARTINS, T. F.; COSTA, F. B.; PINTER, A.; LABRUNA, M. B. Epidemiology of Brazilian spotted fever in the Atlantic Forest, state of São Paulo, Brazil. Parasitology. 139 (10): 1283-1300, 2012.

OLIVER, J.H. Jr. Biology and systematics of ticks (Acari: Ixodida). Annu. Rev. Ecol. Syst., 20:397-430, 1989. 
PACHECO, R.C.; HORTA, M.C.; MORAES-FILHO, J.; ATALIBA, A.C.; PINTER, A.; LABRUNA, M.B. Rickettsial infection in capybaras (Hydrochoerus hydrochaeris) from São Paulo, Brazil: serological evidence for infection by Rickettsia bellii and Rickettsia parkeri. Biomedica, 27, 364-371, 2007.

PACHECO, R. C.; HORTA, M. C.; PINTER, A.; MORAES-FILHO, J.; MARTINS, T. F.; NARDI, M. S.; SOUZA, S.S.A.L.; SOUZA, C.E.; SZABÓ, M.P.J.; RICHTZENHAIN, L.J.; LABRUNA, M.B. Pesquisa de Rickettsia spp. em carrapatos Amblyomma cajennense e Amblyomma dubitatum no Estado de São Paulo. Revista da Sociedade Brasileira de Medicina Tropical, v. 42, n. 3, p. 351-353, 2009.

PAJUABA-NETO, A.A.; RAMOS, V.N.; MARTINS, M.M.; OSAVA, C.F.; PASCOAL, J.O.; SUZIN, A.; YOKOSAWA, J.; SZABÓ, M.P.J. Influence of microhabitat use and behavior of Amblyomma sculptum and Amblyomma dubitatum nymphs (Acari: Ixodidae) on human risk for tick exposure, with notes on Rickettsia infection. Ticks and Tick-borne Deseases, v. 9, n. 1, p. 67-71, 2018. https://doi.org/10.1016/j.ttbdis.2017.10.007

PAROLA, P.; LABRUNA, M.B.; RAOULT, D. Tick-borne rickettsioses in America: unanswered questions and emerging diseases. Currente Infectous Disease Report. 11 (1): 40-50, 2009.

PERRET, J.L.; GUIGOZ, E.; RAIS, O.; GERN, L. Influence of saturation deficit and temperature on Ixodes ricinus tick questing activity in a Lyme borreliosis-endemic area (Switzerland). Parasitol Res, 86: 554-557, 2000

PERRET, J.L; RAIS, O.; GERN, L. Influence of Climate on the Proportion of Ixodes ricinus Nymphs and Adults Questing in a Tick Population. J. Med. Entomol. 41(3): 361$365,2004$.

PINTER, A.; LABRUNA, M.B. Isolation of Rickettsia rickettsii and Rickettsia bellii in cell culture from the tick Amblyomma aureolatum in Brazil. Annals of the New York Academy of Sciences, v. 1078, p. 523-529, 2006.

PIZA, J.T.; MEYER, G.R.; GOMES, L.S. Typho exanthematico de São Paulo. Sociedade Impressora Paulista, São Paulo, 156pp, 1932.

QUEIROGAS, V.L.; DEL CLARO, K.; NASCIMENTO, A.R.T.; SZABÓ, M.P.J.

Capybaras and ticks in the urban areas of Uberlândia, Minas Gerais, Brazil: ecological aspects for the epidemiology of tick-borne diseases. Experimental an Applied Acarology, v. 57, n. 1, p. 75-82, 2012. 
RAMOS, V.D.N. Ecologia da interação entre carrapatos e hospedeiros no Pantanal: o papel do porco monteiro, do gado Nelore e de pequenos mamíferos para a ixodofauna na subregião da Nhecolândia, MS. Tese de doutorado em Ecologia e Conservação de Recursos Naturais UFU, 2013.

RAMOS, V.N.; PIOVEZAN, U.; FRANCO, A.H.; OSAVA, C.F.; HERRERA, H.M.; SZABÓ, M.P.J. Feral pigs as hosts for Amblyomma sculptum (Acari: Ixodidae) populations in the Pantanal, Mato Grosso do Sul. Brazil. Exp Appl Acarol, Nov;64(3):393-406, 2014.

RAMOS, V.N.; PIOVEZAN, U.; FRANCO, A.H.A.; RODRIGUES, V.S.; NAVA, S.; SZABÓ, M.P.J. Nellore cattle (Bos indicus) and ticks within the Brazilian Pantanal: ecological relationships. Experimental and Applied Acarology, 68(2), 227-240, 2016. DOI 10.1007/s10493-015-9991-3.

RAMOS, V.N.; OSAVA, C.F.; PIOVEZAN, U., SZABÓ, M.P.J. Ambush behavior of the tick Amblyomma sculptum (Amblyomma cajennense complex) (Acari: Ixodidae) in the Brazilian Pantanal. Ticks and tick-borne diseases, 8(4), 506-510, 2017.

RAOULT, D.; ROUX, D.H. Rickettsioses as paradigmas of new emerging infections disease. Microbiology Clinical Microbiology Reviews, v. 10, p. 694-719, 1997.

REIS, N. R.; PERACCHI, A. L.; PEDRO, W. A. \& LIMA, I. P. 2006. Mamíferos do Brasil. Londrina: SEMA, 437 p.

REIF, K.E.; MACALUSO, K.R. Ecology of Rickettsia felis: a review. J. Med. Entomol., 46, pp. 723-736, 2009.

ROCHA, V.J.; SEKIAMA, M.L.; GONÇALVES, D.D.; SAMPIERI, B.R.; BARBOSA, G.P.; DIAS, T.C.; ROSSI, H.R.; SOUZA, P.F.P. 2017. Capivaras (Hydrochoerus hydrochaeris) e a presença do carrapato (Amblyomma sculptum) no campus da UFSCARAraras, São Paulo. Cienc. Anim. Bras., Goiânia, v. 18, 1-15, e-44671.

ROSENTHAL, C. Riquetsioses. In: AMATO NETO, V. Doenças Transmissíveis. 3 ed. Editora Savier: São Paulo, p.737-751, 1989.

ROUX, V.; FOURNIER, P.E.; RAOULT, D. 1996. Differentiation of spotted fever group rickettsiae by sequencing and analysis of restriction fragment length polymorphism of PCR-amplified DNA of the gene encoding the protein ompA. Journal of Clinical Microbiology, v. 34, p. 2058-2065. 
SANGIONI, L.A.; HORTA, M.C.; VIANNA, M.C.; GENNARI, S.M.; SOARES, R.M.; GALVÃO, M.A.M.; SCHUMACKER, T.T.S.; FERREIRA, F.; VIDOTTO, O.;

LABRUNA, M.B. Rickettsial infection in animals and brazilian spotted fever endemicity. Emerging Infectious Diseases. 11 (2): 265-270, 2005.

SANTOS-FILHO, M.; DA SILVA, D. J.; SANAIOTTI, T. M. Seasonal variation in richness and abundance of small mammals and in forest structure and arthropod availability in forest fragments, at Mato Grosso, Brazil. Biota Neotropica, vol. 8, no. 1, Jan./Mar, 2008.

SÃO PAULO, Secretaria de Vigilância Epidemiológica. Vigilância Epidemiológica: Agravos. Disponível em: cve.saude.sp.gov.br. Acessado em 3 de julho de 2019.

SARAIVA, D.G.; FOURNIER, G.F.; MARTINS, T.F.; LEAL, K.P.; VIEIRA, F.N.; CÂMARA, E.M.; COSTA, C.G.; ONOFRIO, V.C.; BARROS-BATTESTI, D.M.; GUGLIELMONE, A.A.; LABRUNA, M.B. Ticks (Acari: Ixodidae) associated with small terrestrial mammals in the state of Minas Gerais, southeastern Brazil. Experimental and Applied Acarology. 58 (2): 159-166, 2012.

SCHEIBLER, D.R.; CHRISTOFF, A.U. Habitat associations of small mammals in southern Brazil and use of regurgitated pellets of birds of prey for inventorying a local fauna. Brazilian Journal of Biology, v. 67, n. 4, p. 619-625, 2007

SERRA-FREIRE, N.M.S. Epidemiologia de Amblyomma cajennense: ocorrência estacional e comportamento dos estádios não parasitários em pastagens do Estado do Rio de Janeiro. Arquivos da Universidade Federal Rural do Rio de Janeiro, v. 5, n. 2, p. 187193, 1982. [ Links ]

SILVEIRA, I.; PACHECO, R.C.; SZABÓ, M.P.J.; RAMOS, H.G.C.; LABRUNA, M.B. Rickettsia parkeri in Brazil. Emerging Infectious Diseases, v. 13, n. 7, p. 1111-1113, 2007.

SOARES, J.F.; SOARES, H.S.; BARBIERI, A.R.M.; LABRUNA, M.B. Experimental infection of the tick Amblyomma cajennense, Cayenne tick, with Rickettsia rickettsia, the agent of Rocky Mountain spotted fever. Medical and Veterinary Entomology, v. 26, n. 2, p. 139-51, 2012.

SOUZA, S.S.A.L.; SOUZA, C.E.; RODRIGUES NETO, E.J.; PRADO, A.P. Dinâmica sazonal de carrapatos (Acari: Ixodidae) na mata ciliar de uma área endêmica para febre maculosa na região de Campinas, São Paulo, Brasil. Ciência Rural, v. 36, p. 887-891, 2006. 
SOUZA, C.E.; MORAES-FILHO, J.; OGRZEWALSKA, M.; UCHOA, F.C.; HORTA, M.C.; SOUZA, S.S.L.; BORBA, R.C.M.; LABRUNA, M.B. Experimental infection of capybaras Hydrochoerus hydrochaeris by Rickettsia rickettsii and evaluation of the transmission of the infection to the ticks Amblyomma cajennense. Veterinary Parasitology, v. 161, p. 116-121, 2009.

STEUBER, S.; ABDEL-RADY, A.; CLAUSEN, P. PCR-RFLP analysis: a promising technique for host species identification of blood meals from tsetse flies (Diptera: Glossinidae). Parasitology Research. 97: 247-254, 2005.

STREY, O.F.; TEEL, P.D.; LONGNECKER, M.T.; NEEDHAM, G.R. Surviva 1 an d Water-Balance Characteristics of Unfed Adult Amblyomma cajennense (Acari : Ixodidae ). Journal of medical Entomology, 33(1), 63-73, 1996.

SZABÓ, M.P.J.; LABRUNA, M.B.; GARCIA, M.V.; PINTER, A.; CASTAGNOLLI, K.C.; PACHECO, R.C.; CASTRO, M.B.; VERONEZ, V.A.; MAGALHÃES, G.M.; VOGLIOTTI, A.; DUARTE, J.M.B. Ecological aspects of the free-living ticks (Acari:Ixodidae) on animal trails within Atlantic rainforest in south-eastern Brazil. Annals of Tropical Medicine and Parasitology, v. 103, n. 1, p. 57-72, 2009.

SZABÓ, M.P.J.; PINTER, A.; LABRUNA, M.B. Ecology, biology and distribution of sppoted-fever tick vectors in Brazil. Frontiers in Cellular and Infection Microbiology, v.3, p. 27, 2013.

SZABÓ, M.P.J.; NIERI-BASTOS, F.A.; SPOLIDORIO, M.G.; MARTINS, T.F.; BARBIERI, A.R.M.; LABRUNA, M.B. In vitro isolation from Amblyomma ovale (Acari: Ixodidae) and ecological aspects of the Atlantic rainforest Rickettsia, the causative agent of a novel spotted fever rickettsiosis in Brazil. Parasitology, v. 140, n. 6, p. 719-728, 2013.

TIRIBA, A.C. Geografia médica das riquetsioses. In: LACAZ, C.S.; BARUZZI, R.G.; SIQUEIRA JR, W. Introdução à geografia médica do Brasil. São Paulo: Editora USP (Edgar Blucher Ltda), 568p., 1972.

TIRIBA, A.C.; MONTEIRO, E.V. Riquetsioses. In: VERONESI, R. Doenças infecciosas e parasitárias. 7 ed. Guanabara Koogan: Rio de Janeiro, p. 213-226, 1985.

UFMT. 2016. Universidade Federal do Mato Grosso. Disponível em: ufmt.br. Acessado em 2 de abril de 2019. 
VIEIRA, E.M.; MONTEIRO-FILHO, E.L. Vertical stratification of small mammals in the Atlantic rain forest of south-eastern Brazil. Journal of Tropical Ecology, 19(05): 501-507, 2003

VIEIRA, M.V. Seasonal niche dynamics in coexisting rodents of the Brazilian Cerrado. Studies on Neotropical Fauna and Environment, v. 38, n. 1, p. 7-15, 2002.

VOLTOLINI, J.C.; WLUDARSKI, A.; DA SILVA, I. 2010. Estrutura da vegetação na borda e interior de um fragmento florestal pequeno em área urbana. Revista Biociências, 15(2): 133-138.

WALKER, D.H. Pathology and phatogenesis of the vasculotropic rickettsioses. In:

WALKER, D.H. Biology of rickettsial diseases. Boca Raton, FL:CRC Press, v. 1, p. 115$138,1988$.

WEINERT, L.A.; WERREN, J.H.; AEBI, A.; STONE, G.N.; JIGGINS, F.M. Evolution and diversity of Rickettsia bacteria. BMC Biology, v.7, n. 6, p. 1-15, 2009.

WITTER, R.; MARTINS, T.F.; CAMPOS, A.K.; MELO, A.L.T.; CORREAA, S.H.R.; MORGADO, T.O.; WOLF, R.W.; MAY-JÚNIOR, J.A.; SINKOC, A.L.; STRÜSSMANN, C.; AGUIAR, D.M.; ROSSI, R.V.; SEMEDO, T.B.F.; CAMPOS, Z.; DESBIEZ, A.L.J.; LABRUNA, M.B.; PACHECO, R.C. Rickettsial infection in ticks (Acari: Ixodidae) of wild animals in midwestern Brazil. Ticks and Tick-borne Diseases, v. 7, n. 3, p. 415-423, 2016. 